\title{
Structure-Activity Relationship and Mechanistic Insights for Anti-HIV Natural Products
}

\author{
Ramanpreet Kaur ${ }^{\ddagger}$, Pooja Sharma ${ }^{1,2^{\ddagger}}$, Girish K. Gupta ${ }^{3}$, Fidele Ntie-Kang 4,5,6* and Dinesh Kumar \\ 1* \\ 1 Sri Sai College of Pharmacy, Manawala, Amritsar-143001, Punjab, India; Tel.: +91-9988902489; e-mail: \\ dineshkumargndu@gmail.com \\ 2 Department of Pharmaceuitcal Sciences and Drug Research, Punjabi University, Patiala. e-mail: \\ poojasharmagndu@gmail.com \\ 3 Sri Sai College of Pharmacy, Badhani, Pathankot, Punjab, India. \\ 4 Department of Chemistry, Faculty of Science, University of Buea, P.O. Box 63, Buea, Cameroon; Tel.: +237 \\ 685625811; E-mail: fidele.ntie-kang@ubuea.cm \\ 5 Institute for Pharmacy, Martin-Luther-Universität Halle-Wittenberg, Kurt-Mothes-Str. 3, 06120 Halle \\ (Saale), Germany; Tel.: +49 3455525043; E-mail: ntiekfidele@gmail.com; \\ fidele.ntie-kang@pharmazie-uni-halle.de \\ 6 Department of Informatics and Chemistry, University of Chemistry and Technology, Prague, Technická 5, \\ 16628 Prague 6 Dejvice, Czech Republic; ntiekanf@vscht.cz \\ * These authors contributed equally \\ * Correspondence: ntiekfidele@gmail.com (F.N.K.) and dineshkumargndu@gmail.com (D.K.);
}

\begin{abstract}
Acquired Immunodeficiency Syndrome (AIDS) which is chiefly originated by a retrovirus named Human Immunodeficiency Virus (HIV), has influenced about 70 million populations worldwide. Even though several advancements have been invented in the field of antiretroviral combination therapy, still HIV has become the dominant reason for death in South Africa, for example. The current antiretroviral therapies have achieved success in providing instant HIV suppression but with countless undesirable adverse effects. In the present day, the biodiversity of the plant kingdom is being explored by several researchers for the discovery of potent anti-HIV drugs with different mechanisms of action. The primary challenge is to afford a treatment that is free from any sort of risk of drug resistance and serious side effects. Hence, there is a strong demand to evaluate the drugs obtained from natural plants as well as the synthetic derivatives that have been derived from the natural compounds by various chemical reactions. Several plants such as Andrographis paniculata, Dioscorea bulbifera, Aegle marmelos, Wistaria floribunda, Lindera chunii, Xanthoceras sorbifolia and others have displayed significant anti-HIV activity showing more potent anti-HIV activity along with their structures, SARs \& important key findings.
\end{abstract}

Keywords: AIDS; anti-HIV; natural products; SARs.

\section{Introduction}

The acquired immunodeficiency syndrome (AIDS) is a disease of cell-mediated immune system or T-lymphocytes of the human body. In AIDS, the count of helper T cells gets reduced which directly stimulates the production of antibodies from B cells. As a result, the body's natural defense system against AIDS infection gets destroyed [1]. According to the World Health Organization, about 75 
million individuals have been infected from the human immunodeficiency virus (HIV), and about 37 million people are still fighting with this life-threatening infection. HIV is going to be increased day by day due to illiteracy, unhygienic living pattern, unsafe sexual relationships and lack of awareness [2]. In 1981, AIDS was first observed among homosexuals. The first human retrovirus was founded at the National Cancer Institute, in the USA by Robert Gallo and his colleagues. In 1983, Professor Luc Montagnier along with his co-workers had discovered the AIDS virus at the Institute Pasteur, in Paris [3]. In 1986, the International Committee on Viral Nomenclature firstly named the AIDS virus officially as Human Immunodeficiency Virus (HIV) [4]. It is considered that during the 1960s, the virus of AIDS has come from a monkey host cell into human host cells in Africa. South Africa is also known as "world AIDS capital". In practice, Africans worldwide are additionally stricken by this unwellness than any other race [5].

\subsection{Pathogenesis}

The motor agent for AIDS is an animal retrovirus named HIV that is ready to replicate and integrate its infectious DNA into the host cell's healthy DNA. It's an animal virus that chiefly attacks the body's helper T cells [6, 7]. The virus is spherically shaped, having a diameter of around 90-120 nm. Its genetic material generally contains a single standard RNA fiber metameric into two similar fibers and is connected with an enzyme called reverse transcriptase enzyme. The coating contains a lipid bilayer that is derived from the membrane of the host cells and spikes of glycoprotein that are like projecting knob. It consists of two protein coats as depicted in Figure 1. [8, 9]. Internally, the virus contains a protein layer that is called matrix, which consists of the necessary proteins and nuclear material. The virus also contains an enzyme known as a protease that disintegrates the viral polyproteins to form new functional proteins. Reverse transcriptase is an enzyme that causes the conversion of the viral RNA into viral DNA. Integrase is an enzyme that allows the entry of viral DNA into the host nucleus [10,11].

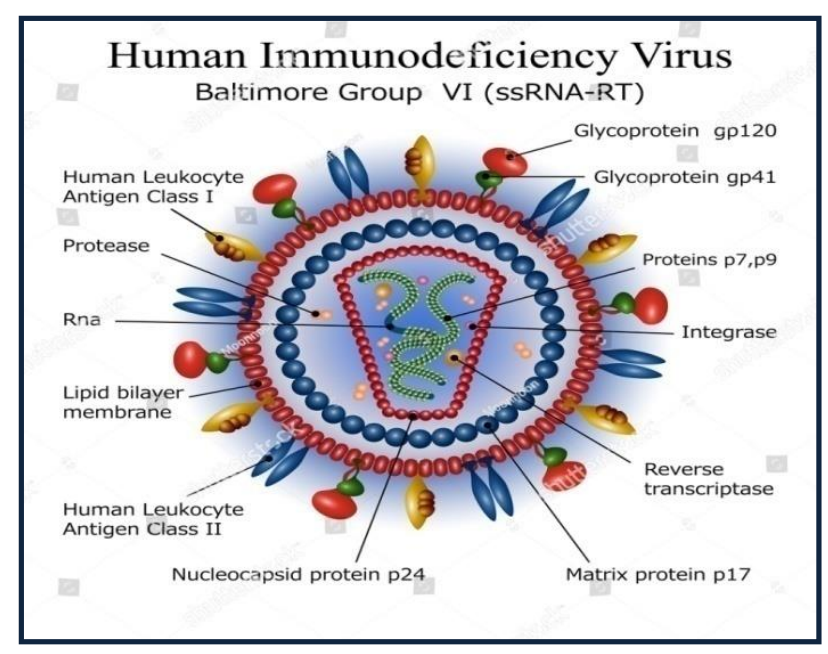

Figure 1. Structure of HIV Virus [8]

\subsection{Replication Cycle of HIV}

The complete HIV replication cycle is represented in Figure 2. After the entrance of the virus into the body of the individual, the virus enters into the body cells through various binding receptors that are depicting on the top of the macrophages, T lymphocytes, dendritic cells and monocytes [6, 7]. To 
enter into the host cell, the virus binds with certain chemokine receptors along with interaction with cell membrane proteins. Inside the host cell, the HIV releases and utilizes its reverse transcriptase enzyme for the synthesis of viral DNA from its viral genome that is HIV RNA. The conversion of viral RNA into DNA allows the virus to enter into the host cell nucleus [10,11]. Inside the nucleus, the HIV releases an enzyme Integrase that helps it to integrate its viral DNA into the host cell's DNA [8- 10]. Newly formed HIV protein and viral RNA shift towards the cell membrane and reunite into immature HIV. The new immature virus (non-infectious) budded off from the host cell. Then, the protease enzyme is released from the viruses that cause the breakdown of long-chain polypeptides of immature virus and the newly formed small protein particles make the new mature viruses that enter into the new host cells for spreading the infection [12,13].

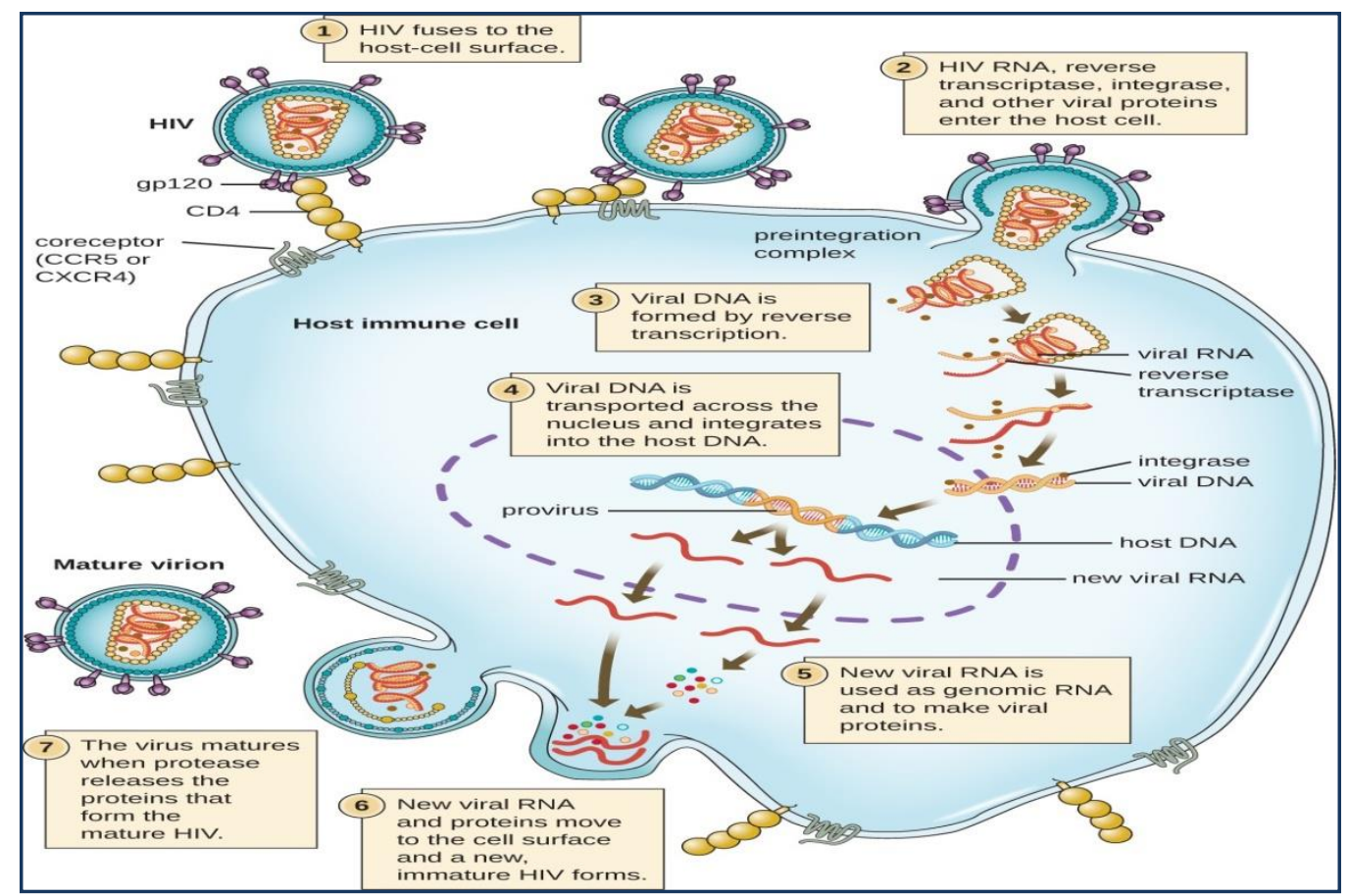

Figure 2: HIV Replication Cycle [6]

\subsection{Diagnosis}

The HIV infection is generally diagnosed from the blood plasma. The diagnosis of the viral infection into the blood of the host is normally estimated from the viral RNA mass. The infection is linked with the period of acute symptoms which include lymphadenopathy, fever, weight loss, lethargy, general malaise, pharyngitis, rashes, nausea, headache, myalgias, anyhow severe consequences like meningitis may also occur [2,6]. While the duration of acute HIV infection, the viral RNA is at the highest levels in the blood plasma and also the symptoms as well as the severity of infection is dependent on the viral mass in the plasma. It is estimated that the amount and characteristics of the virus indicate its pathogenesis as well as the replication. Hence, the clinical details and infection progression are relying on the host characteristics along with the viral genotype [14-16]. ELISA and Western Blotting were the two tests employed for the diagnosis of AIDS in the past. ELISA is used for the detection and measurement of the antibodies that are produced against a specific pathogen [17]. The western blotting test was employed for confirmation of ELISA positive tests. It is used to check the specific proteins in the blood sample. The samples go through the protein denaturation 
and then gel electrophoresis. The combined effect of both the tests is $99 \%$ accurate. At the time, various alternatives are available in place of Western Blotting test which is less time consuming [18].

\subsection{Present Therapy for HIVIAIDS}

Despite the fact, HIV was known within the past 1980s, however, there's no efficacious therapy or vaccine for the entire destruction of HIV [2]. The present therapy for AIDS is quite complex, tedious, requires expertise, solid motivation and patient's commitment, suitable means and is costly. Antiretroviral therapy (ART) is only about twenty years old, and further approaches are still progressing. Many patients are still suffering from this untreated infection. The use of certain medicines can recover the disease quality but cannot promise the life of a patient. However, with the development of new entities and immune modulators, it is possible to fight with this disease [19-21]. The drugs provide a meaningful advancement in mitigation, control, cure and prevention. With the establishment of HAART (highly active antiretroviral therapy) and anti-retroviral agents in 1996 necessarily decreased the mortality and morbidity of AIDS. Antiretroviral therapy is presently prescribed for all adult patients with HIV [2]. A combination of various drugs is given to achieve an efficacious treatment like; nucleoside reverse transcriptase inhibitors, fusion inhibitors, non-nucleoside reverse transcriptase inhibitors, integrase inhibitors, protease inhibitors along with immunomodulators. Because none of the presently accessible regimens can abolish HIV from the body of the patient, the objective of therapy is to durably and maximally prohibit viral replication so that the individual can achieve and maintain adequate immune response against the potential viral pathogens. Higher the abolition of viral replication, lower is the incidence of development of drug-resistant virus. The minimization in the mortality and morbidity of the disorder has turned it from a lethal syndrome to a chronic and controllable situation [5,19,21]. It is now advised that all HIV positive individuals with the perceptible virus, disregarding of their count of CD4 cells, should be dealt with anti-retroviral therapy (ART) quickly after diagnosis, so as to avoid infection progression, promote clinical outcomes in addition to minimizing AIDS-associated incidents, non-AIDS regarding incidents etc [20].

\subsection{Drawbacks of Present Anti-Retroviral Therapy}

Even though it is impressive to deal with all the symptomatic and asymptomatic HIV infected persons, no long-lasting clinical outcomes have been illustrated in asymptomatic patients with acceptable immune competency [22]. Arguments in contrast to early remedies in asymptomatic patients involve dangerous side effects of anti-HIV drugs, their toxicity and destructive effect of anti-HIV drugs on quality of life, principally lipid abnormalities, possibility of drug resistance restricting future treatment opportunities, drug interactions, limited capability of available regimens, failure of treatment, risk of distribution of resistance virus and big cost [23-25]. The right time to start anti-HIV therapy stays uncertain. The antiviral drugs that act on the HIV virus, also affect the host cells; they may harm the host cell's nuclear material also along with the HIV genome. With nucleoside reverse transcriptase inhibitors, toxicity is primarily due to the partial provision of cellular DNA polymerase. Neutropenia and Anaemia are extremely critical and dose-dependent adverse effects [24-26].

\section{Natural Plants as Anti-HIV Agents}


The present treatments are restricted by the evolution of multidrug resistance. That's why novel targets and new more effective drugs are required for achieving the goal of an entire eradication of AIDS. Also, infected cells stay persisted and put a basic barrier to the elimination of HIV-1. From the past 10 years the mechanism by which the virus persists put forward the way for the invention and discovery of new drug compounds that worked efficaciously against HIV without activating the $\mathrm{T}$ cells of the immune system [27, 28]. Since more effective and new drug compounds were still required for the manipulation and control of HIV, it has been recommended by the World Health Organization (WHO) that ethnomedicines and various other natural constituents should be orderly tested in contrast to HIV while they may produce more affordable and durable therapeutic agents $[29,30]$. Interestingly, in the 1990s, a lot of tasks were performed in this field, specifical inventions of natural products with their mechanisms against HIV-1 enzymes like reverse transcriptase, integrase, protease and some fusion inhibitors. The natural drugs have chemical diversity with higher hit rates in High throughput screening and high capability to approach the target site [31]. A number of alkaloids, flavonoids, coumarins, terpenoids, and polyphenolic compounds are investigated to exert anti-HIV activity extracted from various plants [32,33]. From this inspiration Chaniad et al. studied anti-HIV activity from Dioscorea bulbifera [34], Jiang et al. again evaluated Euphorbia sikkimensis for anti-HIV properties [35], Kalvatchev et al. reported that the extracts of Culendula officinalis also shows significant effects against HIV [36], Kapewwangolo et al. described anti-HIV action of Sceletium tortuosum [37], similarly Brazilian propolis, Kadsura lancilimba, Lithocarpus litseifolius, and Ocimum labiatum have also been studied for their anti-HIV properties [38-41].

Keeping in the view that numerous plants having significant anti-HIV properties, therefore, this review highlights the discovery of plant-based compounds/molecules during the last decades that have been used in the treatment/management of HIV. A detailed account of plants according to the mechanism of action and activity of secondary metabolites has been discussed. In addition to the design strategies, structure-activity relationships, mechanistic insights revealed during the biological evaluation, IC50 values and important key findings have also been presented diagrammatically. This assemblage will be of great help for the researchers/academicians working in the area of anti-HIV drugs. The article presents medicinal plants that have been classified into various categories. The classification is given below.

In this review, the natural medicinal plants are described into two categories-

1. Plants according to their mechanism of action,

2. Plants according to the activity of secondary metabolites.

\subsection{Natural plants according to their mechanism of action}

Therapeutic agents derived from medicinal plants may be an encouraging alternative for a number of disorders and conditions [42-48]. Antiviral research, attention is chiefly paid on the compounds which interfere with several steps involved in the HIV replication process. For example, almost all the anti-HIV drugs act against the viral proteins represented by the virus, i.e., protease, integrase, reverse transcriptase, etc [49]. Anti-HIV drugs can be categorized into several classes according to their action on the life cycle of HIV [50]. Hence, different drugs act on these different steps of replication and inhibit the further expansion of virus into the body. A group of researchers reported 
the activities of HIV-PR inhibitors from different plants [51-60]. Primarily, all the anti-HIV drugs are divided into the following categories:
a) Fusion Inhibitors (FI)
b) Reverse Transcriptase Inhibitors (RTI)
c) Integrase Inhibitors (ITI)
d) Protease Inhibitors (PRI)
e) Immunomodulators
f) Antioxidants

\subsubsection{Fusion Inhibitors}

Fusion inhibitors are also known as Entry inhibitors. These are mainly CCR5 co-receptor antagonists which inhibit the binding of HIV surface glycoproteins with the host cell's receptor [61]. Infection is chiefly started by the binding of the viral gp120 to the CD4 cell receptor expressed on the surface of T cells, macrophages and some monocytes. This results in a conformational change which further stimulates the interaction of secondary gp120 with co-receptor CCR5 [62]. Fusion inhibitors prevent the entry of virus into the host cell by inhibiting the fusion of virus particle with the membrane of host cell which is the early first step of virus replication [63].

Phytoconstituents from some plants like, Listeria ovate, Cymbidium hybrid, Hippeastrum hybrid, Epipactis helleborine and Urtica dioica possessing the activities of fusion inhibitors and act against the HIV-1 and HIV-2 [64,65]. Matsuda et al. in 2014 reported an alkaloid Cepharanthine (1) isolated from Stephania cepharantha having anti-HIV and anti tumor activities without exerting any serious side effects. It modifies the plasma membrane fluidity and prevents the viral cell fusion [66]. A diterpene lactone named Andrographolide (2) shown in Figure 3 is obtained from the herb Andrographis paniculata possesses HIV-1 fusion inhibition properties [67-71]. Several derivatives of this compound have been produced synthetically to exert more potent anti-HIV properties [72, 73].<smiles>COc1ccc(C[C@@]2(C)c3cc(Oc4cc(C[C@]5(C)c6c(OC)c(cc7c6OCO7)CCN5C)ccc4Oc4ccccc4)c(OC)cc3CCN2C)cc1</smiles>

Cepharanthine<smiles>C=C1CCC2C(C)(C)C(O)CCC2(C)[C@H]1CC=C1C(=O)OC[C@@H]1O</smiles>

(2) Andrographolide

$\left[\mathrm{IC}_{50}=0.59 \mu \mathrm{M}\right]$

Figure 3. Structure of fusion inhibitors.

\subsubsection{Natural plants as Reverse Transcriptase Inhibitors}


The HIV virus utilizes reverse transcriptase enzyme for conversion of its viral RNA into DNA. RT inhibitors mainly act upon this enzyme and prohibit the very important step of viral replication [74]. A number of natural products have been isolated from natral plants have been derived for their activity against RT [55]. The plants used as reverese transcriptase inhibitors viz; Culendula officinalis, Acacia mellifera, Uvaria angolensis, Hypericum scruglii, Spaganium stoloniferum, Calophyllum brasiliense, Maytenus buchanani, Prunus Africana, Vernonia jugalis, Maytenus senegalensis, Melia azedarach, Calophyllum inophyllum, Lomatium suksdorfii, Coriandrum sativum, Chrysanthemum morifolium and Swertia franchetiana [36, 55-82]. Capryl aldehyde and methyl-n-nonyl ketone obtained from Houttuyniu cordata directly inhibit the RT enzyme [55]. Calanolides A (3) and B (4) [78] have been obtained from the plant Calophyllum inophyllum. Some naphthoquinones such as michellamines A, B and $\mathrm{C}$, were extracted from the plant Ancistrocladus korupensis, exhibited inhibitory activity on the HIV-RT enzyme [83]. From lichen named as Cetraria islandica, a RT inhibitory compound acetogenin protolichensterinic acid is obtained [84]. The compounds mallotochromene (5) and mallotojaponin (6) have been given in Figure 4 and separated from Mallotus japonicas have shown strong inhibition of HIV-RT [85]. Another compound nigranoic acid has been extracted from Schisandra lancifolia, acted effectively on the reverse transcriptase replicative enzyme of HIV [86]. Some other plants showing HIV RT inhibitory property are given in the Table 1.

Table 1. Plant Based Reverse Transcriptase inhibitors

\begin{tabular}{|lllc|}
\hline Category & Plant Species & Chemical Constituents & Reference \\
Terpenoid & Excoecaria agallocha & Phorbol & {$[87]$} \\
Terpenoid & Trypterygium wilfordii & Salaspermic acid & {$[88]$} \\
Terpenoid & Euphorbia myrsinites & 15-O-acetyl-3-O-butanoyl-5-O-propion & {$[89]$} \\
& & yl-7-O-nicotinoylmyrsinol & \\
Terpenoid & Polyalthia suberosa & Suberosol & {$[90]$} \\
Terpenoid & Andrographis paniculata & Dehydroandrographolide succinic acid & {$[91]$} \\
& & monoester & \\
Terpenoid & Glycyrrhiza radix & Glycyrrhizin & {$[92]$} \\
Terpenoid & Cowania Mexicana & Cucurbitacin F & {$[93]$} \\
Terpenoid & Tripterygium wilfordii & Tripterifordin & {$[94]$} \\
Terpenoid & Maprounea Africana & 1 $\beta$-hydroxymaprounic acid 3-p- & {$[95]$} \\
& & hydroxybenzoate & \\
Terpenoid & Szigium claviforum & Betulinic acid, platonic acid & {$[96]$} \\
Terpenoid & Houttuynia cordata & Lauryl aldehyde, capryl aldehyde & {$[97]$} \\
Flavonoid & Chrysanthemum & Acacetin-7-O- $\beta$-galactopyranoside & {$[81]$} \\
& morifolium & & {$[98]$} \\
Flavonoid & Scutellaria baicalensis & Baicalin & {$[99]$} \\
Flavonoid & Buchenavia capitata & Buchenavianine & {$[100]$} \\
Flavonoid & Kummerolvia striata & Apigenin-7-O- $\beta$-D-glucopyranoside & {$[101]$} \\
Coumarin & Calophyllum inophyllum & Inophyllums & {$[80]$} \\
Coumarin & Coriandrum sativum & Coriandrin & {$[79]$} \\
Coumarin & Lomatium suksdorfii & Suksdorfin & \\
Coumarin & Aegle marmelous & Imperatorin, xanthotoxol, xanthotoxin & {$[103]$} \\
\hline
\end{tabular}




\begin{tabular}{|c|c|c|c|}
\hline Tannin & Euphorbia jolkini & Putranjivain A & [104] \\
\hline Tannin & Cornus officinalis & Cornusin A & [105] \\
\hline Tannin & Mallotus repandus & Repandusinic acid & [106] \\
\hline Tannin & Hyssop officinalis & Caffeic acid & [107] \\
\hline Polysaccharide & Thuja occidentalis & Thujone & [108] \\
\hline Polysaccharide & Prunella vulgar & Sulfated polysaccharide & [109] \\
\hline Polysaccharide & Viola yedoensis & Sulfonated polysaccharide & [110] \\
\hline Xanthone & $\begin{array}{l}\text { Tripterospermum } \\
\text { lenceolaum }\end{array}$ & $\begin{array}{l}\text { 1,3,5,6-tetrahydroxyxanthone, } \\
\text { 3,4,5,6-tetrahydroxyxanthone }\end{array}$ & [111] \\
\hline Lignan & Haplophyllum ptilostylum & Ptilostin & [112] \\
\hline Lignan & Schisandra chinensis & Gomisin J & [113] \\
\hline Lignan & Ipomoea cairica & Arctigenin, trachelogenin & [114] \\
\hline Marine origin & Hyatella intestinalis & Hyatellaquinone & [115] \\
\hline Marine origin & Fascaplysinopis reticulate & $\begin{array}{l}\text { Fascaplysin, isodehydroluffariellolide, } \\
\text { Homofascaplysin C }\end{array}$ & [116] \\
\hline- & Toxiclona toxius & Toxiusol & [117] \\
\hline- & Plakortis sp. & Plakinidine A & [118] \\
\hline- & Kelletia kelletii & Kelletinin 1 & [119] \\
\hline- & Buccinulum corneum & Kelletinin A & [120] \\
\hline- & Maprounea Africana & 1 $\beta$-hydroxyaleuritolic acid & [121] \\
\hline
\end{tabular}

The therapeutic compounds obtained from different plants, showing anti-HIV reverse transcriptase activity are named as suksdorfin (7) [79], salaspermic acid (8) [88], cucurbitacin F (9) [93], batulinic acid (10) [96], baicalin (11) [98], buchenavianine (12) [99], thujone (13) [106], hyatellaquinone (14) [115], isodehyroluffariellolide (15) [116], homofascaplysin C (16) [116], toxiusol (17) [117] reperesented in Figure 4. 


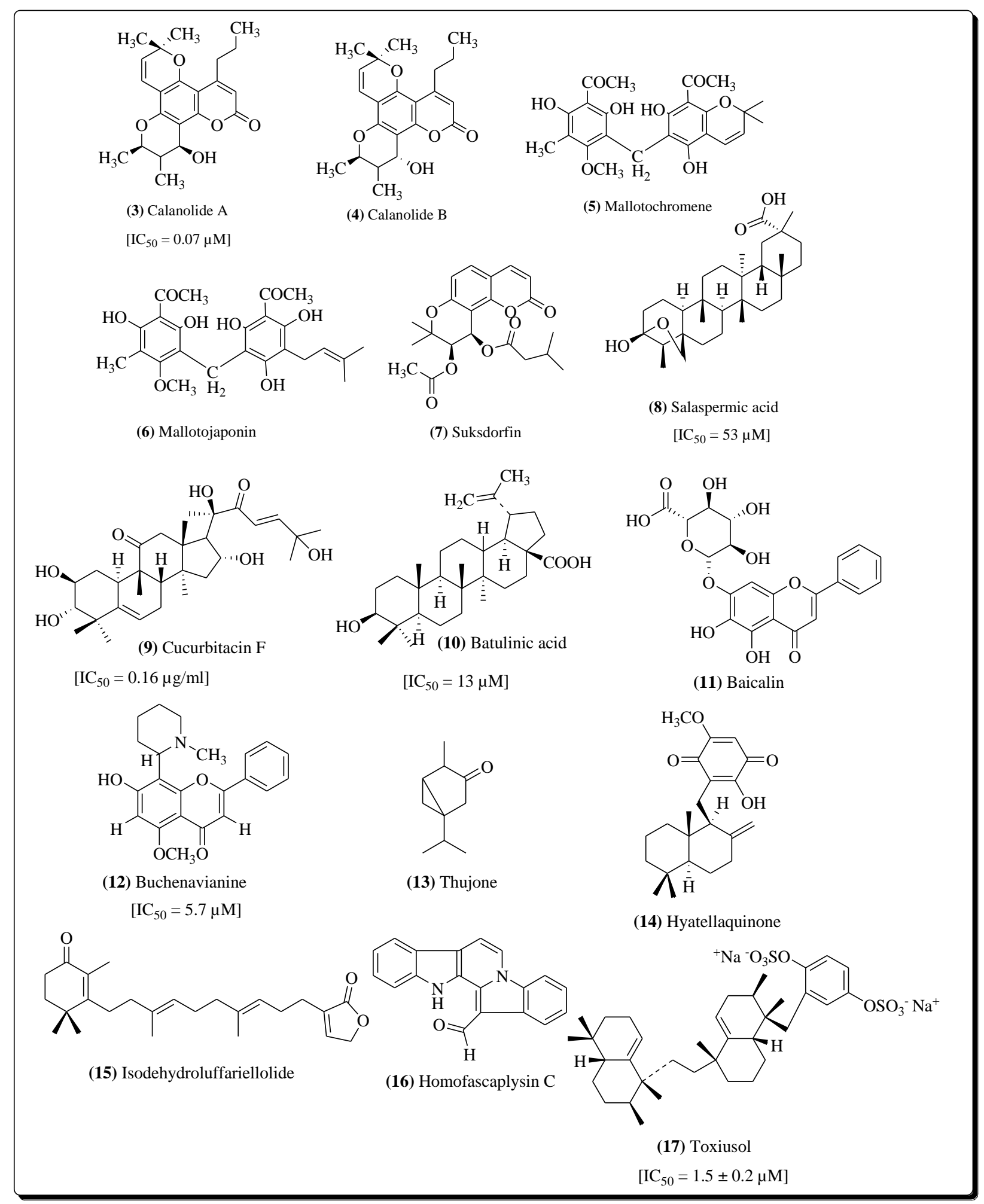

Figure 4. Structure of some potent Reverse Transcriptase Inhibitors.

\subsubsection{Natural plants as Integrase Inhibitors}

The insertion of HIV DNA into the DNA of host cell is generally catalyzed by the integrase enzyme of HIV virus. The reaction is preceded in two phases; the first phase is $3^{\prime}$-processing phase and second phase includes the transfer of strand [122]. Various therapeutic active components have been 
separated from the plant Dioscorea bulbifera. The plant extract has exhibited several therapeutic properties such as; anticancer, antibacterial, analgesic, and antidiabetic [123-127]. Chaniad et al. isolated seven different components have been recognized from the D. bulbifera extract with anti-IT property. Structure of allantoin (18), 5,7,4'- trihydroxy- 2- styrylchromone, 2,4,3',5'tetrahydroxybibenzyl, quercetin 3-O- $\beta$-D -galactopyranoside, 2,4,6,7- tetrahydroxy- 9,10dihydrophenanthrene, quercetin- 3-O- $\beta$-D- glucopyranoside (19) and myricetin (20) shown in Figure 5 [34]. In another study Panthong et al. revealed that Albizia procera is a medicinal plant that has been used in the antiretroviral therapy [128,129]. Catechin (21), suramin and protocatehuic acid (22) are the components identified from the plant extract and are considered to act on the integrase enzyme of HIV virus, hence prohibiting the viral replication [128]. Some ribosome inactivating proteins are considered to act on the integrase enzyme [130]. Currently, a ribosome inactivating protein (RIP) named MAP30, has been extracted from Momordica charantia, has reported to act against the HIV as well as cancer [131,132]. Zhao et al. discovered another RIP trichosanthin, is obtained from the roots of Trichosanthes kirilowii, shown inhibitory activity against integrase enzyme [133]. A number of plant RIPs involving agrostin, saporin, R-momorcharin, gelonin, $\alpha$-momorchain, trichosanthin and luffin have also exhibited an inhibitory effect on the HIV replication [134].

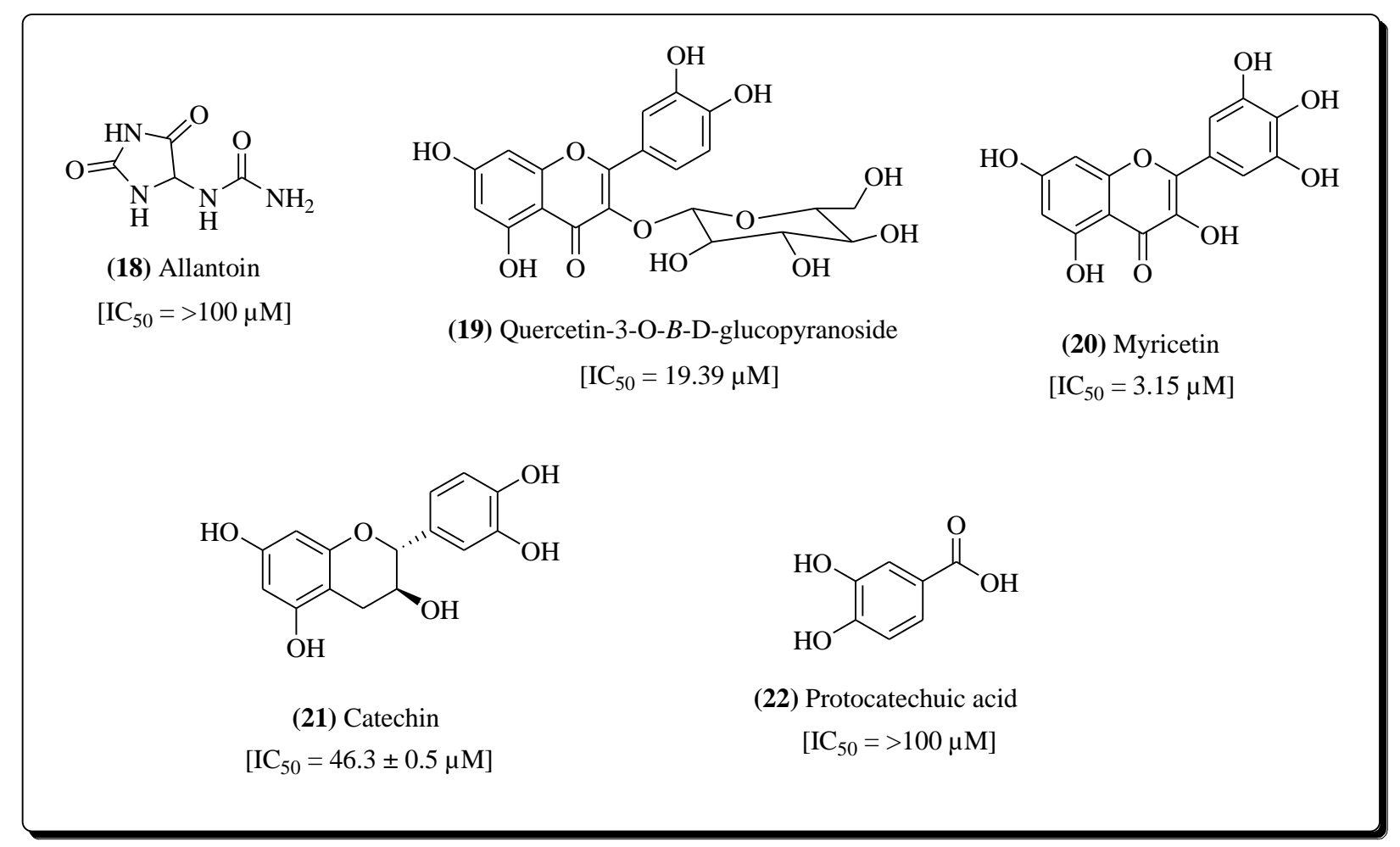

Figure 5. Natural Integrase Inhibitors.

\subsubsection{Natural plants as Protease Inhibitors}

Protease is a viral enzyme that acts at the last step of virus replication. It causes the breakdown of long polypeptides and proteins into the small functional proteins that are generally infectious $[135,138]$. Hence, protease is another target for the antiretroviral therapy and by inhibiting this enzyme the viral replication can be prohibited. Mostly, drugs act on this enzyme preferentially 
[136,138,139]. From Camellia japonica pericarp, plant components camelliatannin A, F and H have been reported that exhibit potent anti-HIV PR inhibitory property [137]. Several Korean therapeutic plants like Viburnum furcatum, IIex cornuta, Berberis amurensis, Lonicera japonica, Chloranthus glaber, Geranium nepalense, Lindera sericea, Wistaria floribunda, Smilax china, Hibiscus hamabo, Lingustrum lucidum, Zanthoxylum piperitum, Styrax obassia, Viola mandshurica, Schisandra nigra and Cocculus trilobus have also been reported potent activity against protease [60]. From the plant stems of Stauntonia obovatifoliola, various components that act on the HIV protease have been extracted such as lupenone (23) [140], 3-O-acetyloleanolic acid (24) [141], resinone (25) [142], lupeol (26) [143] and mesenbryanthemoidgenic acid (27) presented in Figure 6 [144]. In another invention the therapeutic compounds like oleanolic acid (28), dihydromyricetin, epigallocatechin gallate, myricetin [145, 146] and epiafzelechin [147] have been extracted from the wood of plant Xanthoceras sorbifolia has been prooved for the treatment of AIDS [57, 145].

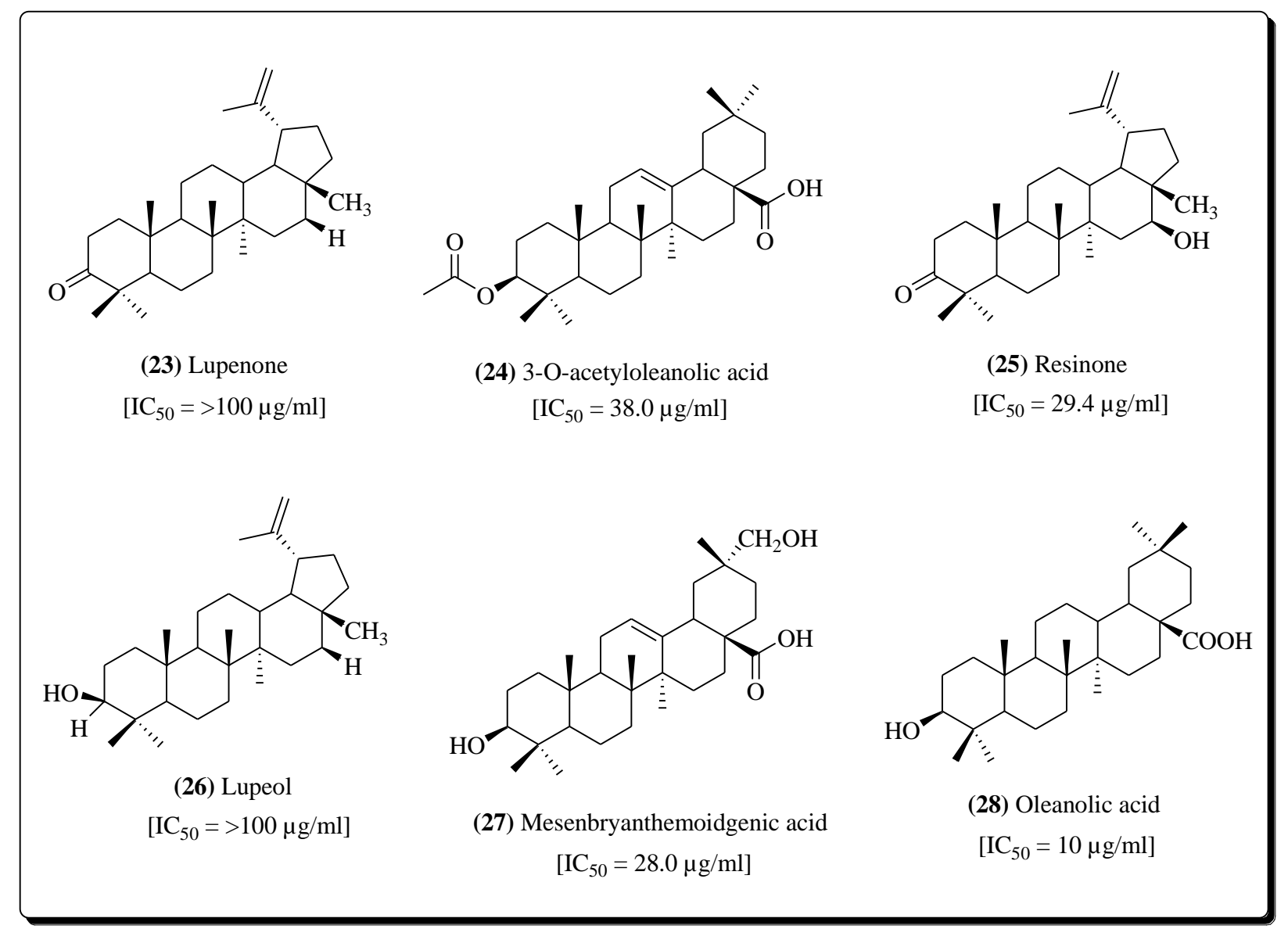

Figure 6. Compounds having Protease inhibitory activity

\subsubsection{Natural plants as Immunomodulators}

Immunomodulators are the agents that stimulate the cellular and humoral immune system against any pathogenic infection [148-150]. The dendritic cells of the immune system act as antigen representing cells and move alongwith antigen into the lymph nodes from the tissues. They represent the antigen to the $\mathrm{T}$ cells and the $\mathrm{T}$ cells then initiate immune response. $\mathrm{T}$ cells stimulate the $\mathrm{B}$ cells for the production of antibodies that bind with the antigen and the $\mathrm{T}$ cells activate killer $\mathrm{T}$ 
cells also which attack on the pathogen [151]. There are several classes of natural compounds that exhibit immunomodulatory properties such as; alkaloids, tannins, terpenoids, coumarins, glycosides, flavonoids, polysaccharides and lignans etc [152,153]. Among alkaloids, berberine (29) [148] is obtained from Hydrasti Canadensis [154], sinomenine (30) [148] is isolated from Sinomenium acutum [155], piperine (31) [148] is obtained from Piper longum [156], and tetrandrine is obtained from Stephania tetrandra [157] have shown immunomodulatory property in HIV infection. Among glycosides, aucubin is obtained from Plantago major [158], isorhamnetin-3-O-glucoside is extracted from Urtica dioica [159], and mangiferin is obtained from Mangifera indica [160] have exhibited immune stimulatory properties in HIV. Among phenols, ellagic acid (32) from Punica granatum [161], curcumin from Curcuma longa [162] and ferulic acid (33), vanilic acid (34) shown in Figure 7 [148] and chlorogenic acid are obtained from Plantago major [158], have been expressed effective immunomodulatory potential in AIDS. Within tannins, chebulagic acid and corilagin from Terminalia chebula [163] and punicalagin [164] act as immunomodulatory agents. Among flavonoids, centaurein from Bidens pilosa [165] and apigenin 7-O- $\beta$-D-neohesperidoside, orientin, vitexin and apigenin 7-O- $\beta$-D-galactoside obtained from Jatropha curcas [166], have exhibited the effective immunomodulatory action against HIV. From saponins, asiaticoside obtained from Centella asiatica [167] and glycyrrhizin is extracted from the roots of Glycyrrhiza glabra [168], have shown significant immunomodulatory activity.<smiles>COc1ccc2cc3c(cc2c1OC)-[n+]1c(cc2cc1OCO2)C3</smiles>

(29) Berberine<smiles>COC1=C[C@H]2CC[C@]3(CC(=O)C(OC)=CC3C2)c2c(ccc(OC)c2O)C1</smiles>

(30) Sinomenine<smiles>O=C(/C=C/C=C/c1ccc2c(c1)OCO2)N1CCCCC1</smiles>

(31) Piperine<smiles>O=c1oc2c(O)c(O)cc3c(=O)oc4c(O)c(O)cc1c4c23</smiles>

(32) Ellagic acid<smiles>COc1cc(/C=C/C(=O)O)ccc1O</smiles>

(33) Ferulic acid<smiles>COc1cc(C(=O)O)ccc1O</smiles>

(34) Vanilic acid

Figure 7. Plants based Immunomodulators

\subsubsection{Natural plants as Antioxidants}


In AIDS, many reactive oxygen species have been produced due to the alteration in the levels of antioxidant enzymes [169]. This further leads to the damage of DNA and lipid peroxidation [170]. Reactive oxygen species can also stimulate a NF- $\kappa B$ factor which helps in the transcription of HIV virus and thus promote its replication [171]. Antioxidants are the agents that reduce the levels of reactive oxygen species and protect the cellular DNA. N-Acetylcysteine is an agent that acts as antioxidant and used in the treatment of HIV infection [172]. Various other antioxidants like Selenium, lipoic acid, vitamin C, $\beta$-carotene and vitamin E are used in the HIV infection [173,174]. Cyanidin-3-glucoside (35) is an antioxidant obtained from the blackberry, have been used in HIV infection and Peonidin (36) given in Figure 8 is another antioxidant obtained from blackberry which is used in this infection $[148,175]$.

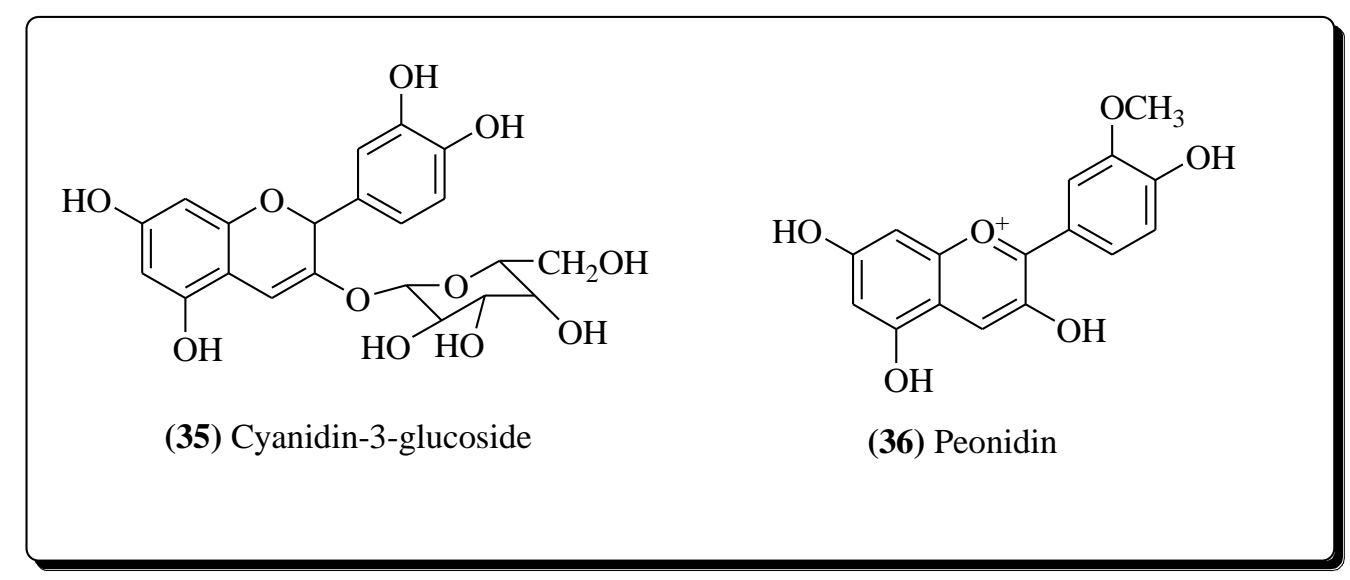

Figure 8. Plant based antioxidants used in AIDS.

\subsection{Plants according to their Secondary Metabolites}

Secondary metabolites are plant components that have some therapeutic activity. They are generally obtained from the primary metabolites such as carbohydrates, proteins, amino acids, phenolics etc [176-179]. Secondary metabolites mainly include alkaloids, glycosides, coumarins, terpenoids, lignans, tannins, pectins, flavonoids, phenols, lectins, proteins etc [180-182].

\subsubsection{Alkaloids}

Alkaloids are the basic nitrogen containing secondary metabolites of the plants, active against many diseases including HIV. Buchapine is a quinolone alkaloid obtained from Eodia roxburghiana, has shown an effective activity towards HIV infection [183]. From the roots of Tripterygium hypoglaucum, various alkaloid compounds have been extracted like hypoglaumine B and triptonine A (37) and B exhibiting anti-HIV activity and are used in the antiretroviral therapy [184]. Nitidine is another alkaloid that is isolated from plant roots of Toddalia asiatica, have shown a strong potential against HIV [185]. From the plant Symplocos setchuensis, an alkaloid harman (38) and another compound matairesinoside (39) is separated and is used in antiretroviral therapy for its anti-HIV potential. It acts on the viral replicativr enzymes and inhibits the HIV replication [186]. Another aromatic alkaloid polycitone A that is obtained from marine source Polycitor sp., exhibited potential activity against the reverse transcriptase of HIV. Hence, it efficiently prohibits the HIV replication. Several other marine sponges have been used which act against the viral diseases as well as the bacterial ones [187]. From Leitneria floridana, an alkaloid 1-methoxy canthionone is isolated for its anti-HIV property [188]. Papaverine is obtained from Papaver sominiferum, inhibits the HIV replication [33]. 
Norisoboldine and corydine are the two alkaloids obtained from the leaves of Croton echinocarpus, showing anti-HIV activity [189]. Table 2 depicts the plant based alkaloids possessing anti-HIV activity.

Table 2: Alkaloidal based compounds as Anti-HIV agents

\begin{tabular}{|c|c|c|c|}
\hline Plant Species & $\begin{array}{l}\text { Parts } \\
\text { used }\end{array}$ & Chemical Constituents & $\begin{array}{l}\text { Referenc } \\
\text { es }\end{array}$ \\
\hline $\begin{array}{l}\text { Ancistrocladus } \\
\text { korupensis }\end{array}$ & Leaves & Michellamine A, B and C & {$[190]$} \\
\hline $\begin{array}{l}\text { Stephania } \\
\text { cepharantha }\end{array}$ & Roots & Cepharantine & {$[191]$} \\
\hline Murraya siamensis & $\begin{array}{l}\text { Roots, } \\
\text { leaves }\end{array}$ & Siamenol & [192] \\
\hline Clausena excavate & Leaves & $\begin{array}{l}\text { O-Methylmukonal, clauszoline and } \\
\text { 3formyl-2,7-dimethoxy-carbazole }\end{array}$ & [193] \\
\hline Drymaria diandra & Leaves & Canthin4-one drymaritin & [194] \\
\hline Glycosmis Montana & $\begin{array}{l}\text { Twigs, } \\
\text { leaves }\end{array}$ & $\begin{array}{l}\text { (E)-3-(3-hydroxymethyl-2-butenyl)-7-(3-methyl-2-buten } \\
\text { yl)-1H-indole }\end{array}$ & [195] \\
\hline Aniba species & Stems & Anibamine & [196] \\
\hline $\begin{array}{l}\text { Zanthoxylum } \\
\text { ailanthoides }\end{array}$ & $\begin{array}{l}\text { Root } \\
\text { bark }\end{array}$ & Decarine, $\Upsilon$-fagarine and tembamide & [197] \\
\hline Nelumbo nucifera & Leaves & Coclaurine, norcoclaurine, reticuline & [198] \\
\hline Pericampylus glaucus & Leaves & Norruffscine, 8-oxotetrahydro-palmatine & [199] \\
\hline Begonia nantoensis & $\begin{array}{l}\text { Rhizom } \\
\text { es }\end{array}$ & Indole-3-carboxylic acid & {$[200]$} \\
\hline Leucojum vernum & Bulbs & Lycorine, homolycorine & {$[201]$} \\
\hline Epinetrum villosum & Root & Cycleanine & [202] \\
\hline Argemone mexicana & $\begin{array}{l}\text { bark } \\
\text { Roots }\end{array}$ & $\begin{array}{l}\text { 6-Acetonyldihydrochelerythrine, nuciferine } \\
\text { Crambescidin 826, fromiamycalin and crambescidin } 800\end{array}$ & [203] \\
\hline Monanchora sp. & Stems & $\begin{array}{l}\text { Manadomanzamines A and B } \\
\text { Hernandonine, lindechunine,7-oxohernangerine and }\end{array}$ & [204] \\
\hline $\begin{array}{l}\text { Acanthostrongylopho } \\
\text { rasp. }\end{array}$ & - & laurolistine & $\begin{array}{l}{[205]} \\
{[206]}\end{array}$ \\
\hline Lindera chunii & Roots & & [207] \\
\hline Artemisia caruifolia & Stems & & \\
\hline
\end{tabular}

Several alkaloid compounds such as, michellamine A (40) [190], siamenol (41) [192], decarine (42) [197], reticuline (43), norcoclaurine (44) [198], indole-3-carboxylic acid (45) [200], lycorine (46) [201], homolycorine (47) [201], cycleanine (48), 6-Acetonyldihydrochelerythrine (49) [203] and hernandonine (50) [206] have shown significant HIV inhibitory potential in Figure 9. 


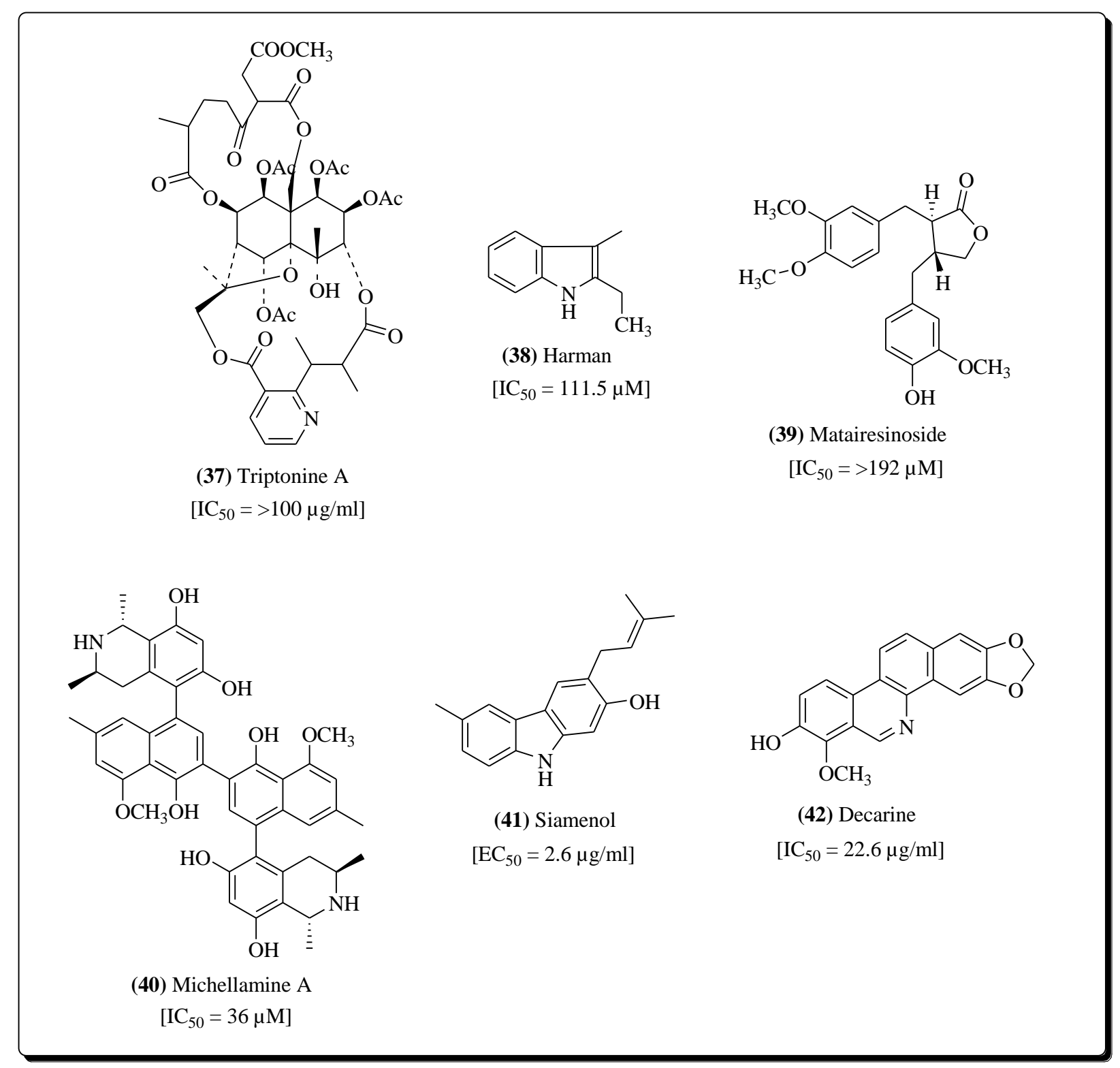

Figure 9. Alkaloidal compounds possessing anti-HIV activity. (Continue) 
<smiles>COc1ccc(CC2c3cc(O)c(OC)cc3CCN2C)cc1O</smiles>

(43) Reticuline<smiles></smiles>

(46) Lycorine<smiles>Oc1ccc(CC2NCCc3cc(O)c(O)cc32)cc1</smiles>

(44) Norcoclaurine<smiles>O=C(O)c1c[nH]c2ccccc12</smiles>

(45) Indole-3-carboxylic acid $\left[\mathrm{IC}_{50}=16.40 \mu \mathrm{g} / \mathrm{ml}\right]$<smiles>COc1ccc2c(c1OC)C(CC(C)=O)N(C)c1c-2ccc2cc3c(cc12)OCO3</smiles>

(49) 6-acetonyldihydrochelerythrine $\left[\mathrm{EC}_{50}=1.77 \mu \mathrm{g} / \mathrm{ml}\right]$<smiles>COc1cc2c(cc1OC)C1C(CC=C3CCN(C)[C@@H]31)OC2=O</smiles>

(47) Homolycorine<smiles>COc1cc2c3c(c1OC)Oc1ccc(cc1)C[C@@H]1CCN(C)c4cc(OC)c(OC)c(c41)Oc1ccc(cc1)C[C@@H]2N(C)CC3</smiles>

(48) Cycleanine $\left[\mathrm{EC}_{50}=1.83 \mu \mathrm{g} / \mathrm{ml}\right]$

Figure 9. Alkaloidal compounds possessing anti-HIV activity.

\subsubsection{Terpenoids}

Terpenoids are the secondary metabolites that are derived from the isoprene unit $\left(\mathrm{C}_{5} \mathrm{H}_{8}\right)$ [208]. Many plant terpenoids have been used for their therapeutic potential [209]. Plant terpenoids betulinic acid, oleanolic acid and platanic acid are isolated from Syzigium claviflorum leaves and have exhibited efficient inhibition of HIV replication [210]. Celasdin B (51) is a triterpene that is isolated from Celastrus hindsii belonging to the family Celastraceae, has reported to inhibit the HIV replication [211]. Prostratin has been expressed significant anti-HIV activities and is separated from Homalanthus nutans belonging to the family Euphorbiaceae [212]. From the stem bark of plant Garcinia speciosa, some anti-HIV therapeutic components have been isolated that are garcisaterpenes A, C and theprotostanes. They inhibit the activity of HIV reverse transcriptase and thus stop the HIV life cycle [213]. Maslinic acid (52) is a terpenoid compound that acts against the HIV protease enzyme and is obtained from Geum japonicum [214]. From the stems and roots of plant Kadsura 
lancilimba, another triterpene lancilactone $C(53)$ has been derived that restricts the viral replication [215]. Oleanolic acid is chief terpenoid isolated from many plant species including Xanthoceras sorbifolia belonging to the family Sapindaceae. It effectively inhibits the HIV replication and plays an important role in the treatment of AIDS [216]. Suberosol (54) is a lanostane type triterpenoid and is extracted from the leaves of Polyalthia suberosa, belonging to family Annonaceae has shown effective inhibition of HIV replication [217]. An another phorbol diester known as 12-O-tetradecanoylphorbol-13-acetate, has been exhibited anti-HIV activity and was obtained from Croton tiglium belonging to family Euphorbiaceae [212]. A Brazilian alga isolated from Dictyota pfaffii, from which an active diterpene component 8,10,18-trihydroxy-2,6-dolabelladiene has been extracted and has shown inhibitory activity of HIV reverse transcriptase [218,219]. A butenolide triterpene known as 3-epi-litsenolide $\mathrm{D}_{2}$ has been expressed significant anti-HIV activity and was extracted from Litsea verticilla [220]. Alga Dictyota menstrualis is an important source for various diterpenes that exhibit HIV reverse transcriptase inhibition potential [221]. From the roots and rhizomes of plant Clausena excavate, a limonoid terpene named as clausenolide-1-ethyl ether has been obtained and has used in the antiretroviral therapy [222]. Glycyrrhizin is another saponin terpenoid that consists of significant anti-HIV activity and prohibits the viral life cycle, has extracted from the Glycyrrhiza glabra roots [223]. Oleanolic acid is a potent anti-HIV component and is widely distributed in various plants involving leaves of Rosa woodsii, leaves of Syzygium claviflorum, aerial parts of Ternstromia gymnanthera, plant of Hyptis capitata and plant of Phoradendron juniperinum [216]. 12-Deoxyphorbol-13-phenylacetate is a phorbol ester and is obtained from the plant Euphorbia poissonii, has been reported for possessing anti-tumor activity and recently, it has been used in the antiretroviral therapy for its anti-HIV activity [224]. Pedilstatin [13-O-acetyl-12-O-(2'Z,4'Eoctadienoyl)-4 $\alpha$-deoxyphorbol] is another phorbol ester obtained from Pedilanthus sp., possessing anticancer and anti-HIV properties [225]. Some other plant species containing terpenoid compounds with efficient anti-HIV activity have been represented in the Table 3.

Table 3. Terpenoids act as Anti-HIV agents

\begin{tabular}{llll|} 
Plant Species & Parts used & Chemical Constituents & References \\
Propolis & Roots & Agallochin J, ribenone, angustanoic acid B & {$[226-228]$} \\
Homalanthus nutans & Roots & Melliferone, moronic acid, betulonic acid & {$[38,229]$} \\
Cassine xylocarpa & Stem & Prostratin & {$[230,231]$} \\
Glycyrrhiza uralensis & Roots & Galacturonic acid, xylose, uralsaponin C & {$[232]$} \\
Daphne gnidium & Aerial & Daphnetoxin, gniditrin, gnidicin & {$[233]$} \\
& parts & & {$[234]$} \\
Euphorbia micractina & Roots & Lanthyrane diterpenoids & \\
Kaempferia pulchra & Rhizomes & Kaempulchraol A, C, E & {$[235]$} \\
Picrasama javanica & Bark & Picrajavanicin A, javanicin B, picrasin A & {$[236]$} \\
Schisandra lancifolia & Leaves, & Lancifodilactone F & {$[237]$} \\
& stem & & {$[238]$} \\
Stellera chamaejasme & Roots & Stelleralide D, gnidimacrin & {$[239]$} \\
Lindera strychnifolia & Roots & Lindenanolides E, G and F & {$[240]$} \\
Daphne acutiloba & Roots & Wikstroelide M & {$[241]$} \\
\hline
\end{tabular}




\begin{tabular}{|c|c|c|c|}
\hline Annona squamosa & Leaves & 16 $\beta, 17$-dihydroxy-entkauran-19-oic acid & [242] \\
\hline Cimicifuga racemosa & Rhizomes & Actein & [243] \\
\hline Schisandra sphaerandra & Leaves & Nigranoic acid & [244] \\
\hline Allanthus altissima & Roots & Shinjulactone B & [245] \\
\hline Panax ginseng & Roots & Isodehydroprotopanaxatriol & [246] \\
\hline Garcinia hanburyi & $\begin{array}{l}\text { Stem, } \\
\text { roots }\end{array}$ & $\begin{array}{l}\text { 3-acetoxyalphitolic acid, 2-acetoxyalphitolic } \\
\text { acid }\end{array}$ & [247] \\
\hline \multirow[t]{2}{*}{ Euphorbia officinarum } & & 8-methoxyingol-7,12-diacetate-3-phenylacetate & [248] \\
\hline & Leaves & Dihydrocucurbitacin F & \\
\hline Hemsleya jinfushanensis & & Forskolin, 1-deoxyforskolin & [249] \\
\hline Coleus forskohlii & Tubers & 28-hydroxy-3-oxo-lup-20(29)-en-3-O-al & [250] \\
\hline Microtropis fokienensis & Roots & Betulonic acid & [251] \\
\hline Betula platyphylla & Stem & 25-hydroxy-3-oxoolean-12-en-28-oic acid & [252] \\
\hline \multirow[t]{2}{*}{ Amoora rohituka } & Roots & Capilliposide B & [253] \\
\hline & Stem bark & Ganoderic acid D & \\
\hline Lysimachia capillipes & & Ganoderiol F & {$[254]$} \\
\hline Ganoderma lucidum & Roots & Impatienside $\mathrm{A}$, bivittoside $\mathrm{D}$ & [255] \\
\hline Ganoderma amboinense & Stem, & 25-methoxyhispidol A & [256] \\
\hline Holothuria impatiens & Leaves & 23,24-dihydrocucurbitacin B & [257] \\
\hline Poncirus trifoliate & Stem & Dichapetalin A & [258] \\
\hline Trichosanthes kirilowii & - & Acutissimatriterpene A, B , E & [259] \\
\hline Dichapetalum gelonioides & Fruits & Celastrol & [260] \\
\hline Phyllanthus acutissima & Roots & $3 \alpha, 7 \alpha$-dideacetylkhivorin & [261] \\
\hline Celastrus orbiculatus & Stem bark & Nimbolide & [262] \\
\hline Khaya senegalensis & Aerial & Gedunin, $1 \alpha$-hydroxy1,2-dihydrogedunin & [263] \\
\hline Azadirachta indica & parts & $6 \alpha$-tigloyloxychaparrinone & [264] \\
\hline \multirow[t]{2}{*}{ Xylocarpus granatum } & Bark & & [265] \\
\hline & Roots & & \\
\hline \multirow[t]{3}{*}{ Ailanthus integrifolia } & Flowers & & [266] \\
\hline & - & & \\
\hline & Roots & & \\
\hline
\end{tabular}

Many of the terpenoid compounds with their chemical structures have been represented in Figure 10, melliferone (55) [38], moronic acid (56) [38], ribenone (57) [226], germanicol (58) [232], nivadiol (59) [232], wikstroelide M (60) [241], shinjulactone B (61) [245], ganoderic acid D (62) [255], ganoderiol F (63) [256] gedunin (64) [265] and $1 \alpha$-hydroxy1,2-dihydrogedunin (65) [265] exhibiting anti-HIV activity. 


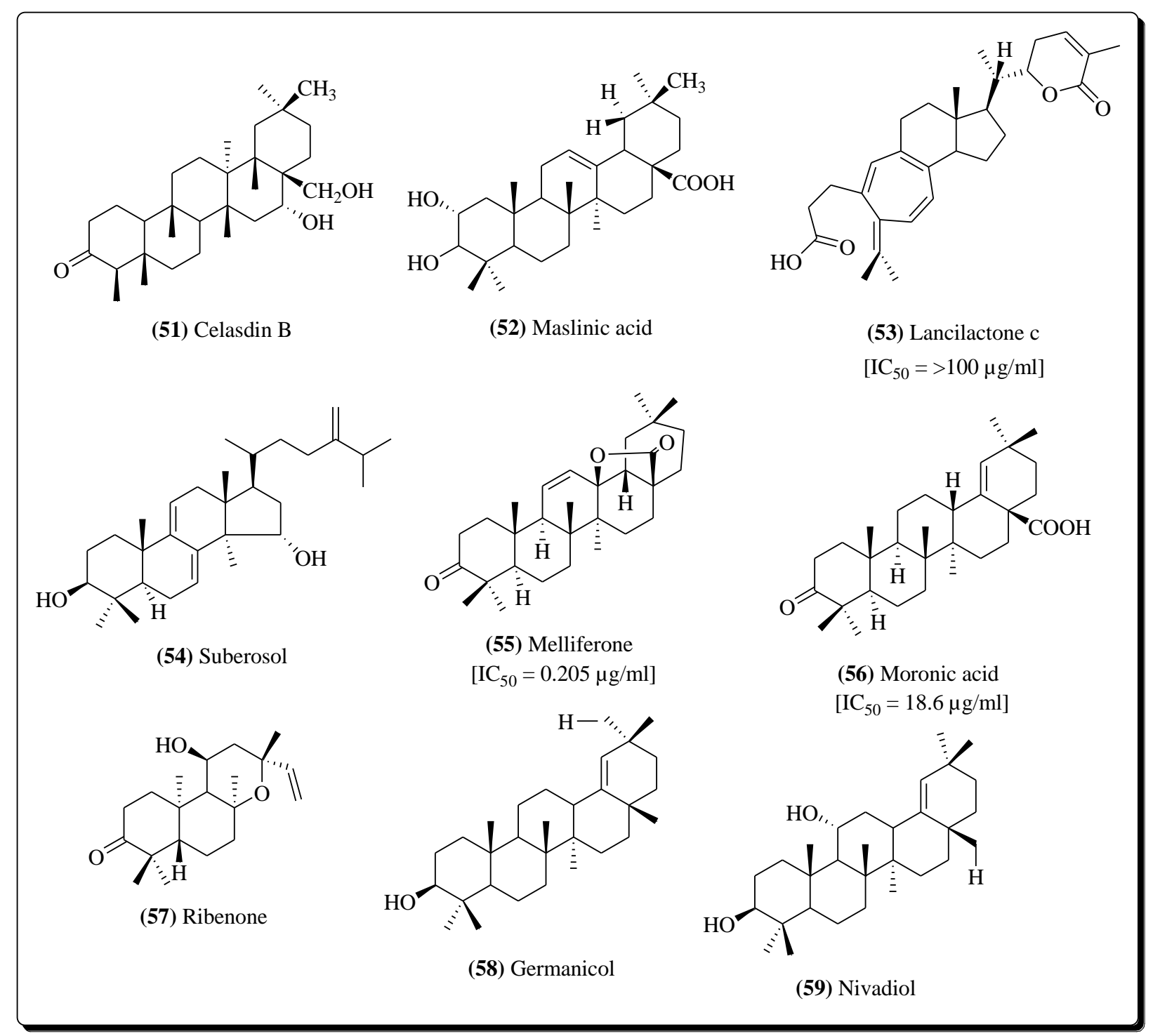

Figure 10. Potent Terpenoids in HIV. (Continue) 
<smiles>C=C(C)[C@]1(O)C[C@@H](C)C2[C@@H]([C@@H](C=O)C(CO)C(O)[C@@]3(O)C(=O)C(C)=C[C@H]23)[C@H]1OC(=O)/C=C/C=C/CCCCC</smiles>

(60) Wikstroelide M<smiles>C[C@H](CC(=O)C[C@@H](C)[C@H]1CC(=O)[C@H]2C3=C(C(=O)C[C@@]21C)[C@@]1(C)CCC(=O)[C@H](C)[C@H]1C[C@H]3O)C(=O)O</smiles>

(62) Ganoderic acid D<smiles>CC(=O)OC1CC2C(C)(C)C(=O)C=C[C@]2(C)C2CC[C@H]3C(c4ccoc4)OC(=O)C4OC43C12C</smiles>

(64) Gedunin $\left[\mathrm{IC}_{50}=16.83 \mu \mathrm{M}\right]$

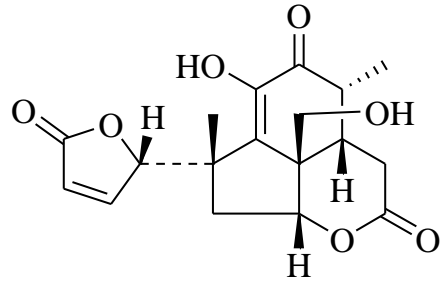

(61) Shinjulactone B $\left[\mathrm{IC}_{50}=>287 \mu \mathrm{M}\right.$ ]<smiles>CCC(=CCC[C@@H](C)[C@H]1CC[C@H]2C3=CC[C@H]4[C@@H](C)C(=O)CC[C@]4(C)C3=CC[C@]21C)CC</smiles>

(63) Ganoderiol F

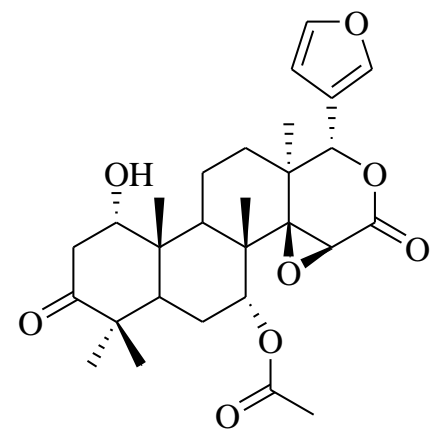

(65) 1 a -hydroxy1,2-dihydrogedunin

Figure 10. Potent Terpenoids in HIV.

\subsubsection{Flavonoids}

Flavonoids are the plant components and have shown several antiviral and antioxidant properties. Thus these are used in various viral diseases [267]. Flavonoids like quercetin 3-O-(2-galloyl) a $L$-arbinopyranose and gallate ester have been separated from Acer okamotoanum belonging to family Aceraceae, exhibited significant activity against integrase of HIV [268]. Xanthohumol (66) is an important flavonoid that is isolated from Humulus lupulus, has shown anti-HIV activity [269]. Two flavonoids 6,8-diprenylkaempferol and 6,8-diprenylaromadendrin have expressed a potential activity against the AIDS virus and were isolated from plant Monotes africanus [270]. From Wikstroemia indica plant roots belonging to the Thymelaeaceae, a biflavonoid named wikstrol B (67) has been extracted and is used for its anti-HIV activity [271]. Baicalin is a flavonoid compound that prohibits HIV replication and is derived from the plant Scutellaria baicalensis [272]. From twigs and 
leaves of medicinal plant Rhus succedanea, various anti-HIV flavonoids have been separated that act on the polymerase of the reverse transcriptase of HIV-1. The flavonoids robustaflavone, biflavonoids and hinokiflavone are the potent inhibitors of HIV replication [273]. 2-methoxy-3-methyl-4,6-dihydroxy-5-(3'-hydroxy)-cinnamoylbenzaldehyde is a chalcone flavonoid that has been extracted from Desmos spp. roots and exhibited strong activity against HIV-1 [274]. Hydroxypanduratin A is a chalcone that acts on the HIV protease enzyme and is obtained from the rhizomes of Boesenbergia pandurata [275].

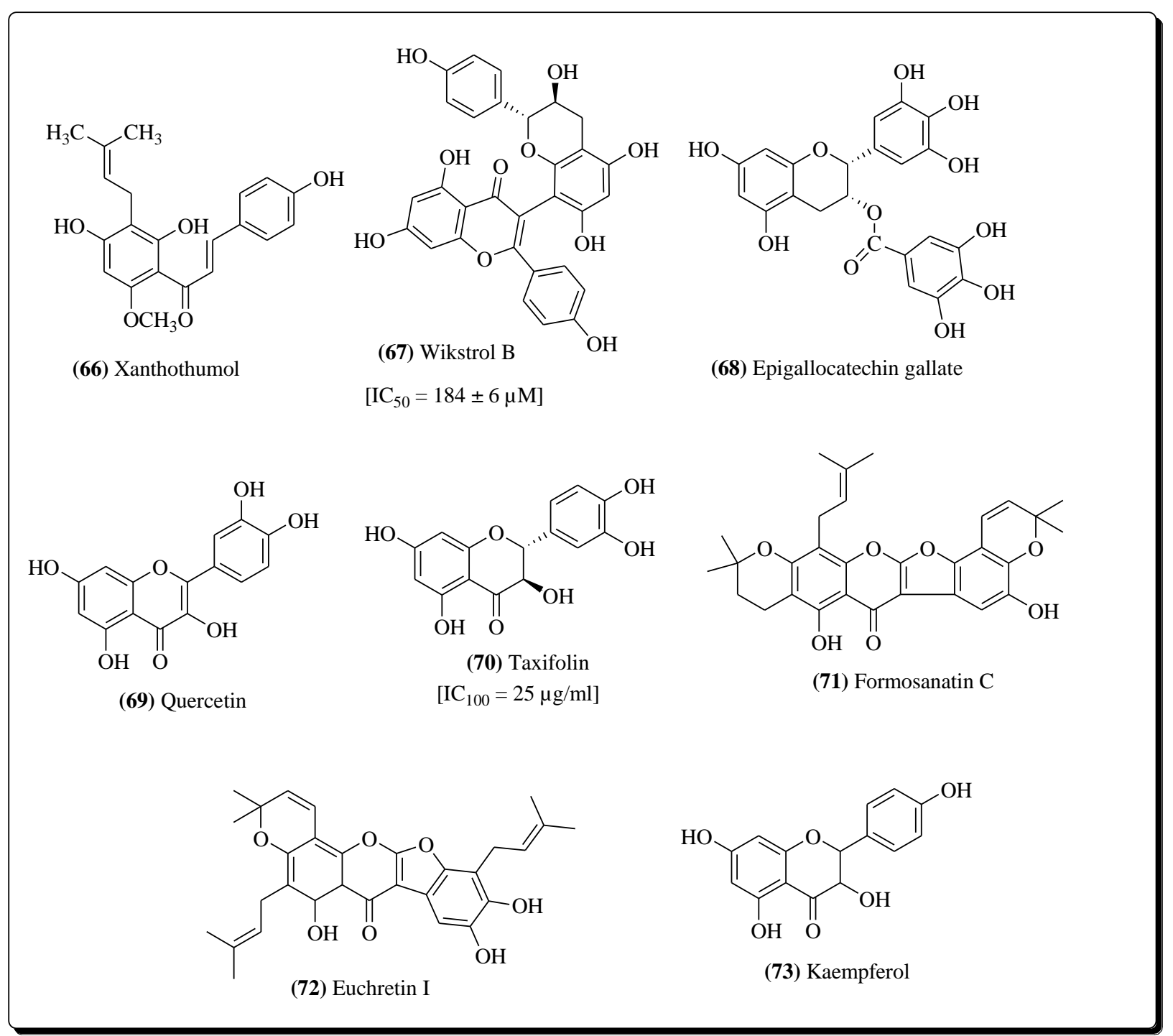

Figure 11. Flavanoid based copounds used as Anti-HIV agents.

Several flavonoids like chrysin, epigallocatechin gallate (68) and quercetin (69) have been islotaed from a number of plants and are reported to show potent inhibitory activity on the replication of HIV virus [276,277]. Thalassiolins A, B and C are flavonoid compounds that act on the HIV integrase and prohibit the life cycle of HIV-1 and are obtained from the grass Thalassia testudinum. Thalassiolin A is the most potent compound which prohibits the terminal cleavage [278]. Some biflavonoids such as 2",3"-dihydroochnaflavone 7"-O-methylether and ochnaflavone 7"-O-methyl ether are isolated from Ochna integerrima, have shown moderate to weak anti-HIV activity [280]. Another flavonoid taxifolin (70) which is also known as dihydroquercetin is chiefly 
extracted from the stems of Juglans mandshurica, expressed strong inhibitory activity on the reverse transcriptase enzyme of HIV and thus plays a role in the prevention of HIV replication [281]. From Chrysanthemum morifolium flowers, two important flavonoids apigenin 7-O $\beta$ -D-(4'caffeoyl)glucuronide and glucuronide have been extracted that exhibited a significant activity on the integrase of HIV-1 [282]. Mentha longifolia is another plant whose methanolic extracts are used for the isolation of several therapeutic flavonoids and are considered to act on the HIV reverse transcriptase [283]. Several other flavonoids such as flemiphyllin, formosanatin C (71), euchretin I (72) and quercetin are reported to inhibit the HIV replication and are obtained from the alcoholic extracts of Euchresta formosana [284]. Many important flavonoids such as epicatechin-3-O-gallate and epicatechin have extracted from Detarium microcarpum, shown anti-HIV potential [285]. 4'-methylepigallocatechin-3'-O $\beta$-glucopyranoside, and 4'-methylepigallocatechin-5-O- $\beta$-glucopyranoside are two medicinal flavonoids that are separated from Maytenus senegalensis and exhibit anti-HIV activity [286]. Kaempferol (73) presented in Figure 11, a tetrahydroxyflavonol shown inhibitory activity on the protease enzyme and is isolated from Rosa damascene [287, 288].

\subsubsection{Coumarins}

Calanolides are a group of coumarins that act as non-nucleoside reverse transcriptase inhibitors and are derived from the genus Calophyllum belonging to family Clusiaceae [289]. Calanolide A [290] and Calanolide B along with its derivative known as 7,8-dihydrocalanolide B are obtained from the plant Calophyllum lanigerum, have shown inhibition of the cytopathogenic results of HIV on the cells of host [289]. Another coumarin named suksdorfin (74) [292] is isolated from the fruits of Lomatium suksdorfii belonging to the family Apiaceae, which has expressed inhibitory property on the HIV replication [291]. Cordatolide A and B are the coumarin compounds obtained from Calophyllum cordato-oblongum, inhibit the replication of the HIV virus and are very identical in structures with the Calanolides [289]. Other coumarins like heraclenol (75), heraclenin (76) and imperatorin (77) also inhibit HIV replication and are extracted from Ferula sumbul roots [293]. Several furanocoumarins such as bergapten (78) and psolaren are extracted from the roots of Prangos tschimganica, have exhibited significant activity against the HIV virus [294]. Mesuol (79) is another coumarin compound from the category 4-phenylcoumarin, also reported inhibiting the replication of HIV-1. It prohibits the reverse transcription and phosphorylation of HIV [295]. A semisynthetic derivative of calanolide known as oxocalanolide acts efficiently against HIV [296]. Various furanocoumarins like imperatorin, xanthotoxin and xanthotoxol have been extracted from the Aegle marmelos fruits $[110,111]$. The stem, roots, fruits, leaves, seeds and bark of the A. marmelous are used for their significant therapeutic properties and have an important role in the Ayurvedic medication. The component imperatorin is reported to exhibit about $60 \%$ inhibition of HIV-RT. Other furanocoumarins xanthotoxin (80) and xanthotoxol (81) do not have a prenyl group, thus they exhibit weak activity shown in Figure 12 [297,298]. 


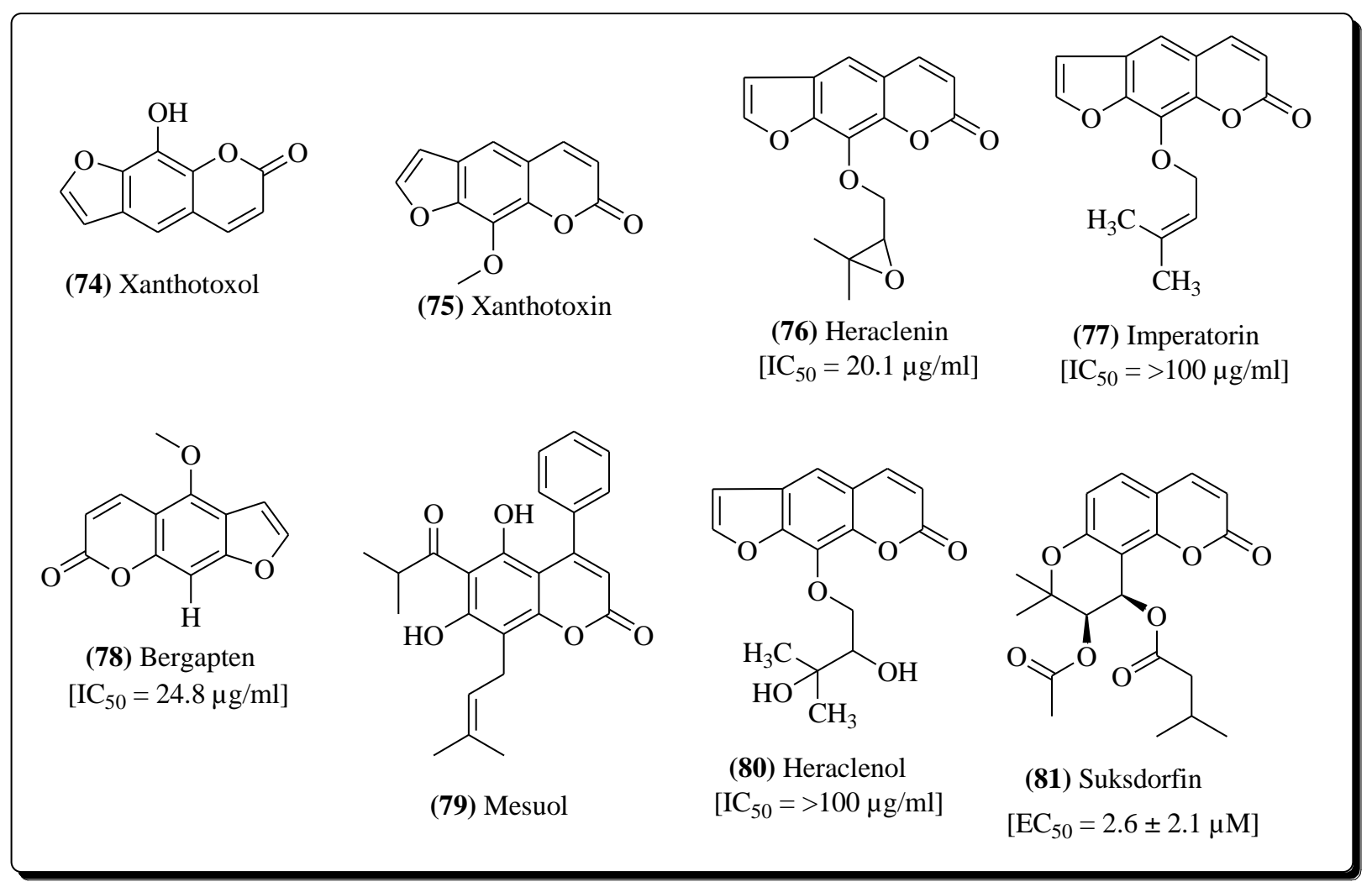

Figure 12. Coumarins based molecule with significant Anti-HIV potential.

\subsubsection{Proteins}

Proteins are the amino acid-containing plant components that usually contain ribosome-inactivating proteins as well as lectins [299]. A plant protein called MAP30 possessed anticancer potential along with anti-HIV properties and is obtained from Momordica charantia [300]. Trichosanthin is a ribosome-inactivating protein that exhibit anti-HIV activity and is isolated from Trichosanthes kirilowii [301]. Various plant ribosome-inactivating proteins have been identified for their anti-HIV activity. Momordica balsamina is a plant from which an anti-HIV ribosome-inactivating protein balsamin has been extracted [302]. Pf-gp6 is another protein that is extracted from Perilla frutescens has exhibited an inhibitory action on the HIV replication [303]. Some ribosome-inactivating proteins known as Pokeweed antiviral proteins have been separated from a pokeweed plant called Phytolacca americana, expressed efficient anti-HIV activity [304]. Some plant proteins along with their botanical sources have been given in Table 4.

Table 4: Proteins containing plants used in HIV

\begin{tabular}{|llll|}
\hline Plant Species & Parts used & Proteins & References \\
\hline Allium ascalonicum & Bulbs & Ascalin & {$[305]$} \\
Chrysanthemum coronarium & Seeds & Chrysancorin & {$[306]$} \\
Ginkgo biloba & Seeds & Ginkbilobin & {$[307]$} \\
Arachis hypogaea & Seeds & Hypogin & {$[308]$} \\
Lyophyllum shimeji & Fruit bodies & Lyophyllin & {$[309]$} \\
Panax quinquefolium & Roots & Quinqueginsin & {$[310]$} \\
\hline
\end{tabular}




\begin{tabular}{|c|c|c|c|}
\hline Flammulina velutipes & Fruit bodies & Velutin & [311] \\
\hline Tricholoma giganteum & Fruit bodies & Laccase protein & [312] \\
\hline Castanea mollisima & Seeds & Mollisin & [313] \\
\hline Treculia obovoidea & Bark & Treculavirin & [314] \\
\hline Vigna sesquipedalis & Seeds & Ground bean lectin & [315] \\
\hline Delandia unbellata & Seeds & Delandin & [316] \\
\hline Dorstenia contrajerva & Leaves & Contrajervin & [314] \\
\hline Vigna angularis & Seeds & Angularin & [317] \\
\hline Castanopsis chinensis & Seeds & $\begin{array}{l}\text { Castanopsis thaumatin } \\
\text { protein }\end{array}$ & [318] \\
\hline Vigna unguiculata & Seeds & Cowpea $\alpha$ protein & [319] \\
\hline Phaseolus vulgaris & Seeds & A homodimeric lectin & {$[320]$} \\
\hline Actinidia chinensis & Fruits & Kiwi fruit thaumatin & [321] \\
\hline Lentinus edodes & Fruit bodies & protein & [322] \\
\hline Allium tuberosum & Shoots & Lentin & [323] \\
\hline Phaseolus vulgaris & Seeds & A mannose-binding lectin & [324] \\
\hline Lilium brownie & Bulbs & Phasein A & [325] \\
\hline Vicia faba & Seeds & $\begin{array}{l}\text { Lilin } \\
\text { A trypsin-chymotrypsin }\end{array}$ & [326] \\
\hline Vigna unguiculata & Seeds & Inhibitor peptide & [327] \\
\hline Panax notoginseng & Roots & Unguilin & [328] \\
\hline Phaseolus vulgaris & Seeds & A xylanase & [329] \\
\hline Cicer arietinum & Seeds & $\begin{array}{l}\text { Vulgin } \\
\text { Chickpea cyclophilin-like }\end{array}$ & [330] \\
\hline Basella rubra & Seeds & protein & [331] \\
\hline Delandia unbellata & Seeds & $\begin{array}{l}\alpha \text {-Basrubrin } \\
\text { Rice bean peptide }\end{array}$ & [332] \\
\hline
\end{tabular}

\subsubsection{Tannins}

Tannins are mainly categorized into hydrolyzable and non-hydrolyzable, also called condensed tannins [333]. The hydrolyzable tannins include gallic acid polyesters (gallotannins) and hexahydroxydiphenic acids that is ellagitannins. The non-hydrolyzable or condensed tannins consist of flavan-3-ol moieties which are generally known as proanthocyanidins [334]. Corilagin (82) and geraniin (83) represented in Figure 13 are the two ellagitannins that possessed anti-HIV activity and have extracted from Phyllanthus amarus roots [335]. From the plant Cupressus sempervirens, a proanthocyanidin compound is obtained containing anti-HIV property [336]. Catechins are the polyphenols that are obtained from the green tea and theaflavins (84) are obtained from black tea, possessing antiviral activity. Theaflavins and their derivatives are the potent inhibitors of HIV replication [337]. 


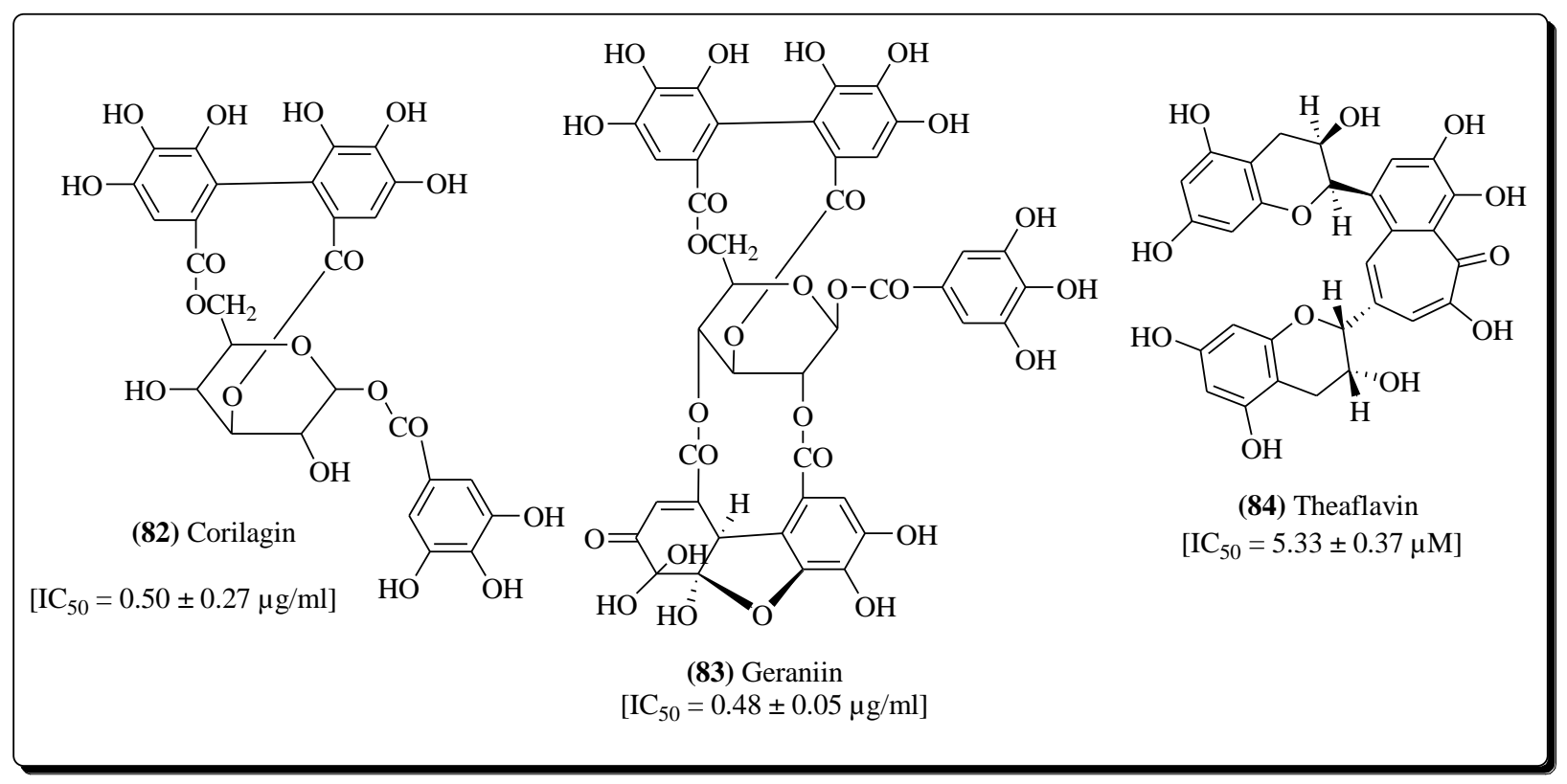

Figure 13. Tannins containing compounds used in HIV.

\subsubsection{Lignans}

Lignans are the secondary metabolites of the plants and many of them have shown strong activities against viral diseases including AIDS [338]. Several lignans like anolignan A (85) and B along with dibenzylbutadiene lignans have been isolated from Anogeissus acuminate and have exhibited significant activity against HIV virus [339]. From the plant Phyllanthus myrtifolius belonging to the family Euphorbiaceae, phyllamyricin D (86) and phyllamyricin F shown in Figure 14 (87) are isolated and possess inhibitory activity against the HIV-RT enzyme [340]. Gomisin is another lignan isolated from Kadsura interior, shown potent inhibitory activity against reverse transcriptase enzyme of HIV [341]. From the plant Arnebia euchroma, some caffeic acid isomers have been evaluated and have expressed weak activity against the HIV replication [342]. 2-hydroxy-2 (3',4'-dihydroxyphenyl)- methyl-3- (3",4"-dimethoxyphenyl) methyl $\gamma$-butyrolactone is a dibenzylbutyrolactone type lignin that is extracted from Phenax angustifolius, has been expressed anti-HIV activity [343]. From Schisandra rubriflora fruits other dibenzocyclooctadiene type lignans have been isolated having anti-HIV activity known as rubrisandrin A and rubrisandrin B [344]. 


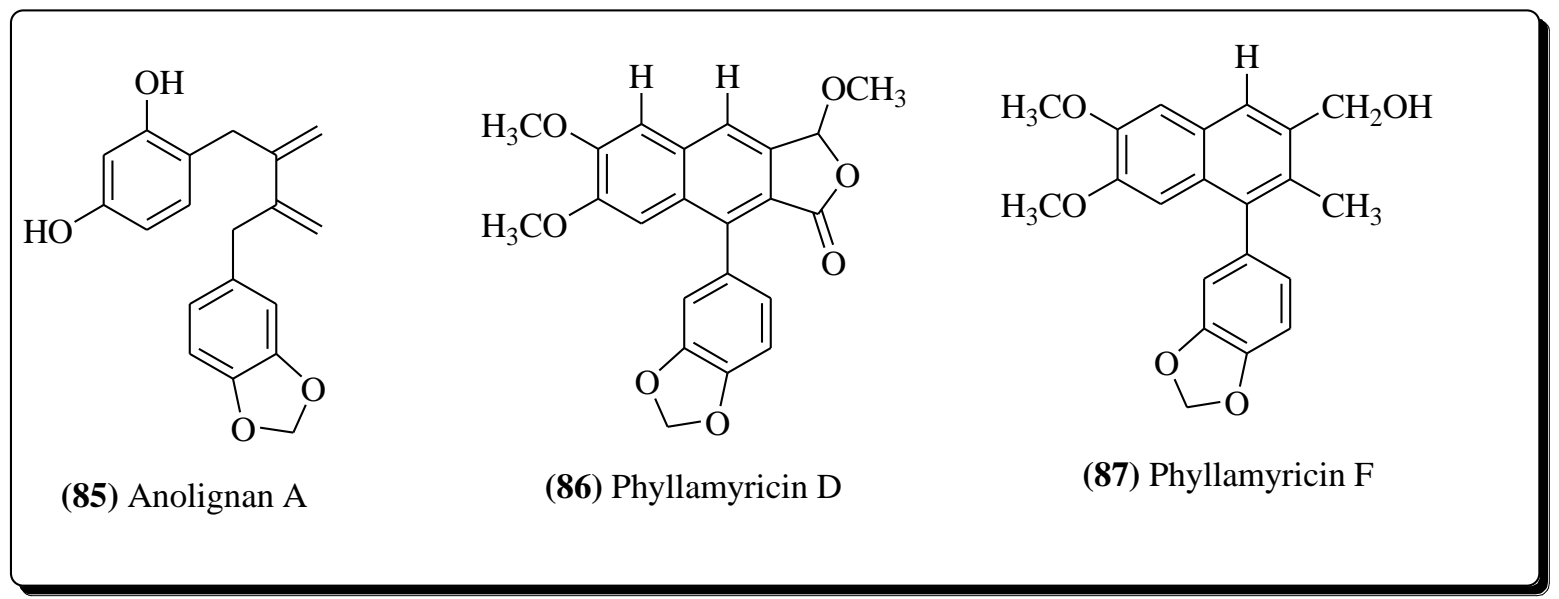

Figure 14. Lignans possessing anti HIV actions.

\subsubsection{Miscellaneous plants used as anti-HIV agents}

A number of plants have been evaluated for their anti-HIV activity and are being used in antiretroviral therapy for AIDS [1, 2]. Various phenolic compounds such as Quercus pedunculata, Terminalia horrida, Phyllanthus emblica and Rumex cyprius have been identified for their anti-HIV activity [345,346]. From the plant Strychnos vanprukii leaves and twigs, various betulinic acid derivatives have been extracted that exhibit strong potential anti-HIV activity. These are

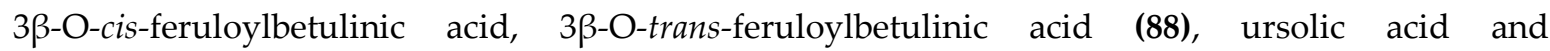
3ß-O-trans-coumaroylbetulinic acid (89) [347]. Various therapeutic components have been extracted from the bark of Cinnamomum zylanicum by suitable extraction [348]. The constituents have shown anti-inflammatory [349], anti-cancer, antiviral, antioxidant and immunomodulatory properties [350]. The ingenol compound extracted from the plant Euphorbia ingens has exhibited anti-HIV activity [351]. It also represents many anti-inflammatory and immunomodulatory potentials [352,353]. Oldenlandia affinis is a medicinal plant from which various cyclotides have been isolated for their anti-HIV activity [354,355]. Another plant Plectranthus barbatus have shown various antiviral, antibacterial and antifungal properties along with antioxidant and anti-inflammatory effects [356,357]. From the plant Clausena excavate some therapeutic constituents like O-methylmukonal (90), 3-formyl-2,7dimethoxycarbazole, limonoid, and clausenidin have been isolated for their anti-HIV property [358, 359]. Several antiviral components like tectorigenin, cytisine (91), formononetin, trifolirhizin (92), mattrine (93), blumenol A (94), pterocarpin (95), 30,40,5-trihydroxyisoflavone, euchretin and 5,7-dihydroxy-3-(2-hydroxy-4-methoxy-phenyl)-chromen-4-one have been isolated from Euchresta formosana and exhibited anti-HIV activity [360-363].

Extracts from the plant Alepidea amatymbica, have shown efficient anti-HIV activity and inhibit the HIV replication [364]. Artemisinin is obtained from the plant Artemisia annua, have exhibited antimalarial and anti-HIV activities [365]. Rosmarinic acid is a polyphenolic compound that is isolated from the plant Prunella vulgaris, is used for the anti-HIV potential [366]. From the plant Polygonum glabrum, various medicinal constituents with antiretroviral activity have been obtained such as (2)-2-methoxy-2-butenolide-3-cinnamate, pinocembrin

(96), 3-hydroxy-5methoxystilbene (97), sitosterol-3-O- $\beta$-Dglucopyranoside and pinocembrin-5-methyl 
ether [367]. Actein (98) is extracted from the rhizomes of plant Cimicifuga racemosa, has possessed significant activity against the HIV virus [368]. Chrysoeriol is separated from Eurya ciliate, has used for anti-HIV activity [369]. Several constituents have been isolated for anti-HIV potential from the stems of plant Aristolochia manshuriensis. Some of them are demethylaristofolin E (99), aristofolin, denitroaristolochic acid, aristolochic acid, aristomanoside (100), N-p-coumaroyltyramine, p-hydroxybenzoic acid etc. [370-374]. Malaferin A, is isolated from Malania oleifera for its antiviral property [375]. Diptoindonesin D, Acuminatol (101), Shoreaphenol, Hopeahainol and Vaticanol B have separated from the plant Vatica mangachapoi and are used in the antiretroviral therapy [376-379]. Cararosinol C and D, maackin and scirpusin B (102) are extracted from the plant Caragana rosea for their anti-HIV effects [380]. Structures of some important constituents obtained from plants effective in HIV therapy are represented in Figure 15. 


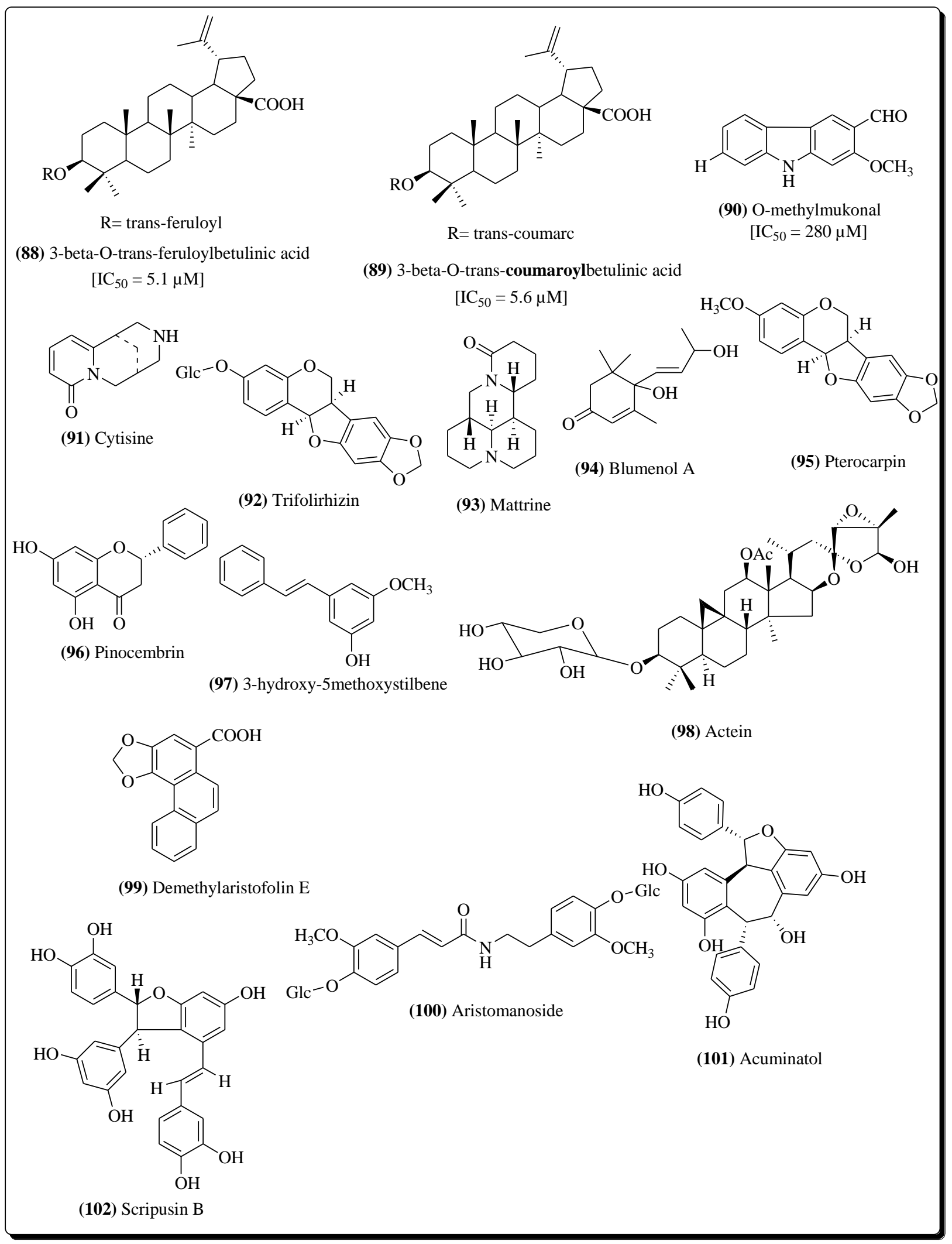

Figure 15. Plant-based compounds having anti-HIV activity.

Table 5. Assortments of other plant species have been given in the Table 5. 


\begin{tabular}{|c|c|c|c|}
\hline Plant Species & Family & Parts used & References \\
\hline Khaya grandifoliola & Meliaceae & Leaves & [381] \\
\hline Diospyros mespiliformis & Ebenaceae & Bark & [382] \\
\hline Alternanthera brasiliana & Amaranthaceae & Roots & [383] \\
\hline Ricinus communis & Euphorbiaceae & Leaves & {$[384]$} \\
\hline Butea monosperma & Fabaceae & Roots & [385] \\
\hline Prosopis glandulosa & Fabaceae & Leaves & [386] \\
\hline Sophora tonkinensis & Fabaceae & Roots & [387] \\
\hline Gunnera magellanica & Gunneraceae & Stem & [388] \\
\hline Swertia franchetiana & Gentianaceae & Roots & [389] \\
\hline Curcuma longa & Zingiberaceae & Rhizomes & [390] \\
\hline Stewartia koreana & Theaceae & Leaves & [391] \\
\hline Cissus quadrangularis & Vitaceae & Stems & [392] \\
\hline Withania somnifera & Solanaceae & Roots & [393] \\
\hline Ailanthus altissima & Simaroubaceae & Stem bark & [394] \\
\hline Toddalia asiatica & Rutaceae & Roots & [395] \\
\hline Oldenlandia herbacea & Rubiaceae & Roots & [396] \\
\hline Aloe vera & Xanthorrhoeaceae & Leaves & [397] \\
\hline Urtica dioica & Urticaceae & Rhizomes & [398] \\
\hline Rheum tanguticum & Polygonaceae & Leaves & [399] \\
\hline Saccharum officinarum & Poaceae & Stems & [400] \\
\hline Ochna integerrima & Ochnaceae & Leaves & [401] \\
\hline Nelumbo nucifera & Nelumbonaceae & Leaves & [402] \\
\hline Aglaia lawii & Meliaceae & Leaves & [403] \\
\hline Fritillaria cirrhosa & Liliaceae & Rhizomes & {$[404]$} \\
\hline Magnolia biondii & Magnoliaceae & Flower buds & [405] \\
\hline Lythrum salicaria & Lythraceae & Leaves & [406] \\
\hline Reseda lutea & Resedaceae & Whole plant & [407] \\
\hline Hypericum perforatum & Hypericaceae & Leaves & [408] \\
\hline Trigonostemon thyrsoideus & Euphorbiaceae & Stems & [409] \\
\hline Hemsleya endecaphylla & Cucurbitaceae & Tubers & [410] \\
\hline Garcinia kingaensis & Clusiaceae & Stem bark & [411] \\
\hline Woodwardia unigemmata & Blechnaceae & Rhizomes & [412] \\
\hline Berberis holstii & Berberidaceae & Roots, leaves & [413] \\
\hline Foeniculum vulgare & Apiaceae & Fruits & [394] \\
\hline Alepidea amatymbica & Apiaceae & Roots & [414] \\
\hline Stachytarpheta jamaicensis & Verbenaceae & Whole plant & [415] \\
\hline Schisandra sphaerandra & Schisandraceae & Stems & [416] \\
\hline Alpinia galangal & Zingiberaceae & Roots & [417] \\
\hline Zanthoxylum chalybeum & Rutaceae & Root bark & [418] \\
\hline Berchemia berchemiifolia & Rhamnaceae & Bark & [419] \\
\hline Scoparia dulcis & Plantaginaceae & Leaves & {$[420]$} \\
\hline Phyllanthus myrtifolius & Phyllanthaceae & Fruits & [421] \\
\hline
\end{tabular}


Arundina graminifolia

Ximenia Americana

\author{
Orchidaceae \\ Olacaceae
}

Whole plant

Stem bark

\section{Conclusions}

A significant number of reports on capable nascent natural and synthetic therapeutic compounds as anti- HIV agents discussed in the last few decades, this review article presents the rational approaches for the design of therapeutic potential candidates as anti- HIV agents. Even though there have been many extensive achievements in the fields of HIV chemotherapy, still there is a great demand for novel anti-HIV drug development and drug discovery. A number of plant species have been evaluated for their inhibitory activity on the essential HIV enzymes such as reverse transcriptase, protease and integrase which play an important role in the HIV replication. Several secondary metabolites have been extracted from the various plants that act as potent anti-HIV agents via different mechanisms of action. Therapeutically active compounds from natural plants can also aid as necessary leads for the discovery and development of novel and more potent compounds that can be derived synthetically. For instance, synthetic ingenol compounds have been derived on the basis of naturally occurring compound Ingenol and a variety of synthetic derivatives have been evolved from the naturally occurring compound Artemisinin, exhibiting a significant anti-HIV activity of potential scaffolds from them for the complete eradication of HIV/AIDS.

Author Contributions: Conceptualization, G.K.G, F.N.K and D.K.; methodology, R.K., P.S. and D.K.; software, data curation, R.K., P.S., F.N.K and D.K.; writing-original draft preparation, R.K., P.S., and D.K., writing - review and editing, R.K., P.S., G.K.G, F.N.K and D.K.; visualization, X.X.; supervision, F.N.K. and D.K.; project administration, F.N.K., G.K.G, and D.K..; funding acquisition, F.N.K. All authors have read and agreed to the published version of the manuscript.

Funding: FNK would also like to acknowledge the European Structural and Investment Funds, OP RDE-funded project 'ChemJets' (No. CZ.02.2.69/0.0/0.0/16_027/0008351).

Acknowledgments: Authors are thankful to Prof. B. S. Guman, Vice-chancellor of Punjabi University Patiala for their encouragements. Authors are also thankful to Er. S. K. Punj, Chairman, Sri Sai Group of Institutes and Smt. Tripta Punj, Managing Director, Sri Sai Group of Institutes for their constant moral support.

Conflicts of Interest: The authors declare no conflict of interest.

\section{References}

1. Sabde, S.; Bodiwala, H. S.; Karmase, A.; Deshpande, P. J.; Kaur, A.; Ahmed, N.; Chauthe, S. K.; Brahmbhatt, K. G.; Phadke, R. U.; Mitra, D.; Bhutani, K. K.; Singh, I. P. Anti-HIV activity of Indian medicinal plants. J. Nat. Med. 2011, 65, 662-669.

2. Salehi, B.; Kumar, N. V. A.; Sener, B.; Sharifi-Rad, M.; Kılıç, M.; Mahady, G. B.; Vlaisavljevic, S.; Iriti, M.; Kobarfard, F.; Setzer, W. N.; Ayatollahi, S. A.; Ata, A.; Sharifi-Rad, J. Medicinal plants used in the treatment of human immunodeficiency virus. Int. J. Mol. Sci. 2018, 19, 1459.

3. Reynolds, C.; Koning, C. B. de; Pelly, S. C.; Otterlo, W. A. L.; Bode, M. L. In search of a treatment for HIV current therapies and the role of non-nucleoside reverse transcriptase inhibitors (NNRTIs). Chem. Soc. Rev. 2012, 41, 4657-4670.

4. Prasad, S.; Tyagi, A. K. Curcumin and its analogues: A potential natural compound against HIV 1 infection and AIDS. Food Funct. 2015. 
5. Kharsany, A.B.; Karim, Q.A. HIV infection and AIDS in sub-saharan Africa: Current status, challenges and opportunities. Open AIDS J. 2016, 10, 34-48.

6. Moir, S.; Chun, T.-W.; Fauci, A.S. Pathogenic mechanisms of HIV disease. Annu. Rev. Pathol. Mech. Dis. 2011, 6, 223-248.

7. Deeks, S.G.; Overbaugh, J.; Phillips, A.; Buchbinder, S. HIV infection. Nat. Rev. Dis. Prim. 2015, 1, 15035.

8. Freed, E. O. HIV-1 assembly, release and maturation. Nature Reviews Microbiology 2015.

9. Engelman, A.; Cherepanov, P. The structural biology of HIV-1: mechanistic and therapeutic insights. Nature Reviews Microbiology 2012, 10, 279-290.

10. Turner, B. G.; Summers, M. F. Structural biology of HIV. J. Mol. Biol. 1999, 285, 1-32.

11. Goodsell, D. S. Illustrations of the HIV Life Cycle. Current Topics in Microbiology and Immunology 2015, 389, 243-252.

12. Mailler, E.; Bernacchi, S.; Marquet, R.; Paillart, J. C.; Vivet-Boudou, V.; Smyth, R. P. The Life-Cycle of the HIV-1 Gag-RNA Complex. Viruses 2016, 8, 248.

13. Sundquist, W.I.; Kräusslich, H.-G. HIV-1assembly, budding, and maturation. Cold Spring Harb. Perspect. Med. 2012, 2, a006924.

14. Harden, V.A.; Fauci, A. AIDS at 30: A History; Potomac Books, Inc.: Lincoln, NE, USA, 2012.

15. Lewis, J. M.; Macpherson, P.; Adams, E. R.; Ochodo, E.; Sanda, A.; Taegtmeyer, M. Field accuracy of fourth-generation rapid diagnostic tests for acute HIV-1: a systematic review. AIDS 2015, 29, 2465-2471.

16. Alexander, T. S. Human Immunodeficiency Virus Diagnostic Testing: 30 years of Evolution. Clin. Vaccine Immunol. 2016.

17. Colebunders, R.; Francis, H.; Duma, M. -M.; Groen, G. V. D.; Lebughe, I.; Kapita, H.; Quinn, T. C.; Heyward, W. L.; Piot, P. HIV-1 infection in HIV-l enzyme-linked immunoassay seronegative patients in Kinshasa, Zaire. International Journal of STD \& AIDS 1990, 1, 330-334.

18. Feng, X.; Wangc, J.; Gaod, Z.; Tiana, Y.; Zhanga, L.; Chene, H.; Zhangb, T.; Xiaof, L.; Yaoa, J.; Xinga, W.; Qiua, M.; Jianga, Y. An alternative strategy to Western Blot as a confirmatory diagnostic test for HIV Infection. Journal of Clinical Virology 2016.

19. Auvert, B.; Taljaard, D.; Lagarde, E.; Sobngwi-Tambekou, J.; Sitta, R.; Puren, A. Randomized, controlled intervention trial of male circumcision for reduction of HIV infection risk: The ANRS 1265 trial. PLoS Med. 2005, 2, e298.

20. Günthard, H. F.; Saag, M. S.; Benson, C. A.; Del Rio, C.; Eron, J. J.; Gallant, J. E.; Hoy, J. F.; Mugavero, M. J.; Sax, P. E.; Thompson, M. A. Antiretroviral drugs for treatment and prevention of HIV infection in adults: 2016 recommendations of the International Antiviral Society -USA panel. JAMA 2016, 316, 191-210.

21. Bailey, R. C.; Moses, S.; Parker, C. B.; Agot, K.; Maclean, I.; Krieger, J. N.; Williams, C. F.; Campbell, R. T.; Ndinya-Achola, J. O. Male circumcision for HIV prevention in young men in Kisumu, Kenya: A randomised controlled trial. Lancet 2007, 369, 643-656.

22. Gravatt, L. A. H.; Leibrand, C. R.; Patel, S.; McRae, M. New drugs in the pipeline for the treatment of HIV: A review. Curr. Infect. Dis. Rep. 2017, 19, 42.

23. Sendagire, H.; Easterbrook, P. J.; Nankya, I.; Arts, E.; Thomas D.; Reynolds, S. J. The challenge of HIV-1 antiretroviral resistance in Africa in the era of HAART. AIDS Rev. 2009, 11, 59-70.

24. Ramana, L. N.; Anand, A. R.; Sethuraman, S.; Krishnan, U. M. Targeting strategies for delivery of anti-HIV drugs. Journal of controlled release 2014, 192, 271-283.

25. Lu, D. -Y.; Wu, H. Y.; Yarla, N. S.; Xu, B.; Ding J.; Lu, T. R. HAART in HIV/AIDS treatments: Future trends. Infectious Disorders - Drug Targets, 2018, 18, 15-22.

26. Li, X.; Chan, W. K. Transport, metabolism and elimination mechanisms of anti-HIV agents. Advanced Drug Delivery Reviews 1999, 39, 81-103.

27. Cohen, M. S.; Chen, Y. Q.; McCauley, M.; Gamble, T.; Hosseinipour, M. C.; Kumarasamy, N.; Hakim, J. G.; Kumwenda, J.; Grinsztejn, B.; Pilotto, J. H. Prevention of HIV-1 infection with early antiretroviral therapy. N. Engl. J. Med. 2011, 365, 493-505.

28. Sharifi-Rad, J. Herbal antibiotics: Moving back into the mainstream as an alternative for "superbugs". Cell. Mol. Biol. 2016, 62, 1-2.

29. WHO. In vitro screening of traditional medicines for anti-HIV activity: Memorandum from a WHO meeting. Bull. World Health Organ. 1989, 87, 613-618.

30. WHO. Report of a Who Informal Consultation on Traditional Medicine and AIDS: In Vitro Screening for Anti-HIV Activity; WHO: Geneva, Switzerland, 1989.

31. (a) Cos, P.; Maes, L.; Berghe, D.; V.; Hermans, N.; Pieters, L.; Vlietinck, A. Plant Substances as Anti-HIV Agents Selected According to Their Putative Mechanism of Action. J. Nat. Prod. 2004, 67, 284-293; (b). Kumar, D.; Sharma, P.; Singh, H.; Nepali, K.; Gupta, G.K. Jain, S.K. and Ntie-Kang, F. The value of pyrans 
as anticancer scaffolds in medicinal chemistry. RSC Adv. 2017, 7, 36977; (c). Kumar, D. and Jain, S. K. A Comprehensive Review of N- Heterocycles as Cytotoxic Agents. Curr. Med. Chem. 2016, 23, 4338-4394.

32. (a) Cos, P.; Maes, L.; Vlietinck, A.; Pieters, L. Plant-Derived Leading Compounds for Chemotherapy of Human Immunodefiency Virus (HIV) Infection - An Update (1998-2007). Planta Med. 2008, 74, 1323- 1337; (b) Nepali, K.; Sharma, S.; Kumar, D.; Budiraja, A. and Dhar, K.L. Anticancer Hybrids-A Patent Survey. Recent Pat. Anticancer Drug Discov. 2014, 9, 303-39; (c) Kumar, D. and Bedi, P. M. S. Anti-Inflammatory Agents: Some Recent Advances. Indian Drug. 2009, 46, 675-681; (d) Sharma, P.; Sharma, R.; Rao, H. S. and Kumar, D. Phytochemistry and medicinal attributes of Alstonia scholaris: a review. Int. J. Pharm. Sci. Res. 2015, 6, 505-513; (e) Kumar, D.; Nepali, K.; Bedi, P.M.S.; Kumar, S.; Malik, F. and Jain, S. 4,6-diaryl pyrimidones as constrained chalcone analogues: Design, Synthesis and Evaluation as anti-proliferative agents. Anticancer Agents Med. Chem. 2015, 15, 793-803.

33. (a) Kurapati, K. R. V.; Atluri, V. S.; Samikkannu, T.; Garcia G.; Nair, M. P. N. Natural products as anti-HIV agents and role in HIV-Associated Neurocognitive Disorders (HAND): A brief overview. Front. Microbiol. 2016, 6, 1444; (b) Kumar, D.; Singh, O.; Nepali, K.; Bedi, P. M. S.; Qayum, A.; Singh, S. and Jain, S. K. Naphthoflavones as Anti-proliferative Agents: Design, Synthesis and Biological Evaluation. Anticancer Agents Med. Chem. 2016, 16, 881-90; (c) Kumar, D.; Malik, F.; Bedi, P. M. S. and Jain, S. 2,4-diarylpyrano[3,2-c]chromen-5(4H)-ones as coumarin-chalcone conjugates : Design, synthesis and biological evaluation as apoptosis inducing agents. Chem. Pharm. Bull. 2016, 64, 399-409; (d) Kumar, D.; Singh, G.; Sharma, P.; Qayum, A.; Mahajan, G. and Mintoo, M. J. 4-aryl/heteroaryl-4H-fused pyrans as Anti-proliferative Agents: Design, Synthesis and Biological Evaluation. Anticancer Agents Med. Chem. 2018, 18, 57-73; (e) Kumar, D.; Sharma, P.; Nepali, K.; Mahajan, G.; Mintoo, M. J. and Singh, A. Antitumour, acute toxicity and molecular modeling studies of 4-(pyridin-4-yl)-6-(thiophen- 2-yl) pyrimidin-2(1H)-one against Ehrlich ascites carcinoma and sarcoma-180. Heliyon. 2018, 4, e00661; (f) Guzman, J. D.; Gupta, A.; Bucar, F.; Gibbons, S. and Bhakta, S. Anti-mycobacterials from natural sources: ancient times, antibiotic era and novel scaffolds. Frontiers in Biosci. 2012, 17, 1861-1881.

34. Chaniad, P.; Wattanapiromsakul, C.; Pianwanit, S.; Tewtrakul, S. Anti-HIV-1 integrase compounds from Dioscorea bulbifera and molecular docking study. PHARMACEUTICAL BIOLOGY, 2016.

35. Jiang, C.; Luo, P.; Zhao, Y.; Hong, J.; Morris-Natschke, S. L.; Xu, J.; Chen, C. H.; Lee, K. H.; Gu, Q. Carolignans from the Aerial Parts of Euphorbia sikkimensis and Their Anti-HIV Activity. J. Nat. Prod. 2016.

36. Kalvatchev, Z.; Walder, R.; Garzaro, D. Anti-HIV activity of extracts from Culendula officinalis flowers. Biomed \& Pharmacother 1997, 51, 176-180.

37. Kapewangolo, P.; Tawha, T.; Nawinda, T.; Knott, M.; Hans, R. Scelectium tortuosum demonstrates in vitro anti-HIV and free radical scavenging activity. South African Journal of Botany 2016, 106, 140-143.

38. Ito, J.; Chang, F. R.; Wang, H. K.; Park, Y. K.; Ikegaki, M.; Kilgore N.; Lee, K. H. Anti-AIDS Agents. 48. Anti-HIV Activity of Moronic Acid Derivatives and the New Melliferone-Related Triterpenoid Isolated from Brazilian Propolis. J. Nat. Prod. 2001, 64, 1278-1281.

39. Cassels, B. K.; Asencio, M. Anti-HIV activity of natural triterpenoids and hemisynthetic derivatives 2004-2009. Phytochem. Rev. 2010.

40. Cheng, Y. B.; Liu, F. J.; Wang, C. H.; Hwang, T. L.; Tsai, Y. F.; Yen, C. H.; Wang, H. C.; Tseng, Y. H.; Chien, C. T.; Chen, Y. M. A.; Chang, F. R.; Wu, Y. C. Bioactive Triterpenoids from the Leaves and Twigs of Lithocarpus litseifolius and L. corneus. Planta Med. 2018, 84, 49-58.

41. Kapewangolo, P.; Kandawa-Schulz, M.; Meyer, D. Anti-HIV Activity of Ocimum labiatum Extract and Isolated Pheophytin-A. Molecules 2017.

42. Sharifi-Rad, M.; Varoni, E. M.; Salehi, B.; Sharifi-Rad, J.; Matthews, K. R.; Ayatollahi, S. A.; Kobarfard, F.; Ibrahim, S. A.; Mnayer, D.; Zakaria, Z. A. Plants of the genus Zingiber as a source of bioactive phytochemicals: From tradition to pharmacy. Molecules 2017, 22, 2145.

43. Sharifi-Rad, J.; Salehi, B.; Schnitzler, P.; Ayatollahi, S.; Kobarfard, F.; Fathi, M.; Eisazadeh, M.; Sharifi-Rad, M. Susceptibility of herpes simplex virus type 1 to monoterpenes thymol, carvacrol, p-cymene and essential oils of Sinapis arvensis L., Lallemantia royleana Benth. and Pulicaria vulgaris Gaertn. Cell. Mol. Biol. 2017, 63, 42-47.

44. Salehi, B.; Zucca, P.; Sharifi-Rad, M.; Pezzani, R.; Rajabi, S.; Setzer, W.; Varoni, E.; Iriti, M.; Kobarfard, F.; Sharifi-Rad, J. Phytotherapeutics in cancer invasion and metastasis. Phytother. Res. 2018, 1-25.

45. Sharifi-Rad, J.; Hoseini-Alfatemi, S.; Sharifi-Rad, M.; Miri, A. Phytochemical screening and antibacterial activity of different parts of the Prosopis farcta extracts against methicillin-resistant Staphylococcus aureus (MRSA). Min. Biotecnol. 2014, 26, 287-293.

46. Sharifi-Rad, M.; Tayeboon, G.; Sharifi-Rad, J.; Iriti, M.; Varoni, E.; Razazi, S. Inhibitory activity on type 2 diabetes and hypertension key-enzymes, and antioxidant capacity of Veronica persica phenolic-rich extracts. Cell. Mol. Biol. 2016, 62, 80-85. 
47. Sharifi-Rad, J.; Mnayer, D.; Tabanelli, G.; Stojanovic'-Radic', Z.; Sharifi-Rad, M.; Yousaf, Z.; Vallone, L.; Setzer, W.; Iriti, M. Plants of the genus Allium as antibacterial agents: From tradition to pharmacy. Cell. Mol. Biol. 2016, 62, 57-68.

48. Bagheri, G.; Mirzaei, M.; Mehrabi, R.; Sharifi-Rad, J. Cytotoxic and antioxidant activities of Alstonia scholaris, Alstonia venenata and Moringa oleifera plants from India. Jundishapur J. Nat. Pharm. Prod. 2016, 11, e31129.

49. Farnsworth, N. R. The role of ethnopharmacology in drug development. Bioactive Compounds from Plants, Chadwick, D. J.; Marsh, J., Eds., John Wiley \& Sons: New York, 1990, 2-21.

50. Clercq, E. D. Antiviral Therapy for Human Immunodeficiency Virus Infections. Clinical Microbiology Reviews 1995, 8, 200-239.

51. Blanco, J. L.; Whitlock, G.; Milinkovic, A.; Moyle, G. HIV integrase inhibitors: A new era in the treatment of HIV. Expert Opin. Pharmacother. 2015, 16, 1313-1324.

52. Andreola, M. L.; Soultrait, V. R. D.; Fournier, M.; Parissi, V.; Desjobert C.; Litvak, S. HIV-1 integrase and RNase H activities as therapeutic targets. Expert Opin. Ther. Targets 2002, 6, 433-446.

53. Kanyara, J. N.; Njagi, E. N. M. Anti-HIV-1 Activities in Extracts From Some Medicinal Plants as Assessed in an in vitro Biochemical HIV-1 Reverse Transcriptase Assay. Phytother. Res. 2005, 19, 287-290.

54. Painter, G.; Almond, M.; Mao, S.; Liotta, D. Biochemical and mechanistic basis for the activity of nucleoside analogue inhibitors of HIV reverse transcriptase. Curr. Top. Med. Chem. 2004, 4, 1035-1044.

55. Ng, T. B.; Huang, B.; Fong W. P.; Yeung, H. W. Anti-Human Immunodeficiency Virus (Anti-HIV) natural products with special emphasis on hiv reverse transcriptase inhibitors. Life Sciences 1997, 61, 933-949.

56. Deng, X.; Zhang, Y.; Jiang, F.; Chen, R.; Peng, P.; Wen, B.; Liang, J. The Chinese herb-derived Sparstolonin B suppresses HIV-1 transcription. Virology Journal 2015.

57. Ma, C. M.; Nakamura, N.; Hattori, M.; Kakuda, H.; Qiao, J. C.; Yu, H. L. Inhibitory Effects on HIV-1 Protease of Constituents from the Wood of Xanthoceras sorbifolia. J. Nat. Prod. 2000, 63, 238-242.

58. Konvalinka, J.; Kräusslich, H.-G.; Müller, B. Retroviral proteases and their roles in virion maturation. Virology 2015, 479-480, 403-417.

59. Wei, Y.; Ma, C.-M.; Chen, D.-Y.; Hattori, M. Anti-HIV-1 protease triterpenoids from Stauntonia obovatifoliola Hayata subsp. Intermedia. Phytochemistry 2008, 69, 1875-1879.

60. Park, J. C.; Hur, J. M.; Park, J. G.; Hatano, T.; Yoshida, T.; Miyashiro, H.; Min, B. S.; Hattori, M. Inhibitory Effects of Korean Medicinal Plants and Camelliatannin $\mathrm{H}$ from Camellia japonica on Human Immunodeficiency Virus Type 1 Protease. Phytother. Res. 2002, 16, 422-426.

61. Burke, B. P.; Boyd, M. P.; Impey, H.; Breton, L. R.; Bartlett, J. S.; Symonds, G. P.; Hütter, G. CCR5 as a Natural and Modulated Target for Inhibition of HIV. Viruses 2014, 6, 54-68.

62. Jiang, S.; Zhao, Q.; Debnath, A. K. Peptide and Non-peptide HIV Fusion Inhibitors. Current Pharmaceutical Design 2002, 8, 563-580.

63. Quinones-Mateu, M. E.; Schols, D. Virus-inhibitory peptide: a natural HIV entry inhibitor in search for a formal target in the viral genome. AIDS 2011, 25, 1663-1664.

64. Balzarini, J.; Neyts, J.; Schols, D.; Hosoya, M.; Damme, E. V.; Peumans, W.; Clercq, E. D. The mannose-specific plant lectins from Cymbidium hybrid and Epipactis helleborine and the (N-acetylglucosamine)n-specific plant lectin from Urtica dioica are potent and selective inhibitors of human immunodeficiency virus and cytomegalovirus replication in vitro. Antiviral Research 1992, 18, 191-207.

65. Vlietinck, A. J.; Bruyne, T. D.; Apers, S.; Pieters, L. A. Plant-Derived Leading Compounds for Chemotherapy of Human Immunodeficiency Virus (HIV) Infection. Planta Medica. 1998, 64, 97-109.

66. Matsuda, K.; Hattori, S.; Komizu, Y.; Kariya, R.; Ueoka, R.; Okada, S. Cepharanthine inhibited HIV-1 cell-cell transmission and cell-free infection via modification of cell membrane fluditiy. Bioorganic $\mathcal{E}$ Medicinal Chemistry Letters 2014, 24, 2115-2117.

67. Uttekar, M. M.; Das, T.; Pawar, R. S.; Bhandari, B.; Menon, V.; Nutan; Gupta, S. K.; Bhat, S. V. Anti-HIV activity of semisynthetic derivatives of andrographolide and computational study of HIV-1 gp120 protein binding. European Journal of Medicinal Chemistry 2012, 56, 368-374.

68. Kumar, R. A.; Sridevi, K.; Kumar, N. V.; Nanduri, S.; Rajagopal, S. Anticancer and immunostimulatory compounds from Andrographis paniculata. Journal of Ethnopharmacology 2004, 92, 291-295.

69. Jr, J. D. A.; Lien, E. J. Traditional Chinese Medicine: Scientific Basis for Its Use. The Royal Society of Chemistry 2013.

70. Chao, W.-W.; Lin, B.-F. Isolation and identification of bioactive compounds in Andrographis paniculata (Chuanxinlian). Chinese Medicine 2010, 5, 17.

71. Varma, A.; Padh, H.; Shrivastava, N. Andrographolide: A New Plant-Derived Antineoplastic Entity on Horizon. eCAM 2009, 1-9. 
72. Jayakumar, T.; Hsieh, T. Y.; Lee, J. J.; Sheu, J. R. Experimental and Clinical Pharmacology of Andrographis paniculata and Its Major Bioactive Phytoconstituent Andrographolide. Evidence-Based Complementary and Alternative Medicine 2013.

73. Wang, C. K. L.; Clark, R. J.; Harvey, P. J.; Rosengren, K. J.; Cemazar, M.; Craik, D. J. The Role of Conserved Glu Residue on Cyclotide Stability and Activity: A Structural and Functional Study of Kalata B12, a Naturally Occurring Glu to Asp Mutant. Biochemistry 2011, 50, 4077-4086.

74. Mfopa, A. N.; Coron, A.; Eloh, K.; Tramontano, E.; Frau, A.; Boyom, F. F.; Caboni, P.; Tocco, G. Uvaria angolensis as a promising source of inhibitors of HIV-1 RT-associated RNA-dependent DNA polymerase and RNase H functions. Natural Product research 2018, 32, 640-647.

75. Sanna, C.; Scognamiglio, M.; Fiorentino, A.; Corona, A.; Graziani, V.; Caredda, A.; Cortis, P.; Montisci, M.; Ceresola, E. R.; Canducci, F.; Poli, F.; Tramontano, E.; Esposito, F. Prenylated phloroglucinols from Hypericum scruglii, an endemic species of Sardinia (Italy), as new dual HIV-1 inhibitors effective on HIV-1 replication. PLOS ONE 2018, 13, e0195168.

76. Liang, Q.; Yu, F.; Cui, X.; Duan, J.; Wu, Q.; Nagarkatti, P.; Fan, D. Sparstolonin B suppresses lipopolysachharide-induced inflammation in human umbilical vein endothelial cells. Arch. Pharm. Res. 2013, 36, 890-896.

77. Huerta-Reyes, M.; Basualdo, M. D. C.; Abe, F.; Jimenez-Estrada, M.; Soler, C.; Reyes-Chilpa, R. HIV-1 Inhibitory Compounds from Calophyllum brasiliense Leaves. Biol. Pharm. Bull. 2004, 27, 1471-1475.

78. Matthee, G.; Wright, A. D.; Konig, G. M. HIV reverse transcriptase inhibitors of natural origin. Planta Medica. 1999, 65, 493-506.

79. Lee, T. T.-Y.; Kashiwada, Y.; Huang, L.; Snider, J.; Cosentino, M.; Lee, K.-H. Suksdorfin: an Anti-HIV Principle from Lomutium suksdorfii, its Structure-Activity Correlation with Related Coumarins, and Synergistic Effects with Anti-AIDS Nucleosides. Bioorganic \& Medicinal Chemistry 1994, 2, 1051-1056.

80. Hudson, J. B.; Graham, E. A.; Harris, L.; Ashwwd-Smith, M. J. The unusual Uva-dependent antiviral properties of the furoisocoumarin, coriandrin. Photochemistry and Photobiology 1993, 57, 491-496.

81. Hu, C. Q.; Chen, K.; Shi, Q.; Kilkuskie, R. E.; Cheng, Y. C.; Lee, K. H. Anti-aids agents, 10. Acacetin-7-O- $\beta$-D-galactopyranoside, an anti-HIV principle from Chrysanthemum morifolium and a structure-activity correlation with some related flavonoids. J. Nat. Prod. 1994, 57, 42-51.

82. Wang, J. N.; Hou, C. Y.; Liu, Y. L.; Lin, L. Z.; Gil, R. R.; Cordell, G. A. Swertifrancheside, an HIV-reverse transcriptase inhibitor and the first flavone-xanthone dimer from Swertia francheitiana. J.Nat. Prod. 1994, 57, 211-217.

83. Boyd, M. R.; Hallock, Y. F.; Cardellina, J. H.; Manfredi, K. P.; Blunt, J. W.; McMahon, J. B.; Buckheit, R. W.; Jr.; Bringmann, G.; Schiiffer, J. M.; Cragg, G. M.; Thomas, D. W.; Jato, J. G. Anti-HIV Michellamines from Ancistrocladus korupensis. J. Med. Chem. 1994, 37, 1740-1745.

84. Ingolfsdottir, K.; Hjalmarsdottir, M. A.; Sigurdsson, A.; Gudjonsdottir, G. A.; Brynjolfsdottir, A.; Steingrimsson, O. In vitro susceptibility of Helicobacter pylori to protolichesterinic acid from the lichen Cetraria islandica. Antimicrob. Agents Chemother. 1997, 41, 215-217.

85. Nakane, H.; Arisawa, M.; Fujita, A.; Koshimura, S.; Ono, K. Inhibition of HIV reverse transcriptase activity by some phloroglucinol derivatives. FEBS Lett. 1991, 286, 83-85.

86. Xiao, W. L.; Tian, R. R.; Pu, J. X.; Li, X.; Wu, L.; Lu, Y.; Li, S. H.; Li, R. T.; Zheng, Y. T.; Zheng, Q. T.; Sun, H. D. Triterpenoids from Schisandra lancifolia with anti-HIV-1 activitiy. J. Nat. Prod. 2006, 69, 277-279.

87. Erickson, K. L.; Beutler, J. A.; Cardellina, J. H.; McMahon, J. B.; Newman, D. J.; Boyd, M. R. A novel phorbol ester from Excoecaria agallocha. J. Nat. Prod. 1995, 58, 769-772.

88. Chen, K.; Shi, Q.; Kashiwada, Y.; Zhang, D. C; Hu, C. Q.; Jin, J. Q.; Nozaki, H.; Kilkuskie, R. E.; Tramontano, E.; Mcphail, D. R.; Cheng, Y. C.; Mcphail, A. T.; Lee, K. H. Anti-AIDS agents, 6. Salaspermic acid, an anti-HIV principle from Tripterygium wilfordii, and the structure activity correlation with its related compounds. J. Nat. Prod. 1992, 55, 340-346.

89. Oksuz, S.; Gurek, F.; Gil, R. R.; Pengsuparp, T.; Pezzuto, J. M.; Cordell, G. A. 4 diterpene esters from Euphorbia myrsinites. Phyto- chemistry 1995, 38, 1457-1462.

90. Chinsembu, K. C.; Hedimbi, M. A survey of plants with anti-HIV active compounds and their modes of action. Medical Journal of Zambia 2009, 36, 178-186.

91. Chang, R. S.; Ding, L.; Chen, G. Q.; Pan, Q. C.; Zhao, J. L.; Smith, K. M. Dehydroandrographolide succinic acid monoester as an inhibitor against the human immunodeficiency virus. Proc. Sot. Exp. Biol. Med. 1991, 197, 59-66.

92. Ito, M.; Sato, A.; Hirabayashi, K.; Tanabe, F.; Shigeta, S.; Baba, M.; Clercq, E. D.; Nakashima, H.; Yamamoto, $\mathrm{N}$. Mechanism of inhibitory effect of glycyrrhizin on replication of human immunodeficiency virus (HIV). Antiviral Res. 1988, 10, 289-298. 
93. Konoshima, T.; Kashiwada, Y.; Takasaki, M.; Kozuka, M.; Yasuda, I.; Cosentino, L. M.; Lee, K. H. Cucurbitacin F derivatives, anti-HIV principles from Cowania mexicana. Bioorg. Med. Chem. Lett. 1994, 4, 1323-1326.

94. Chen, K.; Shi, Q. A.; Fujioka, T.; Zhang, D. C.; Hu, C. Q.; Jin, J. Q.; Kilkuskie, R. E.; Lee, K. H. Anti-aids agents, 4. Tripterifordin, a novel anti-HIV principle from Tripterygium wilfordii: Isolation and structural elucidation. J. Nat. Prod. 1992, 55, 88-92.

95. Pengsuparp, T.; Cai, L.; Fong, H. H.; Kinghorn, A. D.; Pezzuto, J. M.; Wani, M. C.; Wall, M. E. Pentacyclic trirepenes derived from Maprounea africana are potent inhibitors of HIV-1 reverse transcriptase. J. Nat. Prod. 1994, 57, 415-418.

96. Fujioka, T.; Kashiwada, Y.; Kilkuskie, R. E.; Cosentino, L. M.; Ballas, L. M.; Jiang, J. B.; Janzen, W. P.; Chen, I. S.; Lee, K. H. Anti-aids agents, 11. Betulinic acid and platanic acid as anti-HIV principles from Syzigium claviflorum, and the anti-HIV activity of structurally related triterpenoids. J. Nat. Prod. 1994, 57, 243-247.

97. Hayashi, K.; Kamiya, M.; Hayashi, T. Virucidal effects of steam distillate from Houttuynia cordata and its components on HSV-1, influenza virus, and HIV. Planta Med. 1995, 61, 237-241.

98. Li, B. Q.; Fu, T.; Yan, Y. D.; Baylor, N. W.; Ruscetti, F. W.; Kung, H. F. Inhibition of HIV infection by baicalin-a flavonoid compound purified from Chinese herbal medicine. Cell. Mol. Biol. Res. 1993, 39, 119-124.

99. Beutler, J. A.; Cardellina, J. H.; McMahon, J. B.; Boyd, M. R.; Cragg, G. M. Anti-HIV and cytotoxic alkaloids from Buchenavia capitata. J. Nat. Prod. 1992, 55, 207-213.

100. Tang, X.; Chen, H.; Zhang, X.; Quan, K.; Sun, M. Screening anti-HIV Chinese material mediea with HIV and equine infectious anemic virus reverse transcriptase. J. Tradit. Chin. Med. 1994, 14, 10-13.

101. Patil, A. D.; Freyer, A. J.; Eggleston, D. S.; Haltiwanger, R. C.; Bean, M. F.; Taylor, P. B.; Caranfa, M. J.; Breen, A. L.; Bartus, H. R.; Johnson, R. K. The inophyllums, novel inhibitors of HIV-1 reverse transcriptase isolated from Malaysian tree, Calophyllum inophyllum Linn. J. Med. Chem. 1993, 36, 4131-4138.

102. Sharma, B. R.; Rattan, R. K.; Sharma, P. Marmeline, an alkaloid, and other components of unripe fruits of Aegle marmelos. Phytochemistry 1981, 20, 2606-2607.

103. Harkar, S.; Razdan, T. K.; Waight, E. S. Steroids, chromone and coumarins from Angelica officinalis. Phytochemistry 1984, 23, 419-426.

104. Cheng, H. Y.; Lin, T. C.; Yang, C. M.; Wang, K. C.; Lin, L. T.; Lin, C. C. Putranjivain A from Euphorbia jolkini inhibits both virus entry and late stage replication of herpes simplex virus type 2 in vitro. Journal of Antimicrobial Chemotherapy 2004, 53, 577-583.

105. Hatano, T.; Ogawa, N.; Kira, R.; Yasuhara, T.; Okuda, T. Tannins of cornaceous plants. I. Cornusiins A, B and $\mathrm{C}$, dimeric monomeric and trimeric hydrolysable tannins from Cornus officinalis, and orientation of valoneoyl group in related tannins. Chem. Pharm. Bull. (Tokyo) 1989, 37, 2083-2090.

106. Ogata, T.; Higuchi, H.; Mochida, S.; Matsumoto, H.; Kato, A.; Endo, T.; Kaji, A.; Kaji, H. HIV-1 reverse transcriptase inhibitor from Phyllanthus niruri. AIDS Res. Hum. Retroviruses 1992, 8, 1937-1944.

107. Kreis, W.; Kaplan, M. H.; Freeman, J.; Sun, D. K.; Sarin, P. S. Inhibition of HIV replication by Hyssop officinalis extracts. Antiviral Res. 1990, 14, 323-337.

108. Naser, B.; Bodinet, C.; Tegtmeier, M.; Lindequist, U. Thuja occidentalis (Arbor vitae): A review of its pharmaceutical, pharmacological and clinical properties. Evid Based Complement Alternat Med. 2005, 2, 69-78.

109. Tabba, H. D.; Chang, R. S.; Smith, K. M. Isolation, purification, and partial characterization of Prunellin, an Anti-HIV component from aqueous extracts of Prunella vulgaris. Antiviral Res. 1989, 11, 263-273.

110. Ngan, F.; Chang, R. S.; Tabba, H. D.; Smith, K. M. Isolation, purification and partial characterization of an active anti-HIV compound from the Chinese medicinal herb Viola yedoensis. Antiviral Res. 1988, 10, $107-116$.

111. Wang, J. P.; Raung, S. L.; Lin, C. N.; Teng, C. M. Inhibitory effect of norathyriol, a xanthone from Tripterospermum lanceolatum, on cutaneous plasma extravasation. European Journal of Pharmacology. 1994, $251,35-42$.

112. Ulubelen, A.; Gil, R. R.; Cordell, G. A.; Mericli, A. H.; Mericli, F. Prenylated lignans from Haplophyllum ptilostylum. Phytochemistry 1995, 39, 417-422.

113. Fujihashi, T.; Hara, H.; Sakata, T.; Mori, K.; Higuchi, H.; Tanaka, A.; Kaji, H.; Kaji, A. Anti-human immunodeficiency virus (HIV) activities of halogenated gomisin J derivatives, new nonnucleoside inhibitors of HIV type 1 reverse transcriptase. Antimicrob Agents Chemother 1995, 39, 2000-2007.

114. Schröder, H. C.; Merz, H.; Steffen, R.; Müller, W. E. G. Differential in vitro Anti-HIV Activity of Natural Lignans. Z. Naturforsch. 1990, 45c, 1215-1221.

115. Talpir, R.; Rudi, A.; Kashman, Y.; Hizi, A. Three new sesquiterpene hydroquinones from marine origin. Tetrahedron 1994, 50, 4179-4184. 
116. Jimenez, C.; Quinoa, E.; Adamczeski, M.; Hunter, L. M.; Crews, P. Novel sponge-derived amino acids. 12. Tryptophan-derived pigments and accompanying sesterterpenes from Fascapilsinopsis reticulata. J. Org. Chem. 1991, 56, 3403-3410.

117. Loya, S.; Tal, R.; Hizi, A.; Issacs, S.; Kashman, Y.; Loya, Y. Hexprenoid hydroquinones, novel inhibitors of the reverse transcriptase of human immunodeficiency virus type 1. J. Nat. Prod. 1993, 56, 2120-2125.

118. Inman, W. D.; Johnson, M. O’N.; Crews, P. Novel marine sponge alkaloids. 1. Plakinidine A and B, anthelmintic active alkaloids from a Plakortis sponge. J. Am. Chem. Soc. 1990, 112, 1-4.

119. Tymiak, A. A.; Jr, K. L. R. Structurees of kelletinins 1 and 2, antibacterial metabolites of the marine mollusk Kelletia kelletii. J. Am. Chem. Soc. 1983, 105, 7396-7401.

120. Silvestri, I.; Albonici, L.; Ciotti, M.; Lombardi, M. P.; Sinibaldi, P.; Manzari, V.; Orlando, P.; Carretta, F.; Strazzullo, G.; Grippo, P. Antimitotic and antiviral activities of Kelletinin A in HTLV-1 infected MT2 cells. Experientia 1995, 51, 1076-1080.

121. Chaudhuri, S. K.; Fullas, F.; Brown, D. M.; Wani, M. C.; Wall, M. E.; Cai, L.; Mar, W.; Lee, S. K.; Luo, Y.; Zaw, K.; Fong, H. H. S.; Pezzuto, J. M.; Kinghorn, A. D. Isolatioon and structural elucidation of pentacyclic triterpenoids from Maprounea africana. J. Nat. Prod. 1995, 58, 1-9.

122. Pani, A.; Marongiu, M. E. Anti-HIV integrase drugs how far from the shelf. Curr. Pharm. Des. 2000, 6, 569-584.

123. Ghosh, S.; Ahire, M.; Patil, S.; Jabgunde, A.; Dusane, M. B.; Joshi, B. N.; Pardesi, K.; Jachak, S.; Dhavale, D. D.; Chopade, B. A. Antidiabetic activity of Gnidia glauca and Dioscorea bulbifera: potent amylase and glucosidase inhibitors. J Evid Based Complement Altern Med. 2012, 1-9.

124. Wang, J. M.; Ji, L. L.; Branford-White, C. J.; Wang, Z. Y.; Shen, K. K.; Liu, H.; Wang, Z. T. Antitumor activity of Dioscorea bulbifera L. rhizome in vivo. Fitoterapia 2012, 83, 388-394.

125. Teponno, R. B.; Tapondjou, A. L.; Gatsing, D.; Djoukeng, J. D.; AbouMansour, E.; Tabacchi, R.; Tane, P.; Stoekli-Evans, H.; Lontsi, D. Bafoudiosbulbins A, and B, two anti-salmonellal clerodane diterpenoids from Dioscorea bulbifera L. var sativa. Phytochemistry 2006, 67, 1957-1963.

126. Mbiantcha, M.; Kamanyi, A.; Teponno, R. B.; Barreca, M. L.; Villa, L.; Monforte, P.; Chimirri, A. Analgesic and anti-inflammatory properties of extracts from the bulbils of Dioscorea bulbifera L. var sativa (Dioscoreaceae) in mice and rats. Evid Based Complement Alternat Med. 2011, 2011, 1-9.

127. Ahmed, Z.; Chishti, M. Z.; Johri, R. K.; Bhagat, A.; Gupta, K. K.; Ram, G. Antihyperglycemic and antidyslipidemic activity of aqueous extract of Dioscorea bulbifera tubers. Diabetol Croat. 2009, 38, 63-72.

128. Panthong, P.; Bunluepuech, K.; Boonnak, N.; Chaniad, P.; Pianwanit, S.; Wattanapiromsakul, C.; Tewtrakul, S. Anti-HIV-1 integrase activity and molecular docking of compounds from Albizia procera bark. Pharm Biol. 2015, 53, 1861-1866.

129. Kokila, K.; Priyadharshini, S. D.; Sujatha, V. Phytopharmacological properties of Albizia species: A review. Int. J. Pharm. Pharm. Sci. 2013, 5, 70-3.

130. Yadav, S. K.; Batra, J. K. Mechanism of anti-HIV activity of ribosome inactivating protein, saporin. Protein Pept. Lett. 2015, 22, 497-503.

131. Puri, M.; Kaur, I.; Kanwar, R. K.; Gupta, R. C.; Chauhan, A.; Kanwar, J. R. Ribosome Inactivating Proteins (RIPs) from Momordica charantia for Anti Viral Therapy. Current Molecular Medicine 2009, 9, 1080-1094.

132. Sun, Y.; Huang, P. L.; Li, J. J.; Huang, Y. Q.; Zhang, L.; Huang, P. L.; Lee-Huang, S. Anti-HIV agent MAP30 modulates the expression profile of viral and cellular genes for proliferation and apoptosis with Kaposi's sarcoma-associated virus. Biochem. Biophys. Res. Commun. 2001, 287, 983-994.

133. Zhao, W.; Feng, D.; Sun, S.; Han, T.; Sui, S. The anti-viral protein of trichosanthin penetrates into human immunodeficiency virus type 1. Acta. Biochim. Biophys. Sin. 2010, 91-97

134. Au, T. K.; Collins, R. A.; Lam, T. L.; Ng, T. B.; Fong, W. P.; Wan, D. C. C. The plant ribosome inactivating proteins luffin and saporin are potent inhibitors of HIV-1 integrase. FEBS Lett. 2000, 471, 169-172.

135. Kohl, N. E.; Emini, E. A.; Schiief, W. A. Active human immunodeficiency virus protease is required for viral infectivity. Proc. Natl. Acad. Sci. USA 1988, 85, 4686-4690.

136. Katoch, I.; Ikawa, Y.; Yoshinaka, Y. Retrovirus protease characterized as a dimeric aspartic proteinase. J. Virol. 1989, 63, 2226-2232.

137. Han, L.; Hatano, T.; Yoshida, T.; Okuda, T. Tannins of Theaceous plants. V. Camelliatannins F, G and H, three new tannins from Camellia japonica L. Chem Pharm Bull 1994, 42, 1399-1409.

138. Mcquade, T. J.; Tomasselli, A. G.; Liu, L. A synthetic HIV-1 protease inhibitor with antiviral activity arrests HIV-like particle maturation. Science 1990, 247, 454-456.

139. Meek, T. D.; Dayton, B. D.; Metcalf, B. W. Human immunodeficiency virus 1 protease expressed in Escherichia coli behaves as a dimeric aspartic protease. Proc. Natl. Acad. Sci. USA. 1989, 86, 1841-1845.

140. Dantanarayana, A.P.; Kumar, N.S.; Muthukuda, P.M.; Wazzeer, M. I. M. A lupine derivative and the ${ }^{13} \mathrm{C}$ NMR chemical shifts of some lupanols from Pleurostylia opposita. Phytochemistry 1982, 21, 2065-2068. 
141. Ikuta, A. The triterpenes from Stauntonia hexaphylla callus tissues and their biosynthetic significance. J. Nat. Prod. 1989, 52, 623-628.

142. Pech, G. G.; Brito, W. F.; Mena, G. J.; Quijano, L. Constituents of Acacia cedilloi and Acacia gaumeri. Revised structure and complete NMR assignments of resinone. Z. Naturforsch. 2002, 57c, 773-776.

143. Wenkert, E.; Baddeley, G. V.; Burfit, I. R.; Moreno, L. N. Carbon-13 nuclear magnetic resonance spectroscopy of naturally -occuring substances. LVII. Triterpenes related to lupine and hopane. Org. Magn. Reson. 1978, 11, 343-377.

144. Ikuta, A.; Itokawa, H. Triterpenoids of Akebia quinata callus tissue. Phytochemistry 1986, 25, 1625-1628.

145. Seo, S.; Tomita, Y.; Tori, K. Carbon-13 NMR spectra of urs-12-enes and application to structural assignments of components of Isodon japonicus hara tissue cultures. Tetrahedron Lett. 1975,7-10.

146. Hakkinen, S. H.; Karenlampi, S. O.; Heinonen, I. M.; Mykkanen, H. M.; Torronen, A. R. Content of flavonols quercetin, myricetin, and kaempferol in 25 edible berries. J. Agric. Food Chem. 1999, 47, 2274-2279.

147. Liang, S.; Tian, J.-M.; Feng, Y.; Liu, X.-H.; Xiong, Z.; Zhang, W.-D. Flavonoids from Daphne aurantiaca and Their Inhibitory Activities against Nitric Oxide Production. Chem. Pharm. Bull. 2011, 59, 653-656.

148. Venkatalakshmi, P.; Vadivel, V.; Brindha, P. Role of phytochemicals as immunomodulatory agents: A review. International Journal of Green Pharmacy 2016, 10.

149. Sell, S. Immunomodulation. In: Immunology Immunopathology and Immunity. New York: Elsevier Science Publishing Company, Inc. 1987, 655-683.

150. Agarwal, S. S.; Singh, V. K. Immunomodulators: A review of studies on Indian medicinal plants and synthetic peptides. Part-I: Medicinal plants. Proc. Indian Nation Sci. Acad. B 1999, 65, 179-204.

151. Holtmeier, W.; Kabelitz, D. Gammadelta T cells link innate and adaptive immune responses. Chem. Immunol. Allergy 2005, 86, 151-183.

152. Harborne, J. B. Phytochemical Methods. London: Chapman and Hall, Ltd. 1973, 149-188.

153. Okwu, D. E. Phytochemicals and vitamin content of indigenous spices of South Eastern. Nig. J. Sust. Agric. Environ. 2004, 6, 30-37.

154. Li, F.; Wang, H. D.; Lu, D. X.; Wang, Y. P.; Qi, R. B.; Fu, Y. M.; et al. Neutral sulfate berberine modulates cytokine secretion and increases survival in endotoxemic mice. Acta. Pharmacol. Sin. 2006, 27, 1199-1205.

155. Mark, W.; Schneeberger, S.; Seiler, R.; Stroka, D. M.; Amberger, A.; Offner, F.; et al. Sinomenine blocks tissue remodeling in a rat model of chronic cardiac allograft rejection. Transplantation 2003, 75, 940-945.

156. Sunila, E. S.; Kuttan, G. Immunomodulatory and antitumor activity of Piper longum Linn. and piperine. J. Ethnopharmacol. 2004, 90, 339-346.

157. Lai, J. H.; Ho, L. J.; Kwan, C. Y.; Chang, D. M.; Lee, T. C. Plant alkaloid tetrandrine and its analog block CD28-costimulated activities of human peripheral blood $\mathrm{T}$ cells: Potential immunosuppressants in transplantation immunology. Transplantation 1999, 68, 1383-1392.

158. Chiang, L. C.; Ng, L. T.; Chiang, W.; Chang, M. Y.; Lin, C. C. Immunomodulatory activities of flavonoids, monoterpenoids, triterpenoids, iridoid glycosides and phenolic compounds of Plantago species. Planta Med. 2003, 69, 600-604.

159. Akbay, P.; Basaran, A. A.; Undeger, U.; Basaran, N. In vitro immunomodulatory activity of flavonoid glycosides from Urtica dioica L. Phytother Res. 2003, 17, 34-37.

160. Garcia, D.; Leiro, J.; Delgado, R.; Sanmartín, M. L.; Ubeira, F. M. Mangifera indica L. extract (Vimang) and mangiferin modulate mouse humoral immune responses. Phytother Res. 2003, 17, 1182-1187.

161. Seeram, N. P.; Adams, L. S.; Henning, S. M.; Niu, Y.; Zhang, Y.; Nair, M. G.; et al. In vitro anti-proliferative, apoptotic and antioxidant activities of punicalagin, ellagic acid and a total pomegranate tannin extract are enhanced in combination with other polyphenols as found in pomegranate juice. J. Nutr. Biochem. 2005, 16, 360-367.

162. Ranjan, D.; Johnston, T. D.; Wu, G.; Elliott, L.; Bondada, S.; Nagabhushan, M. Curcumin blocks cyclosporine A-resistant CD28 costimulatory pathway of human T-cell proliferation. J. Surg. Res. 1998, 77, 174-178.

163. Reddy, D. B.; Reddanna, P. Chebulagic acid (CA) attenuates LPS-induced inflammation by suppressing NF-kappaB and MAPK activation in RAW 264.7 macrophages. Biochem. Biophys. Res. Commun. 2009, 381, 112-117.

164. Lee, S. I.; Kim, B. S.; Kim, K. S.; Lee, S.; Shin, K. S.; Lim, J. S. Immune-suppressive activity of punicalagin via inhibition of NFAT activation. Biochem. Biophys. Res. Commun. 2008, 371, 799-803.

165. Chang, S. L.; Chiang, Y. M.; Chang, C. L.; Yeh, H. H.; Shyur, L. F.; Kuo, Y. H. Flavonoids, centaurein and centaureidin, from Bidens pilosa, stimulate IFN-gamma expression. J. Ethnopharmacol. 2007, 112, 232-236.

166. Abd-Alla, H. I.; Moharram, F. A.; Gaara, A. H.; El-Safty, M. M. Phytoconstituents of Jatropha curcas L. leaves and their immunomodulatory activity on humoral and cellmediated immune response in chicks. $\mathrm{Z}$. Naturforsch. C 2009, 64, 495-501. 
167. Punturee, K.; Wild, C. P.; Kasinrerk, W.; Vinitketkumnuen, U. Immunomodulatory activities of Centella asiatica and Rhinacanthus nasutus extracts. Asian Pac. J. Cancer Prev. 2005, 6, 396-400.

168. Ablise, M.; Leininger-Muller, B.; Wong, C. D.; Siest, G.; Loppinet, V.; Visvikis, S. Synthesis and in vitro antioxidant activity of glycyrrhetinic acid derivatives tested with the cytochrome P450/NADPH system. Chem. Pharm. Bull. (Tokyo) 2004, 52, 1436-1439.

169. Pace, G. W.; Leaf, C. D. The role of oxidative stress in HIV disease. Free Radic. Biol. Med. 1995, 19, 523-528.

170. Olinski, R.; Gackowski, D.; Foksinski, M.; Rozalski, R.; Roszkowski, K.; Jaruga, P. Oxidative DNA damage: assessment of the role in carcinogenesis, atherosclerosis, and acquired immunodeficiency syndrome. Free Radic. Biol. Med. 2002, 33, 192-200.

171. Torre, D.; Pugliese, A.; Speranza, F. Role of nitric oxide in HIV-1 infection: friend or foe? Lancet Infect. Dis. 2002, 2, 273-280.

172. Kinscherf, R.; Fischbach, T.; Mihm, S.; Roth, S.; HohenhausSievert, E.; Weiss, C.; Edler, L.; Bartsch, P.; Droge, W. Effect of glutathione depletion and oral N-acetyl-cysteine treatment on CD4+ and CD8+ cells. FASEB J. 1994, 8, 448-451.

173. Sappey, C.; Legrand-Poels, S.; Best-Belpomme, M.; Favier, A.; Rentier, B.; Piette, J. Stimulation of glutathione peroxidase activity decreases HIV type 1 activation after oxidative stress. AIDS Res. Hum. Retroviruses. 1994, 10, 1451-1461.

174. Bailly, F.; Cotelle, P. Anti-HIV Activities of Natural Antioxidant Caffeic Acid Derivatives: Toward an Antiviral Supplementation Diet. Current Medicinal Chemistry 2005, 12, 1811-1818.

175. Rechner, A. R.; Kroner, C. Anthocyanins and colonic metabolites of dietary polyphenols inhibit platelet function. Thromb. Res. 2005, 116, 327-334.

176. Tanahashi, T. Diversity of Secondary Metabolites from Some Medicinal Plants and Cultivated Lichen Mycobionts. YAKUGAKU ZASSHI 2017, 137, 1443-1482.

177. Shitan, N. Secondary metabolites in plants: transport and self-tolerance mechanisms. Bioscience Biotechnology and Biochemistry 2016.

178. Connor, S. E. O'. Engineering of Secondary Metabolism. Annu. Rev. Genet. 2015, 49, 5.1-5.2.

179. Musilova, L.; Ridl, J.; Polivkova, M.; Macek, T.; Uhlik, O. Effects of Secondary Plant Metabolites on Microbial Populations: Changes in Community Structure and Metabolic Activity in Contaminated Environments. Int. J. Mol. Sci. 2016, 17, 1205.

180. Singh, I. P.; Bodiwala, H. S. Recent advances in anti-HIV natural products. Nat. Prod. Rep. 2010, 27, 1781-1800.

181. Yu, D.; Morris-Natschke, S. L.; Lee, K.-H. New Developments in Natural Products-Based Anti-AIDS Research. Medicinal Research Reviews 2007, 27,108-132.

182. Asres, K.; Seyoum, A.; Veeresham, C.; Bucar, F.; Gibbons, S. Naturally Derived Anti-HIV Agents. Phytother. Res. 2005, 19, 557-581.

183. McCormick, J. L.; Mckee, T. C.; Cardellina, J. H.; Boyd, M. R. HIV inhibitory natural products. 26. Quinoline alkaloids from Euodia roxburghiana. J. Nat. Prod. 1996, 59, 469-471.

184. Duan, H.; Takaishi, Y.; Imakura, Y.; Jia, Y.; Li, D.; Cosentino, L. M. Sesquiterpene alkaloids from Tripterygium hypoglaucum and Tripterygium wilfordii: a new class of potent Anti-HIV agents. J. Nat. Prod. 2000, 63, 357-361.

185. Tan, G. T.; Pezzuto, J. M.; Kinghorn, A. D.; Hughes, S. H. Evaluation of natural products as inhibitors of human immunodeficiency virus type1 (HIV-1) reverse transcriptase. J. Nat. Prod. 1991, 54, 143-154.

186. Ishida, J.; Wang, H.-K.; Oyama, M.; Cosentino, M. L.; Hu, C.-Q.; Lee, K. H. Anti-AIDS agents. 46.1 anti-HIV activity of harman, an anti-HIV principle from Symplocos setchuensis, and its Derivatives. J. Nat. Prod. 2001, 64, 958-960.

187. Loya, S.; Rudi, A.; Kashman, Y.; Hizi, A. Polycitone A, a novel and potent general inhibitor of retroviral reverse transcriptases and cellular DNA polymerases. Biochem. J. 1999, 344, 85-92.

188. Xu, H. X.; Wan, M.; Dong, H.; But, P. P.; Foo, L. Y. Inhibitory activity of flavonoids and tannins against HIV-1 protease. Biol. Pharm. Bull. 2000, 23, 1072-1076.

189. Ravanelli, N.; Santos, K. P.; Motta, L. B.; Lago, J. H. G.; Furlan, C. M. Alkaloids from Croton echinocarpus Baill.: Anti-HIV potential. South African Journal of Botany 2015.

190. White, E. L.; Chao, W. R.; Ross, L. J.; Borhani, D. W.; Hobbs, P. D.; Upender, V. et al. Michellamine alkaloids inhibit protein kinase C. Arch. Biochem. Biophys. 1999, 365, 25-30.

191. Kondo, Y.; Imai, Y.; Hojo, H.; Hashimoto, Y.; Nozoe, S. Selective inhibition of T cell dependent immune responses by bisbenzylisoquinoline alkaloids in vivo. Int. J. Immunopharmacol. 1992, 14, 1181-1186.

192. Meragelman, K. M.; McKee, T. C.; Boyd, M. R. Siamenol, a new carbazole alkaloid from Murraya siamensis. J. Nat. Prod. 2000, 63, 427-428. 
193. Kongkathip, B.; Kongkathip, N.; Sunthitikawinsakul, A.; Napaswat, C.; Yoosook, C. Anti-HIV-1 constituents from Clausena excavata: Part II. Carbazoles and a pyranocoumarin. Phytother Res. 2005, 19, 728-731.

194. Hsieh, P. W.; Chang, F. R.; Lee, K. H.; Hwang, T. L.; Chang, S. M.; Wu, Y. C. A new anti- HIV alkaloid, drymaritin, and a new C-glycoside flavonoid, diandroflavone, from Drymaria diandra. J. Nat. Prod. 2004, 67, $1175-1177$.

195. Wang, J.; Zheng, Y.; Efferth, T.; Wang, R.; Shen, Y.; Hao, X. Indole and carbazole alkaloids from Glycosmis montana with weak anti-HIV and cytotoxic activities. Phytochemistry 2005, 66, 697-701.

196. Jayasuriya, H.; Herath, K. B.; Ondeyka, J. G.; Polishook, J. D.; Bills, G. F.; Dombrowski, A. W.; Springer, M. S.; Siciliano, S.; Malkowitz, L.; Sanchez, M.; Guan, Z.; Tiwari, S.; Stevenson, D. W.; Borris, R. P.; Singh, S. B. Isolation and structure of antagonists of chemokine receptor (CCR5). J. Nat. Prod. 2004, 67, 1036-1038.

197. Cheng, M. J.; Lee, K. H.; Tsai, I. L.; Chen, I. S. Two new sesquiterpenoids and anti-HIV principles from the root bark of Zanthoxylum ailantoides. Bioorg. Med. Chem. 2005, 13, 5915-5920.

198. Stadler, R.; Kutchan, T. M.; Zenk, M. H. (S)-norcoclaurine is the central intermediate in benzylisoquinoline alkaloid biosynthesis. Phytochemistry 1989, 28, 1083-1086.

199. Yan, M. H.; Cheng, P.; Jiang, Z. Y.; Ma, Y. B.; Zhang, X. M.; Zhang, F. X.; Yang, L. M.; Zheng, Y. T.; Chen, J. J. Periglaucines A-D, Anti-HBV and HIV-1 alkaloid from Pericampylus glaucus. J. Nat. Prod. 2008, 71, 760-763.

200. Wu, P. L.; Lin, F. W.; Wu, T. S.; Kuoh, C. S.; Lee, K. H.; Lee, S. J. Cytotoxic and anti-HIV principles from the rhizomes of Begonia nantoensis. Chem. Pharm. Bull. 2004, 52, 345-349.

201. Szlavik, L.; Gyuris, A.; Minarovits, J.; Forgo, P.; Molnarand, J.; Hohmann, J. Alkaloids from Leucojum vernum and antiretroviral activity of amaryllidaceae alkaloids. Planta Med. 2004, 70, 871-873.

202. Otshudi, A. L.; Apers, S.; Pieters, L.; Claeys, M.; Pannecouque, C.; Clercq, E. D.; Zeebroeck, A. V.; Lauwers, S.; Frederich, M.; Foriers, A. Biologically active bisbenzylisoquinoline alkaloids from the root bark of Epinetrum villosum. J. Ethnopharmacol. 2005, 31, 89-94.

203. Chang, Y. C.; Hsieh, P. W.; Chang, F. R.; Wu, R. R.; Liaw, C. C.; Lee, K. H.; Wu, Y. C. Two new protopines argemexicaines $\mathrm{A}$ and $\mathrm{B}$ and the anti-HIV alkaloid 6-acetonyldihydrochelerythrine from formosan Argemone mexicana. Planta Med. 2003, 69, 148-152.

204. Hua, H. M.; Peng, J.; Dunbar, D. C.; Schinazi, R. F.; Andrews, A. G. de C.; Cuevas, C.; Garcia-Fernandez, L. F.; Kellyf, M.; Hamanna, M. T. Batzelladine alkaloids from the caribbean sponge Monanchora unguifera and the significant activities against HIV-1 and AIDS opportunistic infectious pathogens. Tetrahedron 2007, 63, 11179-11188.

205. Peng, J.; Hu, J. F.; Kazi, A. B. Manadomanzamines A and B: a novel alkaloid ring system with potent activity against mycobacteria and HIV-1. J. Am. Chem. Soc. 2003, 125, 13382-13386.

206. Zhang, C. F.; Nakamura, N.; Tewtrakul, S. Sesquiterpenes and alkaloids from Lindera chunii and their inhibitoryactivities against HIV-1 integrase. Chem. Pharm. Bull. 2002, 50, 1195-1200.

207. Ma, C. M.; Nakamura, N.; Hattori, M. Inhibitory effects on HIV1 protease of tri-p-coumaroylspermidine from Artemisia caruifolia and related amides. Chem. Pharm. Bull. 2001, 49, 915-917.

208. Kiyama, R. Estrogenic terpenes and terpenoids: pathways, functions and applications. European Journal of Pharmacology 2017.

209. Kuo, R. Y.; Qian, K.; Susan, L., Natschke, M.; Lee, K. H. Plant-derived triterpenoids and analogues as antitumor and anti-HIV agents. Nat. Prod. Rep. 2009, 26, 1321-1344.

210. Min, B. S.; Jung, H. J.; Lee, J. S.; Kim, Y. H.; Bok, S. H.; Ma, C. M. Inhibitory effect of triterpenes from Crataegus pinatifida on HIV-I protease. Planta Med. 1999, 65, 374-375.

211. Yao-Haur, K.; Li-Ming, Y. K. Antitumour and anti-AIDS triterpenes from Celastrus hindsii. Phytochemistry $1997,44,1275-1281$.

212. El-Mekkawy, S.; Meselhy, M. R.; Nakamura, N.; Hattori, M.; Kawahata, T.; Otake, T. Anti-HIV-1 phorbol esters from the seeds of Croton tiglium. Phytochemistry 2000, 53, 457-464.

213. Rukachaisirikul, V.; Pailee, P.; Hiranrat, A.; Tuchinda, P.; Yoosook, C.; Kasisit, J. Anti-HIV-1 protostane triterpenes and digeranylbenzophenone from trunk bark and stems of Garcinia speciosa. Planta Med. 2003, 69, 1141-1146.

214. Xu, H.-X.; Zeng, F.-Q.; Wan, M.; Sim, K.-Y. Anti-HIV triterpene acids from Geum japonicum. J. Nat. Prod. 1996, 59, 643-645.

215. Chen, D.-F.; Zhang, S.-X.; Wang, H.-K.; Zhang, S.-Y.; Sun, Q.-Z.; Cosentino, L. M. Novel anti-HIV lancilactone $C$ and related triterpenes from Kadsura lancilimba. J. Nat. Prod. 1999, 62, 94-97.

216. Nakamura N. Inhibitory effects of some traditional medicines on proliferation of HIV-1 and its protease. Yakugaku Zasshi. 2004, 124, 519-529. 
217. Li, H.-Y.; Sun, N.-J.; Kashiwada, Y.; Sun, L.; Snider, J. V.; Cosentino, L. M. Anti-AIDS agents, 9. Suberosol, a new C-31 lanostane-type triterpene and Anti-HIV principle from Polyalthia suberosa. J. Nat. Prod. 1993, 56, 1130-1133.

218. Barbosa, J. P.; Pereira, R. C.; Abrantes, J. L.; DosSantos, C. C. C.; Rebello, M. A.; Frugulhetti, I. C. P. P. In vitro antiviral diterpenes from the Brazil brown alga Dictyota pfaffii. Planta Med. 2004, 70, 856-860.

219. Cirne-Santos, C. C.; Teixeira, V. L.; Castello-Branco, L. R.; Frugulheti, I. C. P. P.; Bou Habid, D. C. Inhibition of HIV-1 replication in human primary cells by a dolabellane diterpene isolated from the marine algae Dictyota pfaffii. Planta Med. 2006, 72, 295-299.

220. Zhang, H. J.; Huang, N. V.; Cuong, N. M.; Soejarto, D. D.; Pezzuto, J. M.; Fong, H. H. S. Sesquiterpenes and butenolides, natural anti-HIV constituents from Litsea verticillata. Planta Med., 2005, 71, 452-457.

221. Pereira, H. S.; Leao-Ferreira, L. R.; Moussatché, N.; Teieira, V. L.; Cavalcanti, D. N. da; Costa, L. J. Effects of diterpenes isolated from the Brazilian marine alga Dictyota menstrualis on HIV-1 reverse transcriptase. Planta Med. 2005, 71, 1019-1024.

222. Sunthitikawinsakul, A.; Kongkathip, N.; Kongkathip, B. Anti-HIV-1 limonoid: first isolation from Clausena excavata. Phytother Res. 2003, 17, 1101-1103.

223. Ito, M.; Sato, A.; Hirabayashi, K. Mechanism of inhibitory effect of glycyrrhizin on replication of human immunodeficiency virus (HIV). Antiviral Res. 1988, 10, 289-298.

224. Bocklandt, S.; Blumberg, P. M.; Hamer, D. H. Activation of latent HIV-1 expression by the potent anti-tumor promoter 12-deoxyphorbol 13-phenylacetate. Antiviral Res. 2003, 59, 89-98.

225. Pettit, G. R.; Ducki, S.; Tan, R. Isolation and structure of pedilstatin from a republic of Maldives Pedilanthus sp. J. Nat. Prod. 2002, 65, 1262-1265.

226. Huang, S. Z.; Zhang, X.; Ma, Q. Y.; Zheng, Y. T.; Xu, F. Q.; Peng, H.; Dai, H. F.; Zhou, J.; Zhao, Y. X. Terpenoids and their anti-HIV activities from Excoecaria acerifolia. Fitoterapia 2013, 91, 224-230.

227. Anjaneyulu, A. S. R.; Rao, V. L.; Sreedhar, K. Agallochins, New isopimarane diterpenoids from Excoecaria agallocha. J. Nat. Prod. Res. 2003, 17, 27-32.

228. Konishi, T.; Azuma, M.; Itoga, R.; Kiyosawa, S.; Fujiwara, Y.; Shimada, Y. Three new labdane-type diterpenes from wood, Excoecaria agallocha. Chem. Pharm. Bull. 1996, 44, 229-231.

229. Gangloff, A. R.; Judge, T. M; Helquist, P. Light-induced, iodine-catalyzed aerobic oxidation of unsaturated tertiary amines. J. Org. Chem. 1990, 55, 3679-3682.

230. Sun, I-C.; Kashiwada, Y.; Morris-Natschke, S. L.; Lee, K.-H. Plant-derived Terpenoids and Analogues as Anti-HIV Agents. Current Topics in Medicinal Chemistry 2003, 3, 155-169.

231. Gustafson, K. R.; Cardellina, J. H.; McMahon, J. B.; Gulakowski, R. J.; Ishitoya, J.; Szallasi, Z.; Lewin, N. E.; Blumberg, P. M.; Weislow, O. S.; Beutler, J. A.; Buckheit Jr, R. W.; Cragg, G. M.; Cox, P. A.; Bader, J. P.; Boyd, M. R. A Nonpromoting Phorbol from the Samoan Medicinal Plant Homalanthus nutans Inhibits Cell Killing by HIV1. J. Med. Chem. 1992, 35, 1978-1986.

232. Osorio, A. A.; Munoz, A.; Romero, D. T.; Bedoya, L. M.; Perestelo, N. R.; Jimenez, I. A.; Alcami, J.; Bazzocchi, I. L. Olean-18-ene triterpenoids from Celastraceae species inhibit HIV replication targeting $\mathrm{NF-Kb}$ and Sp1 dependent transcription. European Journal of Medicinal Chemistry 2012, 52, 295-303.

233. Song, W.; Si, L.; Ji, S.; Wang, H.; Fang, X-M.; Yu, L.-Y.; Li, R.-Y.; Liang, L.-N.; Zhou, D.; Ye, M. Uralsaponins M-Y, Antiviral Triterpenoid Saponins from the Roots of Glycyrrhiza uralensis. J. Nat. Prod. 2014.

234. Vidal, V.; Potterat, O.; Louvel, S.; Hamy, F.; Mojarrab, M.; Sanglier, J.-J.; Klimkait, T.; Hamburger, M. Library-Based Discovery and Characterization of Daphnane Diterpenes as Potent and Selective HIV Inhibitors in Daphne gnidium. J. Nat. Prod. 2012, 75, 414-419.

235. Tian, Y.; Xu, W.; Zhu, C.; Lin, S.; Li, Y.; Xiong, L.; Wang, S.; Wang, L.; Yang, Y.; Guo, Y.; Sun, H.; Wang, X.; Shi, J. Lathyrane Diterpenoids from the Roots of Euphorbia micractina and Their Biological Activities. J. Nat. Prod. 2011, 74, 1221-1229.

236. Win, N. N.; Ito, T.; Matsui, T.; Aimaiti, S.; Kodama, T.; Ngwe, H.; Okamoto, Y.; Tanaka, M.; Asakawa, Y.; Abe, I.; Morita, H. Isopimarane diterpenoids from Kaempferia pulchra rhizomes collected in Myanmar and their Vpr inhibitory activity. Bioorg. E Medicinal Chem. Lett. 2016, 26, 1789-1793.

237. Win, N. N.; Ngwe, H.; Abe, I.; Morita, H. Naturally occurring Vpr inhibitors from medicinal plants of Myanmar. J. Nat. Med. 2017.

238. Xiao, W.-L.; Li, R.-T.; Li, S.-H.; Li, X.-L.; Sun, H.-D.; Zheng, Y. T.; Wang, R. R.; Lu, Y.; Wang, C.; Zheng, Q. T. Lancifodilactone F: A Novel Nortriterpenoid Possessing a Unique Skeleton from Schisandra lancifolia and Its Anti-HIV Activity. Organic Letters 2005, 7, 1263-1266.

239. Yan, M.; Lu, Y.; Chen, C. H.; Zhao, Y.; Lee, K. H.; Chen, D. F. Stelleralides D-J and Anti-HIV Daphnane Diterpenes from Stellera chamaejasme. J. Nat. Prod. 2015.

240. Takeda, K.; Horibe, I.; Minato, H. Components of the root of Lindera strychnifolia vill. Part XIV. Sesquiterpene lactones from the root of Lindera strychnifolia vill. J. Chem. Soc. C 1968, 569-572. 
241. Zhang, X.; Huang, S. Z.; Gu, W. G.; Yang, L. M.; Chen, H.; Zheng, C. B.; Zhao, Y. X.; Wan, D. C. C.; Zheng, Y. T. Wikstroelide $M$ potently inhibits HIV replication by targeting reverse transcriptase and integrase nuclear translocation. Chinese Journal of Natural Medicines 2014, 12, 0186-0193.

242. Wu, Y. C.; Hung, Y. C.; Chang, F. R.; Cosentino, M.; Wang, H. K.; Lee, K. H. Identification of ent-16 $\beta, 17$ dihydroxykauran-19-oic acid as an anti-HIV principle and isolation of the new diterpenoids annosquamosins A and B from Annona squamosa. J. Nat. Prod. 1996, 59, 635-637.

243. Singh, I. P.; Bharate, S. B.; Bhutani, K. K. Anti-HIV natural products. Current Science 2005, 89, $269-290$.

244. Sun, H. D.; Qiu, S. X.; Lin, L. Z.; Wang, Z. Y.; Lin, Z. W.; Pengsuparp, T.; Pezzuto, J. M.; Fong, H. H.; Cordell, G. A.; Farnsworth, N. R. Nigranoic acid, a triterpenoid from Schisandra sphaerandra that inhibits HIV-1 reverse transcriptase. J. Nat. Prod. 1996, 59, 525-527.

245. Okano, M.; Fukamiya, N.; Tagahara, K.; Cosentino, M.; Lee, T. T-Y.; Morris-Natschke, S.; Lee, K.-H. Anti-AIDS agents 25. Anti-HIV activity of quassinoids. Bioorg. Med. Chem. Lett. 1996, 6, 701-706.

246. Wei, Y.; Ma, C. M.; Hattori, M. Anti-HIV protease triterpenoids from the acid hydrolysate of Panax ginseng. Phytochem. Lett. 2009, 2, 63-66.

247. Reutrakul, V.; Anantachoke, N.; Pohmakotr, M.; Jaipetch, T.; Yoosook, C.; Kasisit, J.; Napaswa, C.; Panthong, A.; Santisuk, T.; Prabpai, S.; Kongsaeree, P.; Tuchinda, P. Anti-HIV-1 and anti-inflammatory lupanes from the leaves, twigs and resin of Garcinia hanburyi. Planta Med. 2010, 76, 368-371.

248. Daoubi, M.; Marquez, N.; Mazoir, N.; Benharref, A.; Hernandez-Galan, R.; Munoz, E.; Collado, I. E. Isolation of new phenylacetylingol derivatives that reactivate HIV-1 latency and a novel spirotriterpenoid from Euphorbia officinarum latex. Bioorg. Med. Chem. 2007, 15, 4577-4584.

249. Tian, R. R.; Chen, J. C.; Zhang, G. H.; Qiu, M. H.; Wang, Y. H.; Du, L.; Shen, X.; Liu, N. F.; Zheng, Y. T. Cucurbitane triterpenoids from Hemsleya penxianensis. Chin. J. Nat. Med. 2008, 6, 214-218.

250. Bodiwala, H. S.; Sabde, S.; Mitra, D.; Bhutani, K. K.; Singh, I. P. Anti-HIV diterpenes from Coleus forskohlii. Nat. Prod. Commun. 2009, 4, 1173-1175.

251. Chen, I. H.; Du, Y.-C.; Lu, M. C.; Lin, A. S.; Hsieh, P. W.; Wu, C. C.; Chen, S. L.; Yen, H. F.; Chang, F. R.; Wu, Y. C. Lupane-type triterpenoids from Microtropis fokienensis and Perrottetia arisanensis and the apoptotic effect of 28-hydroxy-3-oxo-lup-20(29)-en-30-al. J. Nat. Prod. 2008, 71, 1352-1357.

252. Kashiwada, Y.; Sekiya, M.; Yamazaki, K.; Ikeshiro, Y.; Fujioka, T.; Yamagishi, T.; Kitagawa, S.; Takaishi, Y. Triterpenoids from the floral spikes of Betula platyphylla var. japonica and their reversing activity against multidrug-resistant cancer cells. J. Nat. Prod. 2007, 70, 623-627.

253. Ramachandran, C.; Nair, P. K.; Alamo, A.; Cochrane, C. B.; Escalon, E.; Melnick, S. J. Anticancer effects of amooranin in human colon carcinoma cell line in vitro and in nude mice xenografts. Int. J. Cancer. 2006, 119, 2443-2454.

254. Tian, J.-K.; Xu, L. Z.; Zou, Z. M.; Yang, S. L. Three Novel Triterpenoid Saponins from Lysimachia capillipes and Their Cytotoxic Activities. Chem. Pharm. Bull. 2006, 54, 567-569.

255. Yue, Q. X.; Cao, Z. W.; Guan, S. H.; Liu, X. H.; Tao, L.; Wu, W. Y.; Li, Y. X.; Yang, P. Y.; Liu, X.; Guo, D. A. Proteomics characterization of the cytotoxicity mechanism of ganodeic acid D and computer-automated estimation of the possible drug target network. Mol. Cell Proteomics. 2008, 7, 949-961.

256. Chang, U. M.; Li, C. H.; Lin, L. I.; Huang, C. P.; Kan, L. S.; Lin, S. B. Ganoderiol F, a ganoderma triterpene, induces senescence in hepatoma HepG2 cells. Life Sci. 2006, 79, 1129-1139.

257. Sun, P.; Liu, B. S.; Yi, Y. H.; Li, L.; Gui, M.; Tang, H. F.; Zhang, D. Z.; Zhang, S. L. A new cytotoxic lansotane-type triterpene glycoside from the sea cucumber Holothuria impatiens. Chem. Biodiversity. 2007, 4, 450-457.

258. Feng, T.; Wang, R. R.; Cai, X. H.; Zheng, Y. T.; Luo, X. D. Anti-human immunodeficiency virus-1 constituents of the bark of Poncirus trifoliate. Chem. Pharm. Bull. (Tokyo) 2010, 58, 971-975.

259. Yang, L.; Wu, S.; Zhang, Q.; Liuand, F.; Wu, P. 23, 24-Dihyrocucurbitacin B induces G2/M cell-cycle arrest and mitochondria dependent apoptosis in human breast cancer cells (Bcap37). Cancer Lett. 2007, 256, 267-278.

260. Fang, L.; Ito, A.; Chai, H. B; Mi, Q.; Jones, W. P.; Madulid, D. R.; Oliveros, M. B.; Gao, Q.; Orjala, J.; Farnsworth, N. R.; Soejarto, D. D.; Cordell, G. A.; Swanson, S. M.; Pezzuto, J. M.; Kinghorn, A. D. Cytotoxic constituents from the stem bark of Dichapetalum gelonioides collected in the Philippines. J. Nat. Prod. 2006, 69, 332-337.

261. Tuchinda, P.; Kornsakulkarn, J.; Pohmakotr, M.; Kongsaeree, P.; Prabpai, S.; Yoosook, C.; Kasisit, J.; Napaswad, C.; Sophasan, S.; Reutrakul, V. Dichapetalin-type triterpenoids and lignans from the aerial parts of Phyllanthus acutissima. J. Nat. Prod. 2008, 71, 655-663.

262. Lee, J. H.; Koo, T. H.; Yoon, H.; Jung, H. S.; Jin, H. Z.; Lee, K.; Hong, Y. S.; Lee, J. J. Inhibition of NF-kappa B activation through targeting I kappa B kinase by celastrol, a quinine methide triterpenoid. Biochem. Pharmacol. 2006, 72, 1311-1321. 
263. Zhang, H.; Wang, X.; Chen, F.; Androulakis, X. M.; Wargovich, M. J. Anticancer activity of limonoid from Khaya senegalensis. Phytother Res. 2007, 21, 731-734.

264. Awah, F. M.; Uzoegwu, P. N.; Ifeonu, P. In vitro anti-HIV and immunomodulatory potentials of Azadirachta indica (Meliaceae) leaf extract. African Journal of Pharmacy and Pharmacology 2011, 5, 1353-1359.

265. Uddin, S. J.; Nahar, L.; Shilpi, J. A.; Shoeb, M.; Borkowski, T.; Gibbons, S.; Middleton, M.; Byres, M.; Sarker, S. D. Gedunin, a limonoid from Xylocarpus granatuum, inhibits the growth of CaCo-2 colon cancer cell line in vitro. Phytother Res. 2007, 21, 757-761.

266. Seida, A. A.; Kinghorn, A. D.; Cordell, G. A.; Farnsworth, N. R. Potential anticancer agents. IX. Isolation of a new simaroubolide, 6alpha-tigloyloxychaparrinone, from Ailanthus integrifolia ssp. Calyciina (Simaroubaceae). Lloydia 1978, 41, 584-587.

267. Orhan, D. D.; Ozcelik, B.; Ozgen, S.; Ergun, F. Antibacterial, antifungal, and antiviral activities of some flavonoids. Microbiol. Res. 2010, 165, 496-504.

268. Kim, H. J.; Woo, E.-R.; Shin, C.-G.; Park, H. Anewflavonol glycoside gallate ester from Acer okamotoanum and its inhibitory activity againsthuman immunodeficiency virus-1 (HIV-1) integrase. J. Nat. Prod. 1998, 61, 145-148.

269. Wang, Q.; Ding, Z.-H.; Liu, J.-K.; Zheng, Y.-T. Xanthohumol, a novel anti-HIV-1 agent purified from Hops Humulus lupulus. Antiviral Res. 2004, 64, 189-194.

270. Meragelman, K. M.; Mckee, T. C.; Boyd, M. R. Anti-HIV prenylated flavonoids from Monotes africanus 1. J. Nat. Prod. 2001, 64, 546-548.

271. Hu, K.; Kobayashi, H.; Dong, A.; Iwasaki, S.; Yao, X. Antifungal, antimitotic and anti-HIV-1 agents from the roots of Wikstroemia indica. Planta Med. 2000, 66, 564-567.

272. Ohtake, N.; Nakai, Y.; Yamamoto, M.; Sakakibara, I.; Takeda, S.; Amagaya, S. Separation and isolation methods for analysis of the active principles of Sho-saiko-to (SST) oriental medicine. J. Chromatogr. B 2004, 812, 135-148.

273. Lin, Y.-M.; Anderson, H.; Flavin, M. T.; Pai, Y.-H. S.; Mata-Greenwood, E.; Pengsuparp, T. In vitro anti-HIV activity of biflavonoids isolated from Rhus succedanea and Garcinia multiflora. J. Nat. Prod. 1997, 60, 884-888.

274. Wu, J. H.; Wang, X. H.; Yi, Y. H.; Lee, K. H. Anti-AIDS agents 54. A potent anti-HIV chalcone and flavonoids from genus Desmos. Bioorg. Med. Chem. Lett. 2003, 13, 1813-1815.

275. Cheenpracha, S.; Karalai, C.; Ponglimanont, C.; Subhadhirasakul, S.; Tewtrakul, S. Anti-HIV-1 protease activity of compounds from Boesenbergia pandurata. Bioorg. Med. Chem. 2006, 14, 1710-1714.

276. Critchfield, J. W.; Coligan, J. E.; Folks, T. M.; Butera, S. T. Casein kinase II is a selective target of HIV-1 transcriptional inhibitors. Proc. Natl. Acad. Sci. USA 1997, 94, 6110-6115.

277. Harada, S.; Haneda, E.; Maekawa, T.; Morikawa, Y.; Funayama, S.; Nagata, N. Casein kinase II (CK-II)-mediated stimulation of HIV-1 reverse transcriptase activity and characterization of selective inhibitors in vitro. Biol. Pharm. Bull. 1999, 22, 1122-1126.

278. Rowley, D. C.; Hansen, M. S. T.; Rhodes, D.; Sotriffer, C. A.; Ni, H.; McCammon, J. A. Thalassiolins A-C: new marine-derived inhibitors of HIV cDNA integrase. Bioorg. Med. Chem. 2002, 10, 3619-3625.

279. Alves, C. N.; Pinheiro, J. C.; Camargo, A. J. de; Souza, A. J.; Carvalho, R. B. da; Silva, A. B. F. A quantum chemical and statistical study of flavonoid compounds with anti-HIV activity. J. Mol. Struct. (Theochem.) 1999, 491, 123-131.

280. Alves, C. N.; Pinheiro, J. C.; Camargo, A. J.; Ferreira, M. M. C.; Romero, R. A. F. da; Silva, A. B. F. A multiple linear regression and partial least squares study of flavonoid compounds with anti-HIV activity. J. Mol. Struct. (Theochem) 2001, 541, 81-88.

281. Min, B. S.; Lee, H. K.; Lee, S. M. Anti-human immunodeficiency virus-type 1 activity of constituents from Juglans mandshurica. Arch. Pharm. Res. 2002, 25, 441-445.

282. Lee-Huang, S.; Zhang, L.; Huang, P. L. Anti-HIV activity of olive leaf extract (OLE) and modulation of host cell gene expression by HIV-1 infection and OLE treatment. Biochem. Biophys. Res. Commun. 2003, 307, 1029-1037.

283. Amzazi, S.; Ghoulami, S.; Bakri, Y. Human immunodeficiency virus type 1 inhibitory activity of Mentha longifolia. Therapie 2003, 58, 531-534.

284. Lo, W. L.; Wu, C. C.; Chang, F. R. Antiplatelet and anti-HIV constituents from Euchresta formosana. Nat. Prod. Res. 2003, 17, 91-97.

285. Mahmood, N.; Pizza, C.; Aquino, R. Inhibition of HIV infection by flavonoids. Antiviral Res. 1993, 22, 189199.

286. Hussein, G.; Miyashiro, H.; Nakamura, N. Inhibitory effects of Sudanese plant extracts on HIV-1 replication and HIV-1 protease. Phytother Res. 1999, 13, 31-36.

287. Mahmood, N.; Piacente, S.; Pizza, C. The anti-HIV activity and mechanisms of action of pure compounds isolated from Rosa damascena. Biochem. Biophys. Res. Commun. 1996, 229, 73-79. 
288. Boskabady, M. H.; Shafei, M. N.; Saberi, Z.; Amini, S. Pharmacological Effects of Rosa Damascena. Iranian Journal of Basic Medical Sciences 2011, 14, 295-307.

289. Dharmaratne, H. R. W.; Tan, G. T.; Marasinghe, G. P. K.; Pezzuto, J. M. Inhibition of HIV-1 reverse transcriptase and HIV-1 replication by Calophyllum coumarins and Xanthones. Planta Med. 2002, 68, 86-87.

290. Vlietinck, A. J.; De Bruyne, T.; Apers, S.; Pieters, L. A. Plant derived leading compounds for chemotherapy of human immunodeficiency virus (HIV) infection. Planta Med. 1998, 64, 97-109.

291. Lee, T. T.-Y.; Kashiwada, Y.; Huang, L.; Snider, J.; Cosentino, M.; Lee, K.-H. Suksdorfin: an anti-HIV principle from Lomatium suksdorfii, its structure-activity correlation with related coumarins, and synergistic effects with anti-AIDS nucleosides. Bioorg. Med. Chem. 1994, 2, 1051-1056.

292. Yu, D.; Suzuki, M.; Xie, L.; Morris-Natschke, S. L.; Lee, K.-H. Recent progress in the development of coumarin derivatives as potent anti-HIV agents. Med. Res. Rev. 2003, 23, 322-345.

293. Zhou, P.; Takaishi, Y.; Duan, H.; Chen, B.; Honda, G.; Itoh, M. Coumarins and bicoumarin from Ferula sumbul: anti-HIV activity and inhibition of cytokine release. Phytochemistry 2000, 53, 689-697.

294. Shikishima, Y.; Takaishi, Y.; Honda, G.; Ito, M.; Takfda, Y.; Kodzhimatov, O. K.; Ashurmetov, O.; Lee, K. H. Chemical constituents of Prangos tschiniganica; structure elucidation and absolute configuration of coumarin and furanocoumarin derivatives with anti-HIV activity. Chem. Pharm. Bull. (Tokyo) 2001, 49, 877-880.

295. Marquez, N.; Sancho, R.; Bedoya, L. M.; Alcami, J.; Lopez-Perez, J. L.; San, F. A. Mesuol, a natural occurring 4-phenylcoumarin, inhibits HIV-1 replication by targeting the NF-kB pathway. Antiviral Res. 2005, 66, 137-145.

296. Xu, Z. Q.; Kern, E. R.; Westbrook, L.; Allen, L. B.; Buckheit, R. W.; Jr.; Tseng, C. K.; Jenta, T.; Flavin, M. T. Plant-derived and semi-synthetic calanolide compounds with in vitro activity against both human immunodeficiency virus type 1 and human cytomegalovirus. Antivir. Chem. Chemother. 2000, 11, $23-29$.

297. Mishra, B. B.; Singh, D. D.; Kishore, N.; Tiwari, V. K.; Tripathi, V. Antifungal constituents isolated from the seeds of Aegle marmelos. Phytochemistry 2010, 71, 230-234.

298. Maity, P.; Hansda, D.; Bandyopadhyay, U.; Mishra, D. K. Biological activities of crude extracts and chemical constituents of Bael, Aegle marmelous (L.) Corr. Indian Journal of Experimental Biology 2009, 47, 849-861.

299. O'Keefe, B. R. Biologically active proteins from natural product extracts. J. Nat. Prod. 2001, 64, 1373-1381.

300. Lee-Huang, S.; Huang, P. L.; Bourinbaiar, A. S.; Chen, H. C.; Kung, H. F. Inhibition of the integrase of human immunodeficiency virus (HIV) type-1 by anti-HIV plant proteins MAP30 and GAP31. Proc. Natl. Acad. Sci. USA 1995, 92, 8818-8822.

301. McGrath, M. S.; Hwang, K. M.; Caldwell, S. E.; Gaston, I.; Luk, K. C.; Wu, P. GLQ223-an inhibitor of human immunodeficiency virus replication in acutely and chronically infected-cells of lymphocyte and mononuclear phagocyte lineage. Proc. Natl. Acad. Sci. USA 1989, 86, $2844-2848$.

302. Kaur, I.; Puri, M.; Ahmed, Z.; Blanchet, F. P.; Mangeat, B.; Piguet, V. Inhibition of HIV-1 Replication by Balsamin, a Ribosome Inactivating Protein of Momordica balsamina. PLOS ONE 2013, 8, e73780

303. Kawahata, T.; Otake, T.; Mori, H. A novel substance purified from Perilla frutescens Britton inhibits an early stage of HIV-1 replication without blocking viral adsorption. Antivir. Chem. Chemother. 2002, 13, 283-288.

304. Irvin, J. D.; Uckun, F. M. Pokeweed antiviral protein: ribosome inactivation and therapeutic applications. Pharmacol. Ther. 1992, 55, 279-302.

305. Wang, H. X.; Ng, T. B. Ascalin, a new anti-fungal peptide with human immunodeficiency virus type 1 reverse transcriptase-inhibiting activity from shallot bulbs. Peptides 2002, 23, 1025-1029.

306. Wang, H.; Ye, X. Y.; Ng, T. B. Purification of chrysancorin, a novel antifungal protein with mitogenic activity from garland chrysanthemum seeds. Biol. Chem. 2001, 382, 947-951.

307. Wang, H.; Ng, T. B. Ginkbilobin, a novel antifungal protein from Ginkgo biloba seeds with sequence similarity to embryo-abundant protein. Biochem. Biophys. Res. Commun. 2002, 279, 407-411.

308. Ye, X. Y.; Ng, T. B. Hypogin, a novel antifungal peptide from peanuts with sequence similarity to peanut allergen. J. Pept. Res. 2001, 57, 330-336.

309. Lam, S. K.; Ng, T. B. First simultaneous isolation of a ribosome inactivating protein and an antifungal protein from a mushroom (Lyophyllum shimeji) together with evidence for synergism of their antifungal effects. Arch. Biochem. Biophys. 2001, 393, 271-280.

310. Wang, H. X.; Ng, T. B. Quinqueginsin, a novel protein with anti-human immunodeficiency virus, antifungal, ribonuclease and cell-free translation-inhibitory activities from American ginseng roots. Biochem. Biophys. Res. Commun. 2000, 269, 203-208.

311. Wang, H.; $\mathrm{Ng}$, T. B. Isolation and characterization of velutin, a novel low-molecular-weight ribosome-inactivating protein from winter mushroom (Flammulina velutipes) fruiting bodies. Life Sci. 2001, $68,2151-2158$. 
312. Wang, H. X.; Ng, T. B. Purification of a novel low-molecular mass laccase with HIV-1 reverse transcriptase inhibitory activity from the mushroom Tricholoma giganteum. Biochem. Biophys. Res. Commun. 2004, 315, 450-454.

313. Chu, K. T.; Ng, T. B. Mollisin, an antifungal protein from the chestnut Castanea mollissima. Planta Med. 2003, 69, 809-813.

314. Bokesch, H. R.; Charan, R. D.; Meragelman, K. M. Isolation and characterization of anti-HIV peptides from Dorstenia contrajerva and Treculia obovoidea. FEBS Lett. 2004, 567, 287- 290.

315. Wong, J. H.; Ng, T. B. Purification of a trypsin-stable lectin with antiproliferative and HIV-1 reverse transcriptase inhibitory activity. Biochem. Biophys. Res. Commun. 2003, 301, 545-550.

316. Ye, X. Y.; Ng, T. B. Delandin, a chitinase-like protein with antifungal, HIV-1 reverse transcriptase inhibitory and mitogenic activities from the rice bean Delandia umbellata. Protein Expr. Purif. 2002, 24, 524-529.

317. Ye, X. Y.; Ng, T. B. Purification of angularin, a novel antifungal peptide from adzuki beans. J. Pept. Sci. 2002, 8, 101-106.

318. Chu, K. T.; Ng, T. B. Isolation of a large thaumatin-like antifungal protein from seeds of the Kweilin chestnut Castanopsis chinensis. Biochem. Biophys. Res. Commun. 2003, 301, 364-370.

319. Ye, X. Y.; Wang, H. X.; Ng, T. B. Structurally dissimilar proteins with antiviral and antifungal potency from cowpea (Vigna unguiculata) seeds. Life Sci. 2000, 67, 3199-3207.

320. Ye, X. Y.; Ng, T. B.; Tsang, P. W.; Wang, J. Isolation of a homodimeric lectin with antifungal and antiviral activities from red kidney bean (Phaseolus vulgaris) seeds. J. Protein Chem. 2001, 20, 367-375.

321. Wang, H.; Ng, T. B. Isolation of an antifungal thaumatin-like protein from kiwi fruits. Phytochemistry 2002, 61, 1-6.

322. Ngai, P. H.; Ng, T. B. Lentin, a novel and potent antifungal protein from shitake mushroom with inhibitory effects on activity of human immunodeficiency virus-1 reverse transcriptase and proliferation of leukemia cells. Life Sci. 2003, 73, 3363-3374.

323. Lam, Y. W.; Ng, T. B. A monomeric mannose-binding lectin from inner shoots of the edible chive (Allium tuberosum). J. Protein Chem. 2001, 20, 361-366.

324. Ye, X. Y.; Ng, T. B. A new antifungal protein and a chitinase with prominent macrophage-stimulating activity from seeds of Phaseolus vulgaris cv. pinto. Biochem. Biophys. Res. Commun. 2002, 290, 813-819.

325. Wang, H.; $\mathrm{Ng}$, T. B. Isolation of lilin, a novel arginine- and glutamate-rich protein with potent antifungal and mitogenic activities from lily bulbs. Life Sci. 2002, 70, 1075-1084.

326. Ye, X. Y.; Ng, T. B. A new peptidic protease inhibitor from Vicia faba seeds exhibit antifungal, HIV-1 reverse transcriptase inhibiting and mitogenic activities. J. Pept. Sci. 2002, 8, 656-662.

327. Ye, X. Y.; Ng TB. Isolation of unguilin, a cyclophilin-like protein with anti-mitogenic, antiviral, and antifungal activities, from black-eyed pea. J. Protein Chem. 2001, 20, 353-359.

328. Lam, S. K.; Ng, T. B. A xylanase from roots of sanchi ginseng (Panax notoginseng) with inhibitory effects on human immunodeficiency virus-1 reverse transcriptase. Life Sci. 2002, 70, 3049-3058.

329. Ye, X. Y.; $\mathrm{Ng}, \mathrm{T}$. B. Isolation of vulgin, a new antifungal polypeptide with mitogenic activity from the pinto bean. J. Pept. Sci. 2003, 9, 114-119.

330. Ye, X. Y.; $\mathrm{Ng}$, T. B. Isolation of a new cyclophilin-like protein from chickpeas with mitogenic, antifungal and anti-HIV-1 reverse transcriptase activities. Life Sci. 2002, 70, 1129-1138.

331. Wang, H.; Ng, T. B. Novel antifungal peptides from Ceylon spinach seeds. Biochem. Biophys. Res. Commun. 2001, 288, 765-770.

332. Ye, X. Y.; Ng, T. B. A new antifungal peptide from rice beans. J. Pept. Res. 2002, 60, 81-87.

333. DeBruyne, T.; Pieters, L.; Deelstra, H.; Vlietinck, A. Condensed vegetable tannins: biodiversity in structure and biological activities. Biochem. Syst. Ecol. 1999, 27, 445-459.

334. Khanbabaee, K. van; Ree, T. Tannins: classification and definition. Nat. Prod. Rep. 2001, 18, 641-649.

335. Notka, F.; Meier, G.; Wagner, R. Concerted inhibitory activities of Phyllanthus amarus on HIV replication in vitro and ex vivo. Antiviral Res. 2004, 64, 93-102.

336. Amouroux, P.; Jean, D.; Lamaison, J. L. Antiviral activity in vitro of Cupressus sempervirens on two human retroviruses HIV and HTLV. Phytother Res. 1998, 12, 367-368.

337. Liu, S.; Lu, H.; Zhao, Q.; He, Y.; Niu, J.; Debnath, A. K.; et al. Theaflavin derivatives in black tea and catechin derivatives in green tea inhibit HIV-1 entry by targeting gp41. Biochem. Biophys. Acta. 2005, 1723, 270-281.

338. Charlton, J. L. Antiviral activity of lignans. J. Nat. Prod. 1998, 61, 1447-1451.

339. Rimando, A. M.; Pezzuto, J. M.; Farnsworth, N. R.; Santisuk, T.; Reutrakul, V.; Kawanishi, K. New lignans from Anogeissus acuminata with HIV1 reverse transcriptase inhibitory activity. J. Nat. Prod. 1994, 57, 896-904.

340. Lee, S. S.; Lin, M. T.; Liu, C. L.; Lin, Y. Y.; Liu, K. C. S. C. Six Lignans from Phyllanthus myrtifolius. J. Nat. Prod. 1996, 59, 1061-1065. 
341. Chen, D. F.; Zhang, S. X.; Xie, L.; Xie, J. X.; Chen, K.; Kashiwada, Y. Anti-AIDS agents-XXVI. Structure-activity correlations of gomisin-G-related anti-HIV lignans from Kadsura interior and of related synthetic analogues. Bioorg. Med. Chem. 1997, 5, 1715-1723.

342. Kashiwada, Y.; Nishizawa, M.; Yamagishi, T.; Tanaka, T.; Nonaka, G.; Cosentino, L. M.; Lee, K. -H. Anti-AIDS agents 18. Sodium and potassium salts of caffeic acid tetramers from Arnebia euchroma as anti-HIV agents. J. Nat. Prod. 1995, 58, 392-400.

343. Piccinelli, A. L.; Mahmood, N.; Mora, G.; Poveda, L.; De Simone, F.; Rastrelli, L. Anti-HIV activity of dibenzylbutyrolactone-type lignans from Phenax species endemic in Costa Rica. J. Pharm. Pharmacol. 2005, 57, 1109-1115.

344. Chen, M.; Kilgore, N.; Lee, K. H.; Chen, D. F. Rubrisandrins A and B, lignans and related anti-HIV compounds from Schisandra rubriflora. J. Nat. Prod. 2006, 69, 1697-1701.

345. Khan, M. T. H.; Ather, A. Potentials of phenolic molecules of natural origin and their derivatives as anti-HIV agents. Biotechnology Annual Review 2007, 13, 1387-2656.

346. El-Mekkawy, S.; Meselhy, M. R.; Kusumoto, I. T.; Kadota, S.; Hattori, M.; Namba, T. Inhibitory effects of Egyptian folk medicines on human immunodeficiency virus (HIV) reverse transcriptase. Chem. Pharm. Bull. 1995, 43, 641-648.

347. Chien, N. Q.; Hung, N. V.; Santarsiero, B. D.; Mesecar, A. D.; Cuong, N. M.; Soejarto, D. D.; Pezzuto, J. M.; Fong, H. H. S.; Tan, G. T. New 3-O-Acyl Betulinic Acids from Strychnos vanprukii Craib. J. Nat. Prod. 2004, 67, 994-998.

348. Connell, B. J.; Chang, S.-Y.; Prakash, E.; Yousfi, R.; Mohan, V.; Posch, W.; Wilflingseder, D.; Moog, C.; Kodama, E. N.; Clayette, P.; Lortat-Jacob, H. A Cinnamon-Derived Procyanidin Compound Displays Anti-HIV-1 Activity by Blocking Heparan Sulfate- and Co-Receptor- Binding Sites on gp120 and Reverses T Cell Exhaustion via Impeding Tim-3 and PD-1 Upregulation. PLOS ONE 2016, 11, e0165386.

349. Lin, W. L.; Guu, S. Y.; Tsai, C. C.; Prakash, E.; Viswaraman, M.; Chen, H. B.; et al. Derivation of Cinnamon Blocks Leukocyte Attachment by Interacting with Sialosides. PLoS One 2015, 10, e0130389.

350. Gruenwald, J.; Freder, J.; Armbruester, N. Cinnamon and health. Crit. Rev. Food Sci. Nutr. 2010, 50, 822-834.

351. Hong, K. J.; Lee, H. S.; Kim, Y. S.; Kim, S. S. Ingenol protects human T cells from HIV-1 infection. Public Health Res. Perspect 2011, 2, 109-114.

352. Hasler, C. M.; Acs, G.; Blumberg, P. M. Specific binding to protein kinase C by ingenol and its induction of biological responses. Cancer Res. 1992, 52, 202-208.

353. Sorg, B.; Hecker, E.; Zur, C. D. Ingenols, II. On the chemistry of ingenol ii. Esters of ingenol and delta ${ }^{7,8}$-isoingenol. Z Naturforsch 1982, 37b, 748-756.

354. Ireland, D. C.; Wang, C. K. L.; Wilson, J. A.; Gustafson, K. R.; Craik, D. J. Cyclotides as Natural Anti-HIV Agents. Peptide Science 2007, 90.

355. Ireland, D. C.; Clark, R. J.; Daly, N. L.; Craik, D. J. Isolation, Sequencing, and Structure-Activity Relationships of Cyclotides. J. Nat. Prod. 2010, 73, 1610-1622.

356. Kapewangolo, P.; Hussein, A. A.; Meyer, D. Inhibition of HIV-1 enzymes, antioxidant and anti-inflammatory activities of Plectranthus barbatus. Journal of Ethnopharmacology 2013.

357. Lukhoba, C. W.; Simmonds, M. S. J.; Paton, A. J. Plectranthus: a review of ethnobotanical uses. Journal of Ethnopharmacology 2006, 103, 1-24.

358. Kongkathip, B.; Kongkathip, N.; Sunthitikawinsakul, A.; Napaswat, C.; Yoosook, C. Anti-HIV-1 Constituents from Clausena excavata: Part II. Carbazoles and a Pyranocoumarin. Phytother. Res. 2005, 19, 728-731.

359. Ruangrungsi, N.; Ariyaprayoon, J.; Lange, G. L.; Organ, M. G. Three new carbazole alkaloids isolated from Murraya siamensis. J. Nat. Prod. 1990, 53, 946-952.

360. Lo, W. L.; Wu, C. C.; Chang, F. R.; Wang, W. Y.; Khalil, A. T.; Lee, K. H.; Wu, Y. C. Antiplatelet and anti-HIV constituents from Euchresta formosana. Natural Product Research 2003, 17, 91-97.

361. Lo, W. L.; Chang, F. R.; Liaw, C. C.; Wu, Y. C. Cytotoxic coumaronochromones from the roots of Euchresta formosana. Planta Med. 2002, 68, 146-151.

362. Nageswara, R. K.; Srimannarayana, G. Flemiphyllin, an isoflavone from stems of Flemingia macrophylla. Phytochemistry 1984, 23, 927-929.

363. Mizuno, M.; Tamura, K. I.; Tanaka, T.; Iinuma, M. Three prenylflavanones from Euchresta japonica. Phytochemistry 1988, 27, 1831-1834.

364. Wintola, O. A.; Afolayan, A. J. Alepidea amatymbica Eckl. \& Zeyh.: A Review of Its Traditional Uses, Phytochemistry, Pharmacology, and Toxicology. Evidence-Based Complementary and Alternative Medicine 2014.

365. Lubbe, A.; Seibert, I.; Klimkait, T.; Kooy, F. V. D. Ethnopharmacology in overdrive: The remarkable anti-HIV activity of Artemisia annua. Journal of Ethnopharmacology 2012, 141, 854-859. 
366. Oh, C. S.; Price, J.; Brindley, M. A.; Widrlechner, M. P.; Qu, L.; Coy, J.-A. M.; Murphy, P.; Hauck, C.; Maury, W. Inhibition of HIV-1 infection by aqueous extracts of Prunella vulgaris L. Virology Journal 2011, 8, 188.

367. Saida, M. S.; Chinchansurea, A. A.; Nawaleb, L.; Durgec, A.; Wadhwanic, A.; Kulkarnic, S. S.; Sarkarb, D.; Joshia, S. P. A new butenolide cinnamate and other biological active chemical constituents from Polygonum glabrum. Natural Product Research 2015.

368. Sakurai, N.; Wu, J. H.; Sashida, Y.; Mimaki, Y.; Nikaido, T.; Koike, K.; Itokawa, H.; Lee, K. H. Anti-AIDS agents. Part 57: Actein, an anti-HIV principle from the rhizome of Cimicifuga racemosa (black cohosh), and the anti-HIV activity of related saponins. Bioorg. E Med. Chem. Lett. 2004, 14, 1329-1332.

369. Tai, B. H.; Nhut, N. D.; Nhiem, N. X.; Quang, T. H.; Ngan, N. T. T.; Luyen, B. T. T.; Huong, T. T. Jennifer Wilson, John A. Beutler, Ninh Khac Ban, Nguyen Manh Cuong, and Young Ho Kim, An evaluation of the RNase H inhibitory effects of Vietnamese medicinal plant extracts and natural compounds. Pharmaceutical Biology 2011, 49, 1046-1051.

370. Wu, P. L.; Su, G. C.; Wu, T. S. Constituents from the Stems of Aristolochia manshuriensis. J. Nat. Prod. 2003, 66, 996-998.

371. Wu, T. S.; Leu, Y. L.; Chan, Y. Y. Constituents from the stem and root of Aristolochia kaempferi. Biol. Pharm. Bull. 2000, 23, 1216-1219.

372. Nakanishi, T.; Iwasak, K.; Nasu, M.; Miura, I.; Yoneda, K. Aristoloside, an aristolochic acid derivative from stems of Aristolochia manshuriensis. Phytochemistry 1982, 21, 1759-1762.

373. Wu, T. S.; Kao, M. S.; Wu, P. L.; Lin, F. W.; Shi, L. S.; Teng, C. M. The heartwood constituents of Tetradium glabrifolium. Phytochemistry 1995, 40, 121-124.

374. Wu, T. S.; Tsai, Y. L.; Wu, P. L.; Lin, F. W.; Lin, J. K. Constituents from the leaves of Aristolochia elegans. J. Nat. Prod. 2000, 63, 692-693.

375. Wu, X. D.; Cheng, J. T.; He, J.; Zhang, X. J.; Dong, L. B.; Gong, X.; Song, L. D.; Zheng, Y. T.; Peng, L. Y.; Zhao, Q. S. Benzophenone glycosides and epicatechin derivatives from Malania oleifera. Fitoterpia 2012, 83, 1068-1071.

376. Wu, S. Y.; Fu, Y. H.; Zhou, Q.; Bai, M.; Chen, G. Y.; Han, C. R.; Song, X. P. Biologically active oligostilbenes from the stems of Vatica mangachapoi and chemotaxonomic significance. Natural Product research 2018.

377. Hakim, E. H.; Juliawaty, L. D.; Syah, Y. M.; Din, L. B.; Ghisalberti, E. L.; Latip, J.; Achmad, S. A. Cytotoxic properties of oligostilbenoids from the tree barks of Hopea dryobalanoides. Z Naturforsch C 2005, 60, 723-727.

378. Patra, A.; Dey, A. K.; Kundu, A. B.; Saraswathy, A.; Purushothaman, K. K. Shoreaphenol, a polyphenol from Shorea robusta. Phytochemistry 1992, 31, 2561-2562.

379. Yan, K. X.; Terashima, K.; Takaya, Y.; Niwa, M. Two new stilbenetetramers from the stem of Vitis vinifera 'Kyohou'. Tetrahedron. 2002, 58, 6931-6935.

380. Yang, G. X.; Zhou, J. T.; Li, Y. Z.; Hu, C. Q. Anti-HIV bioactive stilbene dimers of Caragana rosea. Planta Med. 2005, 71, 569-571.

381. Zofou, D.; Kang, F. N.; Sippl, W.; Efange, S. M. N. Bioactive natural products derived from the central African flora against neglected tropical diseases and HIV. Nat. Prod. Rep. 2013.

382. Mahwasane, S. T.; Middleton, L.; Boaduo, N. An ethnobotanical survey of indigenous knowledge on medicinal plants used by the traditional healers of the Lwamondo area, Limpopo province, South Africa. South African Journal of Botany 2013, 88, 69-75.

383. Lagrota, M. H. C.; Wigg, M. D.; Santos, M. M. G.; Miranda, M. M. F. S.; Camara, F. P.; Couceiro, J. N. S. S.; Costa, S. S. Inhibitory activity of extracts of Alternanthera brasiliana (Amaranthaceae) against the herpes simplex virus. Phytother. Res. 1994, 8, 358-361.

384. Wang, H. X.; Ng, T. B. Examination of lectins, polysaccharopeptide, polysaccharide, alkaloid, coumarin and trypsin inhibitors for inhibitory activity against human immunodeficiency virus reverse transcriptase and glycohydrolases. Planta Med. 2001, 67, 669-672.

385. Thiagarajan, V. R. K.; Shanmugam, P.; Krishnan, U. M.; Muthuraman, A.; Singh, N. Ameliorative potential of Butea monosperma on chronic constriction injury of sciatic nerve induced neuropathic pain in rats. An. Acad. Bras. Cienc. 2012, 84.

386. Kashiwada, Y.; Wang, H.-K.; Nagao, T.; Kitanaka, S.; Yasuda, I.; Fujioka, T.; Yamagishi, T.; Cosentino, L. M.; Kozuka, M.; Okabe, H. Anti-AIDS agents. 30. Anti-HIV activity of oleanolic acid, pomolic acid, and structurally related triterpenoids. J. Nat. Prod. 1998, 61, 1090-1095.

387. Lam, T. L.; Lam, M. L.; Au, T. K.; Ip, D. T.; Ng, T. B.; Fong, W. P.; Wan, D. C. A comparison of human immunodeficiency virus type-1 protease inhibition activities by the aqueous and methanol extracts of Chinese medicinal herbs. Life Sci. 2000, 67, 2889-2896.

388. Abdel-Malek, S.; Bastien, J. W.; Mahler, W. F.; Jia, Q.; Reinecke, M. G.; Robinson, W. E.; Shu, Y.-H.; Zalles-Asin, J. Drug leads from the Kallawaya herbalists of Bolivia. 1. Background, rationale, protocol and anti-HIV activity. J. Ethnopharmacol. 1996, 50, 157-166. 
389. Pengsuparp, T.; Cai, L.; Constant, H.; Fong, H. H. S.; Lin, L. Z.; Kinghorn, A. D.; Pezzuto, J. M.; Cordell, G. A.; Ingolfsdóttir, K.; Wagner, H. Mechanistic evaluation of new plant-derived compounds that inhibit HIV-1 reverse transcriptase. J. Nat. Prod. 1995, 58, 1024-1031.

390. Luthra, P. M.; Singh, R.; Chandra, R. Therapeutic uses of Curcuma longa (Turmeric). Indian Journal of Clinical Biochemist. 2001, 16, 153-160.

391. Min, B. S.; Bae, K. H.; Kim, Y. H.; Miyashiro, H.; Hattori, M.; Shimotohno, K. Screening of Korean plants against human immunodeficiency virus type 1 protease. Phytother. Res. 1999, 13, 680-682.

392. Ali, H.; Konig, G. M.; Khalid, S. A.; Wright, A. D.; Kaminsky, R. Evaluation of selected sudanese medicinal plants for their in vitro activity against hemoflagellates, selected bacteria, HIV-1-RT and tyrosine kinase inhibitory, and for cytotoxicity. J. Ethnopharmacol. 2002, 83, 219-228.

393. Wu, N.; Wang, L.; Chzn, Y. K.; Liao, Z.; Yang, G. Y.; Hu, Q. F. Lignans from the stem of Styrax japonica. Asian J. Chem. 2011, 23, 931-932.

394. Chang, Y. S.; Woo, E. R. Korean medicinal plants inhibiting to human immunodeficiency virus type 1 (HIV-1) fusion. Phytother. Res. 2003, 17, 426-429.

395. Rukunga, G. M.; Kofi-Tsekpo, M. W.; Kurokawa, M.; Kageyama, S.; Mungai, G. M.; Muli, J. M.; Tolo, F. M.; Kibaya, R. M.; Muthaura, C. N.; Kanyara, J. N. Evaluation of the HIV-1 reverse transcriptase inhibitory properties of extracts from some medicinal plants in Kenya. Afr. J. Health Sci. 2002, 9, 81-90.

396. Kusumoto, I. T.; Nakabayashi, T.; Kida, H.; Miyashiro, H.; Hattori, M.; Namba, T.; Shimotohno, K. Screening of various plant-extracts used in ayurvedic medicine for inhibitory effects on human-immunodeficiency-virus type-1 (HIV-1) protease. Phytother. Res. 1995, 9, 180-184.

397. Sookkongwaree, K.; Geitmann, M.; Roengsumran, S.; Petsom, A.; Danielson, U. H. Inhibition of viral proteases by Zingiberaceae extracts and flavones isolated from Kaempferia parviflora. Pharmazie 2006, 61, 717-721.

398. Mujovo, S.; Hussein, A.; Meyer, J. J. M.; Fourie, B.; MutHIVhi, T.; Lall, N. Bioactive compounds from Lippia javanica and Hoslundia opposita. Nat. Prod. Res. 2008, 22, 1047-1054.

399. Piacente, S.; Pizza, C.; De Tommasi, N.; Mahmood, N. Constituents of Ardisia japonica and their in vitro anti-HIV activity. J. Nat. Prod. 1996, 59, 565-569.

400. Silprasit, K.; Seetaha, S.; Pongsanarakul, P.; Hannongbua, S.; Choowongkomon, K. Anti-HIV-1 reverse transcriptase activities of hexane extracts from some Asian medicinal plants. J. Med. Plants Res. 2011, 5, 4194-4201.

401. Maroyi, A. Ximenia caffra Sond. (Ximeniaceae) in sub-Saharan Africa: A synthesis and review of its medicinal potential. J. Ethnopharmacol. 2016, 184, 81-100.

402. Thomford, N. E.; Awortwe, C.; Dzobo, K.; Adu, F.; Chopera, D.; Wonkam, A.; Skelton, M.; Blackhurst, D.; Dandara, C. Inhibition of CYP2B6 by medicinal plant extracts: Implication for use of efavirenz and nevirapine based highly active anti-retroviral therapy (HAART) in resource-limited settings. Molecules 2016, 21, 211.

403. Eid, A. M. M.; Elmarzugi, N. A.; El-Enshasy, H. A. A review on the phytopharmacological effect of Swietenia macrophylla. Int. J. Pharm. Pharm. Sci. 2013, 5, 47-53.

404. Hasegawa, H.; Matsumiya, S.; Uchiyama, M.; Kurokawa, T.; Inouye, Y.; Kasai, R.; Ishibashi, S.; Yamasaki, $\mathrm{K}$. Inhibitory effect of some triterpenoid saponins on glucose transport in tumor cells and its application to in vitro cytotoxic and antiviral activities. Planta Med. 1994, 60, 240-243.

405. Xu, H.-X.; Wan, M.; Loh, B.-N.; Kon, O.-L.; Chow, P.-W.; Sim, K.-Y. Screening of traditional medicines for their inhibitory activity against HIV-1 protease. Phytother. Res. 1996, 10, 207-210.

406. Grzybek, J.; Wongpanich, V.; Mata-Greenwood, E.; Angerhofer, C. K.; Pezzuto, J. M.; Cordell, G. A. Biological evaluation of selected plants from Poland. Pharm. Biol. 1997, 35, 1-5.

407. Bedoya, L. M.; Sanchez-Palomino, S.; Abad, M. J.; Bermejo, P.; Alcami, J. Anti-HIV activity of medicinal plant extracts. J. Ethnopharmacol. 2001, 77, 113-116.

408. Birt, D. F.; Widrlechner, M. P.; Hammer, K. D. P.; Hillwig, M. L.; Wei, J.; Kraus, G. A.; Murphy, P. A.; McCoy, J. A.; Wurtele, E. S.; Neighbors, J. D. Hypericum in infection: Identification of anti-viral and anti-inflammatory constituents. Pharm. Biol. 2009, 47, 774-782.

409. Zhang, L.; Luo, R.-H.; Wang, F.; Jiang, M.-Y.; Dong, Z.-J.; Yang, L.-M.; Zheng, Y.-T.; Liu, J.-K. Highly functionalized daphnane diterpenoids from Trigonostemon thyrsoideum. Organ. Lett. 2010, 12, 152-155.

410. Chen, J. C.; Zhang, G. H.; Zhang, Z. Q.; Qiu, M. H.; Zheng, Y. T.; Yang, L. M.; Yu, K. B. Octanorcucurbitane and cucurbitane triterpenoids from the tubers of Hemsleya endecaphylla with HIV-1inhibitory activity. J.Nat. Prod. 2008, 71, 153-155.

411. Magadula, J. J.; Tewtrakul, S. Anti-HIV-1 protease activities of crude extracts of some Garcinia species growing in Tanzania. Afr. J. Biotechnol. 2010, 9, 1848-1852. 
412. Au, T. K.; Lam, T. L.; Ng, T. B.; Fong, W. P.; Wan, D. C. C. A Comparison of HIV-1 Integrase Inhibition by Aqueous and Methanol Extracts of Chinese Medicinal Herbs. Life Sci. 2001, 68, 1687-1694.

413. Ngwira, K. J.; Maharaj, V. J.; Mgani, Q. A. In vitro antiplasmodial and HIV-1 neutralization activities of root and leaf extracts from Berberis holstii. J. Herb. Med. 2015, 5, 30-35.

414. Louvel, S.; Moodley, N.; Seibert, I.; Steenkamp, P.; Nthambeleni, R.; Vidal, V.; Maharaj, V.; Klimkait, T. Identification of compounds from the plant species Alepidea amatymbica active against HIV. S. Afr. J. Bot. 2013, 86, 9-14.

415. Woradulayapinij, W.; Soonthornchareonnon, N.; Wiwat, C. In vitro HIV type 1 reverse transcriptase inhibitory activities of Thai medicinal plants and Canna indica L. rhizomes. J. Ethnopharmacol. 2005, 101, $84-89$.

416. Xiao, W. L.; Pu, J. X.; Chang, Y.; Li, X. L.; Huang, S. X.; Yang, L. M.; Li, L. M.; Lu, Y.; Zheng, Y. T.; Li, R. T. Sphenadilactones A and B, two novel nortriterpenoids from Schisandra sphenanthera. Organ. Lett. 2006, 8, 1475-1478.

417. Voravuthikunchai, S. P.; Phongpaichit, S.; Subhadhirasakul, S. Evaluation of antibacterial activities of medicinal plants widely used among AIDS patients in Thailand. Pharm. Biol. 2005, 43, 701-706.

418. Chinsembu, K. C. Ethnobotanical study of plants used in the management of HIV/AIDS-related diseases in Livingstone, Southern Province, Zambia. J. Evid.-Based Complement. Altern. Med. 2016.

419. Zhang, H. J.; Tan, G. T.; Hoang, V. D.; Hung, N. V.; Cuong, N. M.; Soejarto, D. D.; Pezzuto, J. M.; Fong, H. H. S. Natural anti-HIV agents. Part 2: Litseaverticillol a, a prototypic litseane sesquiterpene from Litsea verticillata. Tetrahedron Lett. 2001, 42, 8587-8591.

420. Esposito, F.; Carli, I.; Del Vecchio, C.; Xu, L.; Corona, A.; Grandi, N.; Piano, D.; Maccioni, E.; Distinto, S.; Parolin, C. Sennoside a, derived from the traditional Chinese medicine plant Rheum L., is a new dual HIV-1 inhibitor effective on HIV-1 replication. Phytomedicine 2016, 23, 1383-1391.

421. Chang, C. W.; Lin, M. T.; Lee, S. S.; Liu, K. C. S. C.; Hsu, F. L.; Lin, J. Y. Differential inhibition of reverse transcriptase and cellular DNA polymerase- $\alpha$ activities by lignans isolated from Chinese herbs, Phyllanthus myrtifolius Moon, and tannins from Lonicera japonica Thunb and Castanopsis hystrix. Antivir. Res. 1995, 27, 367-374.

422. Bessong, P. O.; Rojas, L. B.; Obi, L. C.; Tshisikawe, P. M.; Igunbor, E. O. Further screening of venda medicinal plants for activity against HIV type 1 reverse transcriptase and integrase. Afr. J. Biotechnol. 2006, 5, 526-528.

423. Asres, K.; Bucar, F.; Kartnig, T.; Witvrouw, M.; Pannecouque, C.; De Clercq, E. Antiviral activity against human immunodeficiency virus type 1 (HIV-1) and type 2 (HIV-2) of ethnobotanically selected Ethiopian medicinal plants. Phytother. Res. 2001, 15, 62-69. 